ORP-56291

Revision 0

\title{
Final Report - Glass Formulation Testing to Increase Sulfate Volatilization from Melter, VSL-04R4970-1, Rev. 0, dated 2/24/05
}

Prepared for the U.S. Department of Energy

Assistant Secretary for Environmental Management

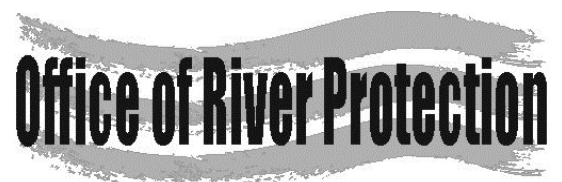

P.O. Box 450

Richland, Washington 99352 
ORP-56291

Revision 0

\section{Final Report - Glass Formulation Testing to Increase Sulfate Volatilization from Melter, VSL-04R4970-1, Rev. 0, dated 2/24/05}

A. A. Kruger

Department of Energy - Office of River Protection

K. S. Matlack

The Catholic University of America
I. L. Pegg

The Catholic University of America

W. Gong

The Catholic University of America

Date Published

June 2013

Prepared for the U.S. Department of Energy

Assistant Secretary for Environmental Management

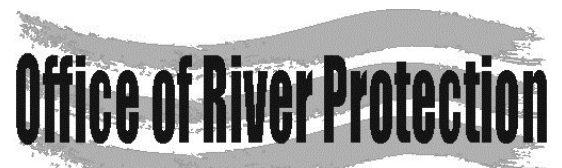

P.O. Box 450

Richland, Washington 99352

\section{APPROVED}

By Shauna Adams at 10:47 am, Nov 13, 2013

Release Approval

Date 
ORP-56291

Revision 0

TRADEMARK DISCLAIMER

Reference herein to any specific commercial product, process, or service by tradename, trademark, manufacturer, or otherwise, does not necessarily constitute or imply its endorsement, recommendation, or favoring by the United States Government or any agency thereof or its contractors or subcontractors.

This report has been reproduced from the best available copy.

Printed in the United States of America 


\section{Final Report}

Glass Formulation Testing to Increase Sulfate Volatilization from Melter

prepared by

Keith S. Matlack, Weiliang Gong, and Ian L. Pegg

Vitreous State Laboratory

The Catholic University of America

Washington, DC 20064

for

Duratek, Inc.

and

Department of Energy

Office of River Protection

October 15, 2004

Rev. 0; 2/24/05 
The Catholic University of America Vitreous State Laboratory
Glass Formulation Testing to Increase Sulfate Volatilization Final Report, VSL-04R4970-1, Rev. 0
Document Title:

Document Number and Revision:

Issue Date:
Glass Formulation Testing to Increase Sulfate Volatilization from Melter

VSL-04R4970-1, Rev. 0

$2 / 24 / 05$

Performing Organization: Vitreous State Laboratory, The Catholic University of America

Test Plan: $\quad$ Glass Formulation Testing to Increase Sulfate Volatilization from Melter VSL-03T4970-1, Rev. 0

This report describes the results of testing specified by the above Test Plan. The work was performed in compliance with the quality assurance requirements specified in the Test Plan. Results required by the Test Plan are reported. The test results and this report have been reviewed for correctness, technical adequacy, completeness, and accuracy.

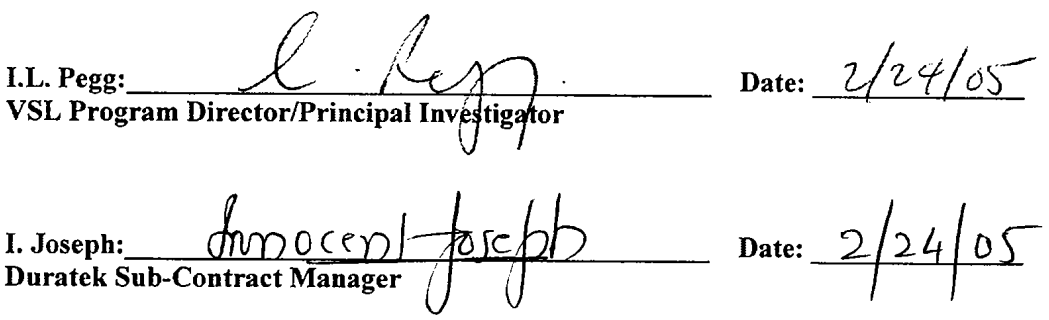


The Catholic University of America Vitreous State Laboratory
Glass Formulation Testing to Increase Sulfate Volatilization Final Report, VSL-04R4970-1, Rev. 0

\section{TABLE OF CONTENTS}

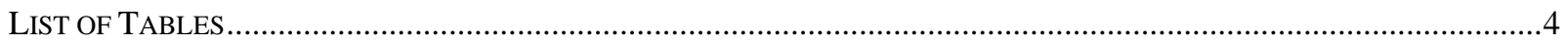

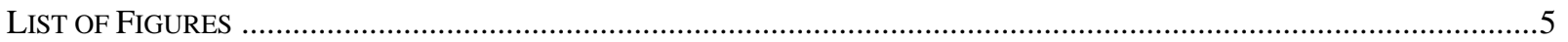

LIST OF ABBREVIATIONS ………...........................................................................................................

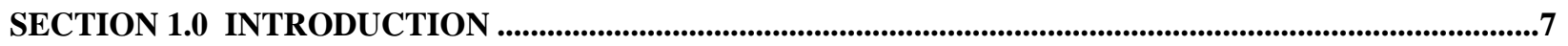

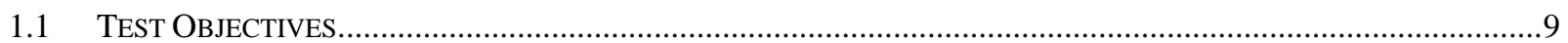

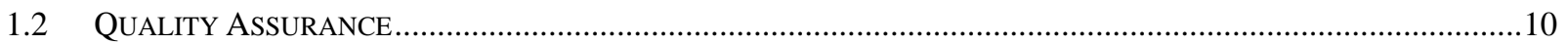

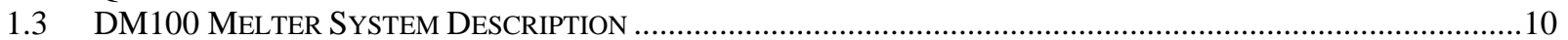

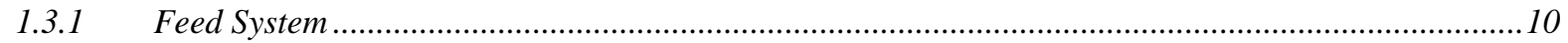

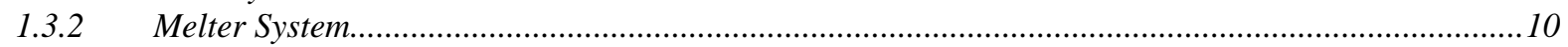

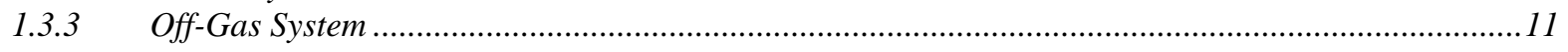

SECTION 2.0 WASTE SIMULANT AND GLASS FORMULATIONS .........................................................12

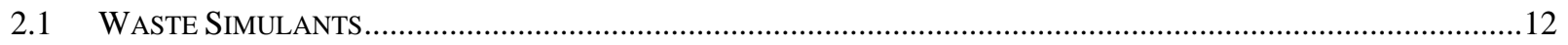

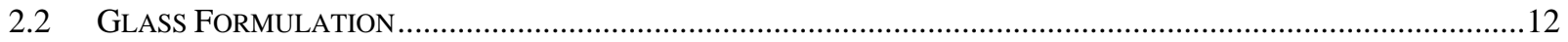

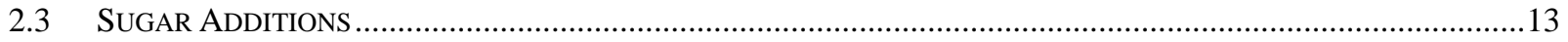

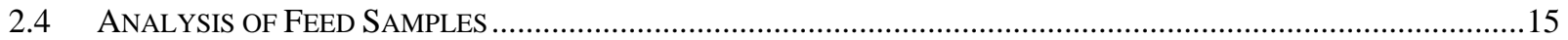

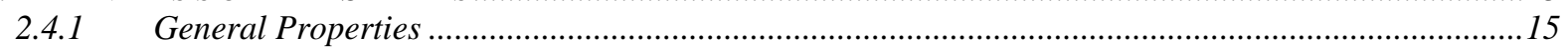

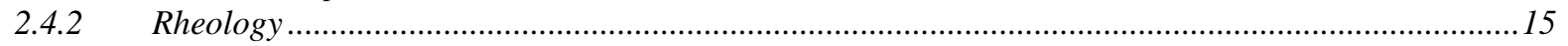

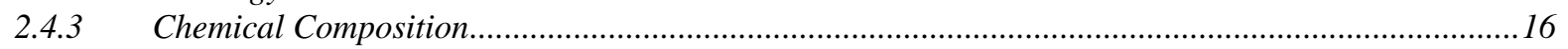

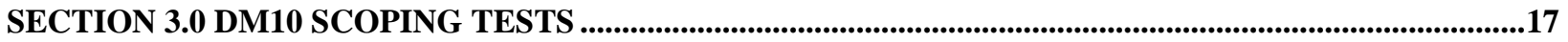

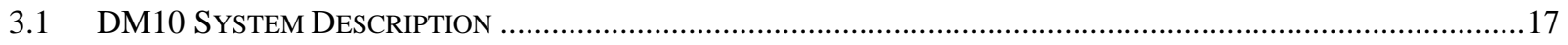

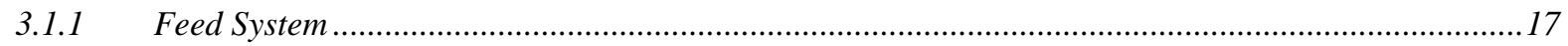

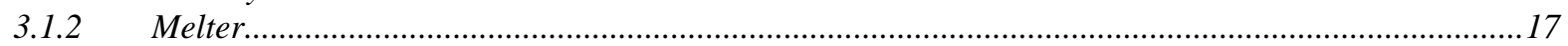

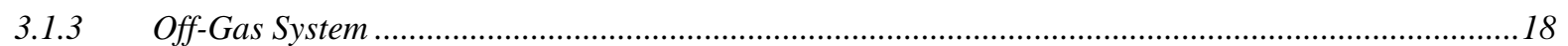

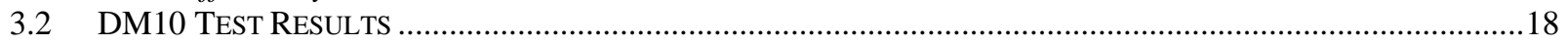

3.3 FINAL EVALUATION OF REDUCTANTS SELECTED FROM DM10 TESTS ..............................................................19

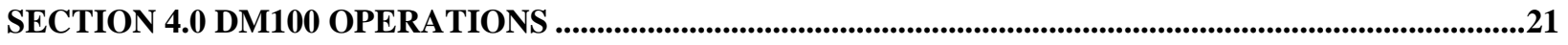

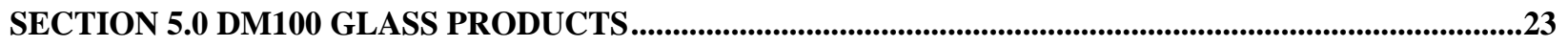

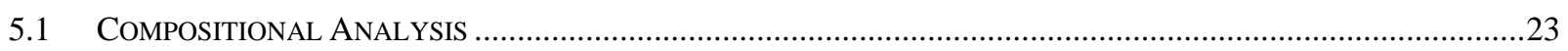

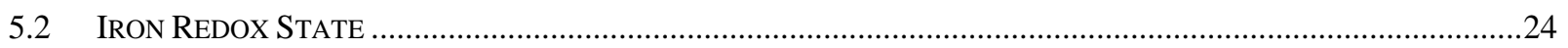

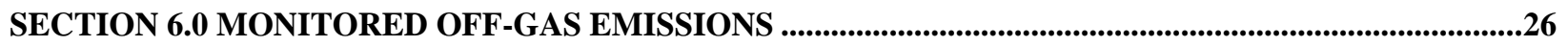

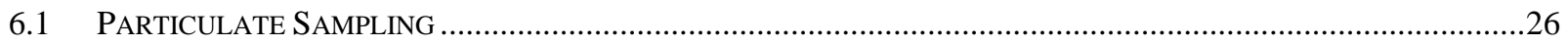

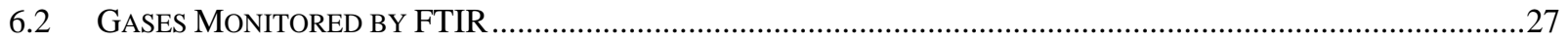

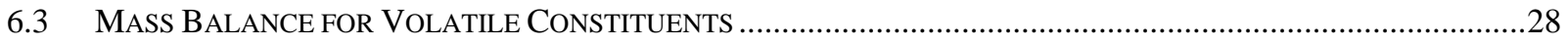

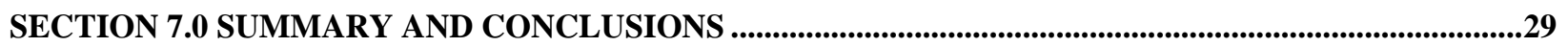

SECTION 8.0 RECOMMENDATIONS FOR FUTURE WORK ..................................................................30

SECTION 9.0 REFERENCES ................................................................................................................................... 
The Catholic University of America Vitreous State Laboratory
Glass Formulation Testing to Increase Sulfate Volatilization

Final Report, VSL-04R4970-1, Rev. 0

\section{List of Tables}

Page

Table 2.1. $\quad$ LAW Sub-Envelope A1 Simulant Recipe at 8 Molar Sodium used in DM10 Tests

$\mathrm{T}-1$

LAW Envelope A (AN-105) Waste Simulant Recipe at 8 Molar Sodium

Oxide Composition of LAW Sub-Envelope A1 Simulant and Corresponding

Glass Compositions

\section{Table 2.3.}

Table 2.4.

Glass Forming Additives for 1 Liter of Simulant (8 M Na) and Corresponding

Melter Feed Properties

Table 2.5.

Table 2.6.

Table 2.7.

Table 3.1.

Table 3.2.

Table 4.1.

Table 4.2.

Table 5.1.

Table 5.2.

Table 5.3.

Table 5.4.

Table 5.5.

Table 6.1.

Table 6.2.

Table 6.3.

Table 6.4.

Table 6.5.
Measured Properties of Crucible Glasses

Properties of Feed Samples from DM100 Melter Tests

XRF Analyzed Composition for Melter Feed Samples (wt\%)

Summary of DM10 Test Conditions and Results

Listing of DM10 Glasses Discharged, Masses, and Analysis Performed

Summary of DM100 Test Conditions and Results

Summary of Measured DM100 Parameters

Listing of DM100 Glasses Discharged, Masses, and Analysis Performed

XRF Analyzed Composition for DM100 Discharged Glass Samples (wt\%)

Comparison of XRF and DCP Analysis of Melter Glass Samples (wt\%)

XRF Analyzed Glass Compositions for DM100 Dip Samples (wt\%)

Glass Redox for Selected Glass Samples

Results from Melter Off-Gas Emission Samples

Average Concentration (ppmv) of Selected Species in Off-Gas Measured

by FTIR Spectroscopy during DM100 Tests

Concentration Ranges (ppmv) of Selected Species in Off-Gas Measured

by FTIR Spectroscopy during DM100 tests

Average NOx Fluxes in Off-Gas Measured by FTIR Spectroscopy

Mass Balance for Sulfur, Iodine and Selenium during DM100 tests

with LAW Sub-Envelope A1 Simulants (\% of Feed)
$\mathrm{T}-2$

$\mathrm{T}-3$

T-4

$\mathrm{T}-5$

T-6

T-7

T-8

T-10

T-14

T-15

T-16

T-19

T-24

T-25

T-26

T-27

T-29

T-30

T-31

T-32 
The Catholic University of America

Vitreous State Laboratory
Glass Formulation Testing to Increase Sulfate Volatilization

Final Report, VSL-04R4970-1, Rev. 0

\section{List of Figures}

Figure 1.1.

Figure 1.2(a)

Figure 1.2(b)

Figure 1.2(c)

Figure 2.1.

Figure 2.2.

Figure 3.1

Figure 3.2

Figure 3.3

Figure 3.4

Figure 4.1.a.

Figure 4.1.b.

Figure 4.1.c.

Figure 4.2.a.

Figure 4.2.b.

Figure 4.2.c.

Figure 4.3.a.

Figure 4.3.b.

Figure 4.3.c. Figure 4.4.a.

Figure 4.4.b.

Figure 4.4.c.

Figure 5.1.

Figure 5.2.

Figure 5.3.

Figure 5.4.

Figure 6.1.a.

Figure 6.1.b.

Figure 6.1.c.

Figure 6.2.a. Figure 6.2.b.

Figure 6.2.c. Figure 6.3.a. Figure 6.3.b.

Figure 6.3.c.
Schematic diagram of DuraMelter 100-WV vitrification system

Cross-section through the DM100-WV melter-Plan View

Cross-section through the DM100-WV melter-Section AA

Cross-section through the DM100-WV melter-Section CC

Measured Viscosity of LAW A melter feed samples

Comparison of measured feed rheology with proposed WTP bounds

(bounds from WTP-RPT-075, Rev. 0, Feb. 2003)

XRF analysis of sulfur in DM10 product glasses for tests with sugar and urea

XRF analysis of sulfur in DM10 product glasses for tests with starch and PEG

XRF analysis of iodine in DM10 product glasses for tests with sugar and urea

XRF analysis of iodine in DM10 product glasses for tests with starch and PEG

Glass production rate for the DM100 Urea and Sugar Test

Glass production rate for the DM100 Vanadium Additive Test

Glass production rate for the DM100 Starch and Sugar Test

Glass temperatures and electrode power for the DM100 Urea and Sugar Test

Glass temperatures and electrode power for the DM100 Vanadium

Additive Test

Page

Plenum temperatures and electrode power for the DM100 Urea and Sugar Test F-17

Plenum temperatures and electrode power for the DM100 Vanadium

Additive Test

F-18

Plenum temperatures and electrode power for the DM100 Starch and Sugar Test F-19

Electrode temperatures and power for the DM100 Urea and Sugar Test $\quad$ F-20

Electrode temperatures and power for the DM100 Vanadium Additive Test $\quad$ F-21

Electrode temperatures and power for the DM100 Starch and Sugar Test $\quad$ F-22

XRF analysis of $\mathrm{Na}_{2} \mathrm{O}$ and $\mathrm{SiO}_{2}$ in DM100 product glasses $\quad$ F-23

XRF analysis of select major oxides in DM100 product glasses $\quad$ F-24

XRF analysis of spiked oxides in DM100 product glasses $\quad$ F-25

XRF analysis of chlorine and sulfur in DM100 product glasses $\quad$ F-26

Nitrogen oxide concentrations in off-gas from FTIR for the DM100 Urea

and Sugar Test

F-27

Nitrogen oxide concentrations in off-gas from FTIR for the DM100

Vanadium Additive Test

F-28

Nitrogen oxide concentrations in off-gas from FTIR for the DM100 Starch

and Sugar Test

F-29

F-30

CO concentrations in off-gas from FTIR for the DM100 Vanadium

Additive Test

F-31

CO concentrations in off-gas from FTIR for the DM100 Starch and Sugar Test F-32

$\mathrm{NH}_{3}$ concentrations in off-gas from FTIR for the DM100 Urea and Sugar Test F-33

$\mathrm{NH}_{3}$ concentrations in off-gas from FTIR for the DM100 Vanadium

Additive Test

F-34

$\mathrm{NH}_{3}$ concentrations in off-gas from FTIR for the DM100 Starch and Sugar Test F-35 
The Catholic University of America Vitreous State Laboratory
Glass Formulation Testing to Increase Sulfate Volatilization Final Report, VSL-04R4970-1, Rev. 0

\section{List of Abbreviations}

$\begin{array}{ll}\text { AA } & \text { Atomic Absorption Spectroscopy } \\ \text { ADS } & \text { Air Displacement Slurry } \\ \text { DCP-AES } & \text { Direct Current Plasma Atomic Emission Spectroscopy } \\ \text { DF } & \text { Decontamination Factor } \\ \text { DM } & \text { DuraMelter } \\ \text { DOE } & \text { Department of Energy } \\ \text { EPA } & \text { Environmental Protection Agency } \\ \text { FTIR } & \text { Fourier Transform Infrared Spectroscopy } \\ \text { GC } & \text { Gas Chromatography } \\ \text { HEPA } & \text { High-Efficiency Particulate Air Filter } \\ \text { HLW } & \text { High Level Waste } \\ \text { IC } & \text { Ion Chromatography } \\ \text { LAW } & \text { Low Activity Waste } \\ \text { M } & \text { Molarity } \\ \text { N } & \text { Normality } \\ \text { ORP } & \text { Office of River Protection } \\ \text { PEG } & \text { Polyethylene Glycol } \\ \text { QA } & \text { Quality Assurance } \\ \text { QAPP } & \text { Quality Assurance Project Plan } \\ \text { QC } & \text { Quality Control } \\ \text { RPP } & \text { River Protection Project } \\ \text { VSL } & \text { Vitreous State Laboratory } \\ \text { WTP } & \text { Waste Treatment and Immobilization Plant } \\ \text { XRF } & \text { X-Ray Fluorescence } \\ & \end{array}$


The Catholic University of America Vitreous State Laboratory
Glass Formulation Testing to Increase Sulfate Volatilization

Final Report, VSL-04R4970-1, Rev. 0

\section{SECTION 1.0 INTRODUCTION}

About 50 million gallons of high-level mixed waste is currently in storage in underground tanks at The United States Department of Energy's (DOE's) Hanford site in the State of Washington. The Hanford Tank Waste Treatment Plant (WTP) will provide DOE's Office of River Protection (ORP) with a means of treating this waste by vitrification for subsequent disposal. The tank waste will be separated into low- and high-activity fractions, which will then be vitrified respectively into Immobilized Low Activity Waste (ILAW) and Immobilized High Level Waste (IHLW) products. The ILAW product will be disposed of in an engineered facility on the Hanford site while the IHLW product will be directed to the national deep geological disposal facility for high-level nuclear waste. The ILAW and IHLW products must meet a variety of requirements with respect to protection of the environment before they can be accepted for disposal.

The Office of River Protection is currently examining options to optimize the Low Activity Waste (LAW) facility and the LAW glass waste form. One option under evaluation is to enhance the waste processing rate of the vitrification plant currently under construction. It is likely that the capacity of the LAW vitrification plant can be increased incrementally by implementation of a variety of low-risk, high-probability changes, either separately or in combination. These changes include:

- Operating at the higher processing rates demonstrated at the LAW pilot melter

- Increasing the glass pool surface area within existing external melter envelope

- Increasing plant availability

- Increasing the glass waste loading

- Removing sulfate from the LAW stream

- Operating the melter at slightly higher temperature

- Installing the third LAW melter into the WTP plant

- Other smaller impact changes

The Vitreous State Laboratory at The Catholic University of America (VSL) and Duratek, Inc. are evaluating several of these potential incremental improvements for ORP in support of its evaluation of WTP LAW facility optimization [1]. The tests described in this report focus on development and testing of glass formulations to increase sulfate volatilization from the melter as a means to increase waste loading in the LAW glass products. Implementation of such an approach would require breaking the recycle loop for off-gas treatment streams in the current WTP flow-sheet. Previous testing at VSL and Duratek has shown that organics and certain inorganic components affect partitioning of sulfur to the off-gas [2-9]. Depending on their type, organics can react mainly in the cold-cap or can persist to higher temperatures such that they can significantly affect glass redox. The ideal additives would have a large effect on sulfur partitioning without significantly affecting glass redox. Excessive reduction of the glass melt is undesirable in the presence of sulfur because it can lead to precipitation of corrosive phases such as sulfides that deleteriously impact melter life. Data provided in this report show the effects of 
The Catholic University of America Vitreous State Laboratory
Glass Formulation Testing to Increase Sulfate Volatilization Final Report, VSL-04R4970-1, Rev. 0

various organics on sulfur partitioning, feed processing, glass redox, and LAW feed rheology. The effect of an inorganic glass former additive, vanadium, on sulfur partitioning was also investigated.

The Vitreous State Laboratory is also developing and testing glass formulations for WTP waste envelopes to provide data to meet the WTP contract requirements and to support system design activities [2]. That work is based upon small-scale batch melts ("crucible melts") using waste simulants. Selected formulations have also been tested in small-scale, continuously-fed, joule-heated melters (DM10 and DM100 systems) [3-9] and, ultimately, in the LAW Pilot Melter [10-16]. Such melter tests provide information on key process factors such as feed processing behavior, dynamic effects during processing, sulfate incorporation, processing rates, off-gas amounts and compositions, foaming control, etc., that cannot be reliably obtained from crucible melts. This sequential scale-up approach in the vitrification testing program ensures that maximum benefit is obtained from the more costly pilot-scale tests and that the most effective use is made of that resource. Consistent with that proven testing approach, the principal objective of the work reported here was to collect the necessary small-scale melter test data while varying the type and amount of feed additives. The present work was performed in accordance with a corresponding Test Plan that was prepared for ORP [17].

In view of the present recycle loop in the flow sheet, the current WTP strategy is to keep as much of the sulfur as possible in the LAW glass. As a result, partitioning of sulfur to the off-gas has not been investigated in detail for WTP LAW feeds. However, information from previous tests [2, 3, 5, 6-9] indicates that enhanced partitioning is a viable approach provided it can be accomplished without over-reducing the glass melt, which is essential to practical deployment. The tests reported here provide information on the effects of organic and inorganic additives on LAW sulfur partitioning and feed processing. Taking advantage of the increased partitioning of sulfur to the off-gas stream would lead to increases in waste loading, provided the current WTP recycle loop can be broken.

The tests described in this report utilized blended feed (glass formers plus waste simulant) prepared by Optima Chemicals according to VSL specifications. Sufficient feed was prepared to produce nearly seventeen hundred kilograms of glass. Reductants in the form of sugar, urea, starch, and polyethylene glycol (PEG) were added to the feed at ratios of between 0.5 to $1.25(0.5=1$ mole sucrose per 16 mole NOx or 3 mole carbon per 4 mole NOx). The DM10 was used to screen the four reductants at four stoichiometric ratios to determine which volatilized the most sulfur without overly reducing the iron in the glass. Subsequently, two 50-hour DM100 tests were conducted: one with urea and sugar at a stoichiometric ratio of 1.0 and the other with starch and sugar at a stoichiometric ratio of 0.75 , based on the DM10 results. Another 50-hour test was conducted using vanadium as an additive to determine the effect of this inorganic additive on sulfur volatility. The DM100-WV melter was used in order to provide a direct comparison with the LAW tests previously conducted on the same melter [3-9]. Key operating parameters such as glass temperature and production rate were held constant to investigate the effects of the compositional changes on feed and glass processing characteristics as well as sulfur volatility. The bubbling rate was adjusted to achieve a target glass production 
rate of $2000 \mathrm{~kg} / \mathrm{m}^{2} /$ day with a near-complete cold cap (90-100\% of melt surface covered with feed). Quantitative measurements of glass production rates, melter operating conditions (temperatures, pressures, power, flows, etc.), and off-gas characteristics ( $\mathrm{NOx}, \mathrm{SO}_{2}, \mathrm{CO}$, particulate load and composition, and acid gases) were made for each test.

\subsection{Test Objectives}

The principal objectives of the DM100 and DM10 tests were to determine the impact of four different organics and one inorganic feed additive on sulfate volatilization and to determine the sulfur partitioning between the glass and the off-gas system. The tests provided information on melter processing characteristics and off-gas data including sulfur incorporation and partitioning.

A series of DM10 and DM100 melter tests were conducted using a LAW Envelope A feed. The testing was divided into three parts. The first part involved a series of DM10 melter tests with four different organic feed additives: sugar, polyethylene glycol (PEG), starch, and urea. The second part involved two confirmatory 50-hour melter tests on the DM100 using the best combination of reductants and conditions based on the DM10 results. The third part was performed on the DM100 with feeds containing vanadium oxide $\left(\mathrm{V}_{2} \mathrm{O}_{5}\right)$ as an inorganic additive to increase sulfur partitioning to the off-gas. Although vanadium oxide is not a reductant, previous testing has shown that vanadium shows promise for partitioning sulfur to the melter exhaust $[3,18,19]$, presumably through its known catalytic effect on the $\mathrm{SO}_{2} / \mathrm{SO}_{3}$ reaction. Crucible-scale tests were conducted prior to the melter tests to confirm that the glasses and feeds would be processable in the melter and that the glasses would meet the waste form (ILAW) performance requirements.

Thus, the major objectives of these tests were to:

- Perform screening tests on the DM10 followed by tests on the DM100-WV system using a LAW -Envelope A feed with four organic additives to assess their impact on sulfur volatilization.

- Perform tests on the DM100-WV system using a LAW -Envelope A feed containing vanadium oxide to assess its impact on sulfur volatilization.

- $\quad$ Determine feed processability and product quality with the above additives.

- Collect melter emissions data to determine the effect of additives on sulfur partitioning and melter emissions.

- Collect and analyze discharged glass to determine sulfur retention in the glass. 
The Catholic University of America Vitreous State Laboratory
Glass Formulation Testing to Increase Sulfate Volatilization

Final Report, VSL-04R4970-1, Rev. 0

- Prepare and characterize feeds and glasses with the additives to confirm that the feeds and the glass melts are suitable for processing in the DM100 melter.

- Prepare and characterize glasses with the additives to confirm that the glasses meet the waste form (ILAW) performance requirements.

\subsection{Quality Assurance}

This work was conducted under a quality assurance program that is in place at the VSL that is based on NQA-1 (1989) and NQA-2a (1990) Part 2.7. This program is supplemented by a Quality Assurance Project Plan [20] for WTP work that is conducted at VSL. Test and procedure requirements by which the testing activities were planned and controlled are defined in the Test Plan [17]. The program is supported by VSL standard operating procedures that were used for this work [21]. The requirements of DOE/RW-0333P are not applicable to this work.

\subsection{DM100 Melter System Description}

\subsubsection{Feed System}

A schematic diagram of the DM100 vitrification system is shown in Figure 1.1. The melter feed is introduced in batches into a feed container that is mounted on a load cell for weight monitoring. The feed is stirred with a variable speed mixer and constantly recirculated except for periodic, momentary interruptions during which the weight is recorded. The way in which the feed is introduced into the melter is designed to mimic the operation of an ADS pump, which is the present WTP baseline. The recirculation loop extends to the top of the melter where feed is diverted from the recirculation loop into the melter through a Teflon-lined feed line and water-cooled feed tube. Two computer-operated pinch valves, one on the feed line and one on the recirculation loop, are activated in a timed sequence to introduce feed into the melter at the desired rate. The feed rate is regulated by adjusting the length of each pulse, the time between each pulse, and the pressure applied to the recirculation loop. A compressed air line is attached to the feed line and can be used to automatically clear the feed line into the melter after each pulse. The mixed feed enters the melter through a water-cooled, vertical feed tube.

\subsubsection{Melter System}

Cross-sectional diagrams through the DM100-WV melter are shown in Figures 1.2a-c. The DM100-WV unit is a ceramic refractory-lined melter fitted with a pair of opposing Inconel 690 plate electrodes as well as a bottom electrode. The melter can be operated with either three-phase or single-phase power. However, the standard mode of operation, which was used for these tests, is single-phase with voltage applied to the side electrodes only. The bubbler used for stirring the melt pool enters from the top and is removable. The glass product is removed 
The Catholic University of America Vitreous State Laboratory
Glass Formulation Testing to Increase Sulfate Volatilization

Final Report, VSL-04R4970-1, Rev. 0

from the melter by means of an air-lift discharge system. The DM100-WV has a melt surface of $12 \times 14$ inches, giving a melt surface area of $0.108 \mathrm{~m}^{2}$. The nominal depth of the melt pool is about 19 inches, which gives a typical glass inventory of between 115 and $120 \mathrm{~kg}$. The plenum height is 27.5 inches. Temperatures are monitored by means of a series of thermocouples located in the melt pool, the electrodes, the plenum space, and the discharge chamber.

\subsubsection{Off-Gas System}

For operational simplicity, the DM100-WV is equipped with a dry off-gas treatment system involving gas filtration operations only. Exhaust gases leave the melter plenum through a film cooler device that minimizes the formation of solid deposits. The film-cooler air has constant flow rate and its temperature is thermostatically controlled. Consequently, under steady-state operating conditions, the exhaust gases passing through the transition line (between the melter and the first filtration device) can be sampled at constant temperature and airflow rate. The geometry of the transition line conforms to the requirements of the 40-CFR-60 air sampling techniques. Immediately downstream of the transition line are cyclonic filters followed by conventional pre-filters and HEPA filters. The temperature of the cyclonic filters is maintained above $150^{\circ} \mathrm{C}$ while the temperatures in the HEPAs are kept sufficiently high to prevent moisture condensation. The entire train of gas filtration operations is duplicated and each train is used alternately. An induced draft fan completes the system. 
The Catholic University of America

Vitreous State Laboratory
Glass Formulation Testing to Increase Sulfate Volatilization

Final Report, VSL-04R4970-1, Rev. 0

\section{SECTION 2.0 \\ WASTE SIMULANT AND GLASS FORMULATIONS}

\subsection{Waste Simulants}

The Sub-Envelope A1 waste simulant used in previous tests on the DM100 [7] and DM1200 [22] was based on composition data for tank AN-105 (sup), derived from the TF COUP, Rev. 3 [23]. The composition has changed very little from the previous revision of the TF COUP [24] that was originally used to develop the glass formulation for this LAW feed. The organics data in the TF COUP were supplemented by other Hanford tank waste information [25]. Data from a sample characterization report [25] were used as the basis for the relative concentration of organics. These concentrations were then scaled up to match the total organic carbon (TOC) concentration given in TF COUP, Rev. 3 [23]. Subsequently, minor changes to the simulant composition were directed [26] which resulted in a decrease in TOC but little change in glass forming constituents $[17,27]$. The sodium concentration in the simulant was increased by $2.56 \%$ to account for sodium additions in pretreatment [2, 28]. No recyle is included in the present simulant because increased volatilization of sulfate from the melter would only be employed if the present recycle loop were broken. The nominal concentration, expressed in terms of the sodium molarity, was determined on the basis of melter feed rheology tests on similar formulations [29]. The results of those tests led to the selection of 8.0 molar sodium as the nominal simulant concentration for the LAW AN-105 waste. The waste simulant used in DM10 melter tests was based on the composition data for tank AN-105 derived from the TF COUP [23] and the waste simulant used in DM100 melter tests was based on the composition data provided in the WTP Test Specification [26]. The small differences in the waste compositions between these two data sources are not expected to have any significant effect on the behavior of the reductants evaluated in this study.

The nominal simulant formulations are given in Tables 2.1 and 2.2. The resulting simulant is a solution of predominantly sodium, aluminum, hydroxide, nitrate, and nitrite. Samples of the simulant were prepared according to Tables 2.1 and 2.2 and tested at VSL. For the melter tests, Optima Chemicals, which has supplied all of the LAW simulants for the previous DM100 and LAW Pilot Melter studies, prepared the simulant and added the glass forming chemicals before shipment to VSL in 55-gallon drums. Reductants in the form of sugar, urea, starch, and polyethylene glycol (PEG) were added at VSL.

\section{$2.2 \quad$ Glass Formulation}

The feed additives were selected on the basis of glass formulation studies, which included optimization with respect to sulfate incorporation and salt formation [2, 3, 4, 18], as well as rheological testing [29]. Based on these results, LAWA44 was developed for the Sub-Envelope A1, AN-105 waste. Table 2.3 shows the LAW Envelope A glass compositions used for the 
The Catholic University of America Vitreous State Laboratory
Glass Formulation Testing to Increase Sulfate Volatilization

Final Report, VSL-04R4970-1, Rev. 0

melter tests. The concentration of $\mathrm{SO}_{3}$ in this glass was increased to $0.5 \mathrm{wt} \%$ based on crucible studies and the need to have a high enough sulfur concentration to show the effects of the reductants on sulfur volatilization for the melter tests. The feed used in the DM10 and the DM100 starch and sugar tests was excess feed remaining from a previous DM1200 test [22]. Iodide (as KI), cadmium oxide, and selenium oxide had been spiked into this feed at a level corresponding to $0.1 \mathrm{wt} \%$ each in the glass if all was retained. These low level spikes were intended to trace the volatility of these elements and should have no significant effect on glass properties and sulfur volatility. This formulation at a lower concentration of $\mathrm{SO}_{3}$ of $0.24 \mathrm{wt} \%$ (as variations using $\pm 15 \%$ simulant from the nominal) was tested on the DM100 at VSL [7], the DM1200 at VSL [22], and the LAW Pilot Melter in Columbia, MD [16] with no processing problems. A list of the glass forming chemicals used to prepare the melter feeds is given in Table 2.4; these are the same chemical sources as are presently planned for use in the WTP.

The glass and feed compositions for the melter test with $\mathrm{V}_{2} \mathrm{O}_{5}$ were selected on the basis of glass formulation studies. A $\mathrm{V}_{2} \mathrm{O}_{5}$ concentration of $2.0 \mathrm{wt} \%$ was selected, as shown in Table 2.3, whereby the vanadium replaced the $2.0 \mathrm{wt} \% \mathrm{TiO}_{2}$ present in the LAWA44 composition. Crucible melts covering a range of vanadium concentrations in the LAWA44 base glass were tested for a variety of properties, including sulfur solubility and glass viscosity and electrical conductivity at various temperatures, as shown in Table 2.5. Little change was observed in these properties with changes in vanadium concentration. The viscosities of all three melts are within the desired $30-70$ Poise range at $1150^{\circ} \mathrm{C}$. Clear, homogeneous glasses resulted upon heat treatment at $850^{\circ} \mathrm{C}$ for twenty hours for all vanadium concentrations. The LAW 143 formulation was selected for subsequent melter tests. The glass forming chemicals used to prepare the melter feed were the same as those given for the urea and sugar Test in Table 2.4, except for the substitution of $\mathrm{V}_{2} \mathrm{O}_{5}$ for $\mathrm{TiO}_{2}$.

\subsection{Sugar Additions}

With high nitrate feeds, the addition of reductants is necessary in order to control melt foaming. Sugar, which was used for this purpose at West Valley, has also been selected as the baseline reductant for the WTP. The amount of sugar required increases with the amount of nitrates present in the feed and decreases with the amount of waste organics present in the feed, which themselves act as reductants. Excessive additions of reductants can be deleterious, leading to over-reduction of the melt and formation of sulfides and molten metals. Consequently, the oxidants and reductants in the feed must be suitably balanced. The basis for achieving this balance was developed by VSL and Duratek for the vitrification of high-sodium-nitrate feeds at Savannah River's M-Area and has been successfully applied to the processing of a wide variety of simulated WTP feeds over the past six years. In developing this approach, we elected to conservatively adopt the most reducing potential reaction as the basis for the definition of a "sugar" or stoichiometric ratio of 1.0 as a result of concerns for over-reducing the melt. Such a reaction, using sodium salts as an example, is:

$$
\mathrm{C}_{12} \mathrm{H}_{22} \mathrm{O}_{11}+8 \mathrm{NaNO}_{3}=8 \mathrm{CO}_{2}+4 \mathrm{CO}+4 \mathrm{~N}_{2}+11 \mathrm{H}_{2} \mathrm{O}+4 \mathrm{Na}_{2} \mathrm{O}
$$


The Catholic University of America Vitreous State Laboratory
Glass Formulation Testing to Increase Sulfate Volatilization

Final Report, VSL-04R4970-1, Rev. 0

Fundamentally, the basis that is selected is simply a convention, since the precise stoichiometry of the reactions involved is neither known nor constant under the conditions prevailing in the melter. However, with this convention, a sugar ratio of 1.0 corresponds to one mole of sucrose per eight moles of nitrate or, more generally, 1.5 moles of organic carbon per mole of nitrate. It is then expected that significantly less sugar than this will be required in practice. The empirically determined amount required to successfully control melt foaming without significantly reducing the glass melt was found to correspond to a ratio of 0.5 when any nitrites present were counted as nitrates (i.e., 0.75 moles of organic carbon per mole of nitrate + nitrite). This approach has been employed for all WTP melter testing. It is, however, expected that slight variations around the nominal value of 0.5 may be necessary to account for differences in the reducing power of waste organics in comparison to sugar, particularly for LAW streams that are high in organics.

As an example, the calculation of the amount of sugar needed for the present SubEnvelope A1 feed to achieve a sugar ratio of 0.5 proceeds as follows:

- One liter of simulant contains 1.888 moles of nitrite and 1.978 moles of nitrate, giving a total of 3.866 moles of NOx (see Table 2.1)

- Required total amount of organic carbon for a sugar ratio of 0.5 is 3.866 x $0.75=2.900$ moles

- One liter of simulant contains 0.462 moles of organic carbon (see Table 2.1)

- Therefore, $2.900-0.462=2.438$ moles of organic carbon must be added.

Since the molecular weight of sucrose is $342 \mathrm{~g}$ per mole, $2.438 \times 342 / 12=69.48 \mathrm{~g}$ sugar must be added per liter of simulant, as shown in Table 2.4. Note that for the version of the simulant given in Table 2.2, the total concentration of nitrate and nitrite is slightly higher (3.905 vs. 3.866 M) and the TOC is lower $(0.174$ vs. $0.462 \mathrm{M})$ and therefore the amount sugar required to achieve a stoichiometric ratio of 0.5 is greater (78.5 g vs. $69.48 \mathrm{~g}$ ), as shown in Table 2.4. Similar calculations were conducted with urea and starch using molecular weights of $60 \mathrm{~g}$ per mole with one carbon and 162 g per mole with five carbons, respectively. 
The Catholic University of America Vitreous State Laboratory
Glass Formulation Testing to Increase Sulfate Volatilization Final Report, VSL-04R4970-1, Rev. 0

\section{$2.4 \quad$ Analysis of Feed Samples}

\subsubsection{General Properties}

Feed samples were analyzed from DM100 tests using each simulant batch to confirm physical properties and chemical composition. Samples taken during testing were from an inline sampling port. Sample names, sampling dates, and measured properties are given in Table 2.6 along with corresponding average measured values from previous tests with a similar melter feed [22]. The narrow range in the measured water content, density, glass yield, and $\mathrm{pH}$ values show the consistency of the feed received from Optima and the lack of effect of the test reductants on these properties. The measured glass yields were about $8 \%$ below the target values due perhaps to high estimates in the purity of the additives as well as water added during the transfer of feed.

\subsubsection{Rheology}

Samples of the melter feeds that were used for these tests were also subjected to rheological characterization. The results from rheological characterization of a variety of other melter feeds and waste simulants, as well as the effects of a range of test variables, are described in detail in a separate report [29]. Melter feeds were characterized using a Haake RS75 rheometer, which was equipped with either a Z40DIN or a FL22-SZ40 sensor. A typical set of measurements consists of identifying the flow characteristics of the slurry by measuring the shear stress on the slurry at controlled shear rates and temperatures. In these measurements, the shear rate values are preset and are increased stepwise from $0.01 \mathrm{~s}^{-1}$ to $200 \mathrm{~s}^{-1}\left(70 \mathrm{~s}^{-1}\right.$ for FL22SZ40) with a sufficient delay (typically 15 to 30 seconds) between steps to ensure that shear stress is allowed to fully relax and therefore is measured at equilibrium. This approach is somewhat different from the "flow curve" approach in which the shear rate is ramped up to some maximum value and then ramped back down to produce a hysteresis curve that is dependent on the selected ramp rate. The viscosity of the sample as a function of the shear rate is then calculated as the ratio of the shear stress to the shear rate. The yield stress data for the melter feeds were measured using a controlled-stress mode in which the torque on the rotor was slowly increased while the resulting deformation of the fluid was monitored. The discontinuity in the measured deformation-torque curve was identified as the yield stress. It should be noted that this direct measurement of the yield stress can be quite different from the value that is often reported as the yield stress, which is obtained by extrapolation of the shear stress-shear rate curve to zero shear rate. All of the measurements in this work were made at $25^{\circ} \mathrm{C}$; previous work [29], which examined a range of temperatures, showed a relatively weak effect of temperature.

Rheograms for the melter feeds, which show the feed viscosity versus shear rate, are presented in Figure 2.1. Also included in that figure are values measured for feed from the previous DM1200 test using the same LAW A simulant [22]. Figure 2.2 shows an alternative presentation of the data as plots of the shear stress versus shear rate; also included are proposed WTP bounds for feed rheology [30]. Measured yield stress and viscosity at selected shear rates are given in Table 2.6. The rheological properties of the feed with the vanadium additive are very similar to the previously used DM1200 feed and are well within the proposed bounds. Conversely, feeds from the starch and sugar test are considerably more viscous to the extent of 
being outside the defined bounds. No difficulties were encountered processing this feed; however, tests with feeds with higher starch concentrations tended to gel and could not be processed (see Section 3.3).

\subsubsection{Chemical Composition}

The chemical compositions of the feed samples were determined by first making a glass from the feed sample via crucible melt. The glass was subsequently crushed and analyzed directly by X-Ray Fluorescence Spectroscopy (XRF). The boron oxide target value was used for normalizing the XRF data since its concentration was not determined by XRF. The results, which are compared to the target compositions in Table 2.7, generally corroborate the consistency of the feed composition and show good agreement with the target composition for the major components. Of the oxides with a target composition greater than one percent, only magnesium oxide had a deviation greater than $10 \%$ from target. This deviation was also observed in the product glasses but was considerably smaller in magnitude (see Section 5.1). Deficits of magnesium oxide measured in the feed samples being substantially less in the product glass have been observed in several previous studies [7, 8, 22, 31, 32] and are unexplained. Volatile minor elements such as sulfur, selenium, and chlorine are, as expected, below target due to loss during crucible melting. The target sulfur concentrations in the feed, which is important for determining sulfur retention in the glass, are verified from the simulant vendor's batching sheets. Additional amounts of sulfur added by the VSL are calculated, checked, and weighed out using calibrated balances. 


\section{SECTION 3.0 \\ DM10 SCOPING TESTS}

Melter tests were conducted on the DM10 with the LAW Sub-Envelope A1 simulant between 11/17/03 and 12/6/03 to screen four reductants for future use on the DM100-WV. These tests produced over 325 kilograms of glass from approximately 0.7 metric tons of feed. The tests, listed in the order in which they were performed, were as follows:

- Test A1: Four 14-hour feeding segments with sugar at stoichiometries of 0.5, 0.75, 1.0, and 1.25 .

- Test A4: Three 14-hour feeding segments with sugar at a stoichiometry of 0.5 and urea at stoichiometries of $0.25,0.5$, and 0.75 .

- Test A2: Four 14-hour feeding segments with starch at stoichiometries of 0.5, 0.75, 1.0, and 1.25.

- Test A3: Four 14-hour feeding segments with polyethylene glycol (PEG molecular weight: 600) at stoichiometries of $0.5,0.75,1.0$, and 1.25 .

The principal objective of these tests was to determine the types and concentrations of reductants that result in the maximum amount of sulfur volatilization without overly reducing the glass or creating other processing problems. Processing conditions, including the glass pool temperature of $1150^{\circ} \mathrm{C}$, mimicked those to be used on the DM100. Test segment durations of 14 hours were selected since, at the target glass production rate, this provided three melt pool turnovers $(24 \mathrm{~kg})$ for each reductant concentration.

\subsection{DM10 System Description}

\subsubsection{Feed System}

The feed container is mounted on a load cell for weight monitoring and is stirred continuously except for periodic, momentary interruptions during which the weight is recorded. The material in the feed container is constantly recirculated, which provides additional mixing. The recirculation loop extends to the top of the melter where feed is diverted from the recirculation loop through a peristaltic pump into the melter through a Teflon-lined feed line and vertical water-cooled feed tube. A diverter valve permits direction of the feed stream either to the melter or to a sampling vessel.

\subsubsection{Melter}

The DM10 system used for this work is a ceramic refractory lined melter, which includes two Inconel 690 plate electrodes that are used for joule-heating of the glass pool and a bubbler for agitating the melt. Glass is discharged from the melter using an air-lift system. The melt pool 
has a surface area of $0.021 \mathrm{~m}^{2}$ and typically contains about $8 \mathrm{~kg}$ of glass. The plenum volume is 19.5 liters at the nominal glass level.

\subsubsection{Off-Gas System}

For operational simplicity, the DM10 is equipped with a dry off-gas treatment system involving gas filtration operations only. Exhaust gases leave the melter plenum through a film cooler device that minimizes the formation of solid deposits. The film cooler air has constant flow rate and its temperature is thermostatically controlled. The geometry of the transition line (between the melter and the first filtration device) conforms to the requirements of the 40-CFR60 air sampling techniques. Immediately downstream of the transition line are cyclonic filters followed by conventional pre-filters and HEPA filters. The temperature of the cyclonic filters is maintained above $150^{\circ} \mathrm{C}$ while the HEPAs are held above $100^{\circ} \mathrm{C}$ to prevent moisture condensation. The entire train of gas filtration operations is duplicated and each train is used alternately. An induced draft fan completes the system. The sampling location for gaseous species monitored by FTIR is immediately downstream of the draft fan.

\subsection{DM10 Test Results}

Table 3.1 provides a summary of the DM10 tests including run times, types and amount of reductants used, the amount of feed sulfur and iodine retained in the glass product, the measured iron oxidation state, and the concentration of various gaseous constituents in the emissions. Since the DM10 tests served as scoping tests to identify the best candidates for DM100 testing, not all of the glass samples listed in Table 3.1 were analyzed for their redox state. Previous reports [3-9] provide data from tests with baseline concentrations of sugar (stoichiometric carbon ratio of 0.5 ) and at marginally higher concentrations up to a stoichiometric carbon ratio of 0.75. Previous tests with LAW Sub-Envelope A1 [7] feed at stoichiometric carbon ratios of 0.57 and 0.44 resulted in glass $\mathrm{Fe}^{2+}$ contents of $6 \%$ and $<0.8 \%$ of the total iron, respectively. Tests with a LAW Sub-Envelope C2 feed [9] at 0.75 stoichiometric carbon ratio resulted in $22 \%$ of the total iron as $\mathrm{Fe}^{2+}$ in the glass. A listing of all the glasses discharged and analysis performed is given in Table 3.2. The methods used were XRF for glass compositional analysis (see Section 2.4.3), colorimetric analysis for iron oxidation state (see Section 5.2), and FTIR for stack exhaust analysis (see Section 6.2). Sulfur and iodine compositional trends over the course of the tests are depicted in Figures 3.1 - 3.4.

Results for most of the reductants showed the expected trends: as the stoichiometric ratio increased, sulfur retention in the glass decreased and the amount of divalent iron in the glass increased. Tests with polyethylene glycol were an exception since very little change in sulfur concentration was observed as a result of changes in PEG concentration and the amount of reduced iron actually decreased as the concentration of PEG increased. However, the redox state at the beginning of the PEG test may have been biased high by the prior starch test. In addition, it was difficult to distinguish differences in glass sulfur concentrations between the two highest urea concentrations, although the glass is clearly more reduced as the urea concentration 
increases.

The effectiveness of the reductants in volatilizing sulfur from the glass was as follows:

$$
\text { Starch }>\text { Sugar }>\text { Urea }+ \text { Sugar }>>\text { PEG }
$$

The effectiveness of the reductants in reducing iron was slightly different:

$$
\text { Sugar }>\text { Starch }>\text { Urea }+ \text { Sugar }>>\text { PEG }
$$

The optimum reductant would volatilize the maximum amount of sulfur without significantly affecting the redox state of the glass melt. Starch is the more effective reductant tested with respect to volatilizing sulfur and producing a smaller shift in glass redox state than sugar, making it attractive for future tests. A stoichiometric ratio of 0.75 with starch resulted in less than ten percent reduced iron while volatilizing about a quarter of the sulfur; this was therefore selected for further testing on the DM100. The other reductants selected for DM100 testing were urea and sugar at a stoichiometric ratio of 1.0 with half the carbon provided by each compound. This combination resulted in less sulfur retention in the glass than starch at a stoichiometric ratio of 0.75 with less than twenty percent reduced iron in the glass product. Sugar alone was not selected for DM100 testing, even though it was effective at volatilizing sulfur, because of the observed tendency to significantly reduce iron at stoichiometric ratios of 0.75 or greater $[5,9]$.

Other points of interest in the results from the DM10 tests were the effects that the reductants had on iodine retention in the glass and gaseous emissions. At stoichiometric ratios greater than 0.75, 30-40 percent of the feed iodine was retained in the glass for all reductant types except PEG. This is in keeping with tests using LAW simulants conducted at stoichiometric levels of 0.75 or greater [9]; it is also consistent with results from tests with HLW simulants when sufficient sugar was added to create reducing conditions in the cold cap [34]. Although not depicted here, selenium concentrations were monitored during the DM10 tests and showed no obvious trend with reductant type or concentration. Gaseous emissions followed the expected trends for the sugar and urea plus sugar tests: decreasing NOx emissions and increasing byproduct (carbon monoxide, ammonia, and nitriles) emissions with increasing feed carbon content. Increasing the starch concentration appeared to have no effect on NOx emissions and little effect on byproduct generation. Conversely, increasing PEG concentration resulted in systematic reductions of NOx but concentrations of byproducts, and particularly ammonia, were high at all PEG concentrations.

\subsection{Final Evaluation of Reductants Selected from DM10 Tests}

No processing problems were encountered with any of the reductants during DM10 testing; however, additional tests were performed to ensure that no problems would occur under the different conditions present in the DM100 feed system. Temperatures in the DM100 feed tank range between 30 and $40^{\circ} \mathrm{C}$ due to the close proximity to the melter whereas feed in the 
DM10 feed tank is close to room temperature. Feed stability for each of the proposed reductants was therefore evaluated at temperatures up to $45^{\circ} \mathrm{C}$ in beakers placed in a constant temperature bath. No problems were encountered with urea and sugar feed at any of the concentrations tested; however, starch at concentrations higher than a stoichiometric ratio of 0.5 formed a thick gel above $35^{\circ} \mathrm{C}$ resulting in a feed with unacceptable rheological properties. Therefore, the stoichiometric ratio of 0.75 for the DM100 test was achieved using starch at a stoichiometric ratio of 0.5 in combination with sugar at a stoichiometric ratio of 0.25 . 
The Catholic University of America Vitreous State Laboratory
Glass Formulation Testing to Increase Sulfate Volatilization Final Report, VSL-04R4970-1, Rev. 0

\section{SECTION 4.0 DM100 OPERATIONS}

Melter tests were conducted on the DM100-WV with the LAW Sub-Envelope A1 simulant between $12 / 10 / 03$ and $1 / 30 / 04$. These tests produced almost $1350 \mathrm{~kg}$ of glass from approximately 2.7 metric tons of feed. The tests were 50 to 60 hours in duration and were divided as follows:

- Urea and Sugar Test: Stoichiometric ratio of 1; 0.5 urea and 0.5 sugar

- Vanadium Additive Test: 2.0 wt $\% \mathrm{TiO}_{2}$ in the target glass replaced with $\mathrm{V}_{2} \mathrm{O}_{5}$; stoichiometric ratio of 0.5 with sugar (i.e., current WTP nominal level)

- Starch and Sugar Test: Stoichiometric ratio of 0.75; 0.5 starch and 0.25 sugar

Table 4.1 provides summaries for the three tests. Attempts were made to replicate the melter configuration and operating conditions used for the corresponding tests conducted earlier $[7,27]$ and the previous LAW Sub-Envelope [5-9, 33, 35, 36] tests. These conditions include a near-complete cold cap, which is between $80-95 \%$ melt surface coverage for the DM100, since a $100 \%$ cold cap tends to lead to "bridging" in smaller melters. The target production rate of $2000 \mathrm{~kg} / \mathrm{m}^{2} /$ day was approximated for most of the testing (see Figures 4.1.a,b,c), although about a day of processing was required in the Urea and Sugar Test to achieve this rate, as depicted in Figure 4.1.a. As typically observed, production rates vary from the target at the onset of feeding while the cold cap becomes established; in addition, instantaneous rates varied by as much as $25 \%$ as a result of variable feed pulse sizes. No processing problems were observed, and no secondary sulfate phase was observed before or after any of the tests. No interruptions were experienced due to feed system clogging.

The results of various operational measurements that were made during these tests are given in Table 4.2. Glass temperatures are shown in Figures 4.2.a - 4.2.c, plenum temperatures in Figures 4.3.a - 4.3.c, and electrode temperatures in Figures 4.4.a - 4.4.c. Power supplied to the electrodes is shown in all the figures. Bulk glass temperatures approximated the target glass temperature of $1150^{\circ} \mathrm{C}$. Glass temperatures near the top of the melt pool are not reliable indicators of bulk glass temperatures as a result of gradients near the cold cap. Plenum temperatures typically ranged within the 450 to $650^{\circ} \mathrm{C}$ target but were mostly in the upper part of the range. This is deliberately somewhat higher than for the larger melters (DM1200 and LAW Pilot Melter) in order to reduce cold cap bridging that occurs in the smaller melters. The West electrode temperature averaged between $1125-1148^{\circ} \mathrm{C}$, the East electrode $10-35^{\circ} \mathrm{C}$ less, and the bottom electrode was typically about $200-250^{\circ} \mathrm{C}$ cooler than the side electrodes. The bottom electrode was not powered during these tests. Power supplied to the electrodes typically varied by only $2 \mathrm{~kW}$ from the average value. The average bubbling rates were higher (22 vs. $16 \mathrm{lpm}$ ) for the first two tests than the last test or other previous tests due to natural aging and corrosion of the bubbler, which was apparent upon removal of the bubbler after the Vanadium Additive Test, after which the bubbler was replaced. 
The Catholic University of America Vitreous State Laboratory
Glass Formulation Testing to Increase Sulfate Volatilization Final Report, VSL-04R4970-1, Rev. 0

The gas temperature at the film cooler averaged between 290 and $294^{\circ} \mathrm{C}$, depending on the plenum temperature as well as the amount and temperature of added film cooler air. Little or no drop in gas temperature was observed across the (insulated) transition line, which serves to prevent condensation, as intended. 
The Catholic University of America Vitreous State Laboratory
Glass Formulation Testing to Increase Sulfate Volatilization Final Report, VSL-04R4970-1, Rev. 0

\section{SECTION 5.0 DM100 GLASS PRODUCTS}

Almost $1350 \mathrm{~kg}$ of glass was produced in these tests. The glass was discharged from the melter periodically into 5-gallon carbon steel pails using an airlift system. The discharged product glass was sampled at the end of each test by removing sufficient glass from the top of the cans for total inorganic analysis. Product glass masses, discharge date, and analysis performed are listed in Table 5.1. Glass samples were also obtained by dipping a rod into the glass pool at the beginning and end of each test. These "dip samples" underwent visual examinations to detect the presence of a separate sulfate phase on the glass surface as well as total inorganic compositional analysis.

\subsection{Compositional Analysis}

Glass discharge and dip samples were crushed and analyzed directly by XRF. The target value for boron oxide, which is not determined by XRF, was used for normalizing the XRF data to $100 \mathrm{wt} \%$. The XRF-analyzed compositions of discharged glass samples are provided in Table 5.2 and, for selected samples, are compared with the results of DCP analysis of solutions generated by microwave aided acid dissolution in Table 5.3. Results for dip samples by XRF are provided in Table 5.4. All discharged glass and dip samples were subjected to XRF analysis. The majority of the XRF analysis results compared very favorably to their corresponding target values. The only significant oxide with a relative deviation from target greater than $10 \%$ was $\mathrm{MgO}$, which was about $11 \%$ below the target value in the Urea and Sugar test. Measured boron concentrations were within three percent of the target validating the use of the target value for normalizing the XRF data. Agreement between the two analytical methods was excellent except for low sodium values obtained from the DCP analysis, which is likely due to a low-bias for sodium; previous experience indicates that the XRF results are more reliable in this regard. Compositional trends for most of the major constituents during the tests shown in Figures 5.1 and 5.2 illustrate the closeness to target and the consistency of composition over the course of the tests. The intended decrease of titanium and increase in vanadium during the second test is readily observed. Note that the glass pool was turned over with frit generated during the DM10 and Urea and Sugar Tests prior to commencing the last test and therefore the concentrations of titanium and vanadium change abruptly between the Vanadium Additive Test and the Starch and Sugar Test. No deviations in the concentrations of other major constituents were apparent as a result of the turnover with frit or the idling period between the tests.

Cadmium, iodine, and selenium were spiked into the feed that was used in the Starch and Sugar Test at concentrations of $0.1 \mathrm{wt} \%$ each in the glass product, assuming total retention. The concentrations of these elements over the course of the tests are depicted in Figure 5.3. Predictably, their concentrations were at or below detectable levels until frit containing these elements was introduced into the melter at the end of the Vanadium Additive Test. Steady-state concentrations were obtained by the end of the Starch and Sugar Test of about 0.024, 0.044, and $0.092 \mathrm{wt} \%$ for selenium, iodine, and cadmium, respectively. Previous studies have shown that 
iodine retention in glass is very low except when processing feed with high alkali content [22, 27, 36] and higher than nominal concentrations of reductants [9, 34]. Feed processed in the DM10 (see Section 3.0) and the Starch and Sugar Test satisfied both of these criteria, resulting in nearly half the iodine being retained in the feed. Selenium and cadmium retentions were 10 to $30 \%$ below those observed while processing the same feed in the DM1200 due perhaps to the thicker and more extensive cold cap coverage possible on the larger melter.

The concentrations of chlorine and sulfur, which are also relatively volatile, are plotted over the course of the tests in Figure 5.4. Notice that during each test, steady-state concentrations of $\mathrm{SO}_{3}$ and chlorine are attained. The concentration of sulfur decreases with increasing feed carbon content; the Vanadium Additive Test had the lowest stoichiometric carbon ratio and had the highest glass sulfur concentrations, whereas the Urea and Sugar test had the highest stoichiometric carbon ratio and had the lowest glass sulfur concentrations. The disparity between the concentration of sulfur in the glass during these tests is greater than observed in previous tests with same formulation [7, 27] due to the higher reductant content, change in additives, and the concentration of sulfur in the feed (0.5 vs. $\left.0.19-0.26 \mathrm{wt} \% \mathrm{SO}_{3}\right)$. Sulfur in the glass samples was measured mostly by XRF and occasionally by ion chromatography (IC). XRF results show better precision than the IC results and, based on our previous experience, we place greater confidence in the XRF results. $\mathrm{SO}_{3}$ measurement by IC requires a glass digestion step during which loss of sulfur by volatilization is a possibility. This is probably the reason for the occasional low sulfur result measured by IC as compared to the XRF result for the same sample. The chlorine concentration was largely unaffected by the changes in additive type and carbon concentration. It is also considerably more volatile than sulfur, as seen by concentrations showing wider deviations from the target and the decreases in concentration during the idling periods between tests.

Glass dip samples were obtained at the beginning and end of each test, primarily to ascertain whether a secondary sulfate layer had formed on the surface of the glass melt. Table 5.4 provides a listing of all of the dip samples together with their analyzed compositions and whether or not a separate salt phase was evident. All dip samples taken were free of secondary phases. Also note that the measured dip sample compositions are close to the target compositions for most of the major elements and that sulfur and chlorine concentrations in dip samples taken at the end of a test are close to the corresponding concentrations in the discharge samples.

\subsection{Iron Redox State}

The iron oxidation states for glass samples from all tests were measured using colorimetric methods. The method detection limit of $0.5 \%$ divalent iron reported here is dependent on several factors including the level (6.9 wt\%) of $\mathrm{Fe}_{2} \mathrm{O}_{3}$ in the target glass. Sample information including name, test, and the amount of glass produced for all samples analyzed for divalent iron are given in Table 5.5. The glass samples from the end of tests with greater than 0.5 stoichiometric carbon had reduced iron concentrations between 20-25\%, whereas glass samples from the Vanadium Additive Test were almost completely oxidized. The latter result is in keeping with previous tests with LAW feeds at stoichiometric ratios of 0.5 [5, 6, 8, 9, 32] as well 
as the DM10 Starch (Test A2A) and Urea and Sugar (Test A4A) Tests. One of the glass samples from the Vanadium Additive Test was analyzed by both the colorimetric method and Mössbauer spectroscopy and showed $3 \%$ and $<5 \%$ divalent iron, respectively. The amount of reduced iron observed in the Urea and Sugar Test as well as the Starch and Sugar DM100 Test is higher than in the corresponding DM10 tests due in part to more complete cold cap coverage in the larger melter creating more reducing conditions in the underlying glass. The lower concentration of waste organics, which resulted in a higher proportion of the total carbon originating from sugar, also contributed to yielding a more reducing glass in the Urea and Sugar test. Previous tests with LAW simulants and sugar at stoichiometric ratios of 0.75 and 1.0 resulted in divalent iron concentrations of $22-30 \%$ and $26-45 \%$, respectively [4, 9]. Tests conducted in the present work with comparable amounts of total carbon but with significant amounts in the form of urea or starch resulted in lower concentrations of divalent iron since these compounds are not as effective at reducing iron in the glass melt as sugar. 


\section{SECTION 6.0 \\ MONITORED OFF-GAS EMISSIONS}

\subsection{Particulate Sampling}

The melter exhaust was sampled for metals/particles according to 40-CFR-60 Methods 3, 5 , and 29 at steady-state operating conditions during each DM100 test. The concentrations of off-gas species that are present as particulates and gaseous species that are collected in impinger solutions were derived from laboratory data on solutions extracted from air samples (filters and various solutions) together with measurements of the volume of air sampled. Particulate collection required isokinetic sampling, which entails removing gas from the exhaust at the same velocity that the air is flowing in the duct (40-CFR-60, Methods 1-5). Typically, a sample size of 30 dscf was taken at a rate of between 0.5 and $0.75 \mathrm{dscfm}$. Total particulate loading was determined by combining gravimetric analysis of the standard particle filter and chemical analysis of probe rinse solutions. An additional impinger containing $2 \mathrm{~N} \mathrm{NaOH}$ was added to the sampling train to ensure complete scrubbing of acid gases, particularly halogens. The collected materials were analyzed using direct current plasma atomic emission spectroscopy (DCP-AES) for the majority of the constituents and ion chromatography (IC) for anions. Melter emission fluxes are compared to feed fluxes in Table 6.1 where the distinction is made between constituents sampled as particles and as "gas". The "gaseous" constituents are operationally defined as those species that are scrubbed in the impinger solutions after the air stream has passed through a $0.3 \mu \mathrm{m}$ heated filter. All samples were within $10 \%$ of isokinetic.

Particulate emissions from the melter were high, at $0.6-2 \%$ of feed solids. Particulate melter emissions increase with increasing feed alkali content [3-9, 27, 33, 35-37] and therefore it is not surprising that the LAW Sub-Envelope A formulations, which have the highest sodium and halide content, also have the highest percent of particulate carry-over. The high solids carry-over of nonvolatile elements such as silica in the Starch and Sugar Test suggests that the increase is due to gross entrainment of feed into the exhaust stream, not volatilization. As expected, the feed elements emitted at the lowest melter DF were clearly halogens and sulfur. Iodine was detected in significant quantities as both gaseous and particulate emissions in the Sugar and Starch Test. This is in contrast to previous tests with LAW simulants and sugar at a stoichiometric ratio of 0.5 where iodine was almost exclusively detected in the basic impinger of the sampling train suggesting emissions were mostly in the form of molecular iodine. Chlorine and fluorine emissions were detected exclusively as particulate emissions in all three tests. Fluorine was detected in emissions from the first two tests even though it was not included in the target composition due to its ubiquity as a contaminant in water and raw materials. Sulfur emissions were mostly particulate except in the Starch and Sugar Test. Other elements exhibiting volatile behavior include alkali metals and chromium as well as selenium and cadmium in the Starch and Sugar Test. Boron, sulfur, and the halides were the only elements detected in the impinger solutions collected downstream of the heated particle filter in the sampling train, which constitutes the "gas" fraction of the melter emissions. 


\subsection{Gases Monitored by FTIR}

Melter emissions were monitored in each test for a variety of gaseous components, most notably CO and nitrogen species, by Fourier Transform Infra Red Spectroscopy (FTIR). The off-gas system temperature is maintained well above $100^{\circ} \mathrm{C}$ beyond the sampling port downstream of the HEPA filter to prevent analyte loss due to condensation prior to monitoring. A summary of the average and the range of concentrations monitored during each test is provided in Tables 6.2 and 6.3, respectively. The concentrations of various monitored species are plotted in Figures 6.1 - 6.3. The large variations in the measured concentrations evident in these figures are a result of the pulsed feeding system and the dynamic nature of the cold cap. The analytes listed in the tables are those that were expected to be observed during the test, based on previous work; no other species were detected in the off-gas stream by FTIR. Hydrogen concentrations were also monitored in the tests by gas chromatography and are included in Table 6.2. The most abundant nitrogen species monitored was NO, which is consistent with previous tests [3-9, 27, 33, 35-37] in which nitrates and nitrites were abundant in the feed. The concentrations of $\mathrm{NO}_{2}$ and $\mathrm{N}_{2} \mathrm{O}$ were an order of magnitude lower than $\mathrm{NO}$ in the Vanadium Additive Test and decreased with respect to NO by a factor of four as the stoichiometric ratio was increased from 0.5 to 1.0. Measured concentrations of nitrogen oxides decreased with increasing feed carbon content while byproducts of organic matter decomposition such as $\mathrm{NH}_{3}$ and $\mathrm{CO}_{2}$ increased, which is also consistent with previous tests. Ammonia concentrations were particularly high in the test with urea, which is expected based on the known production of ammonia on the thermal decomposition of urea. Carbon monoxide and acetonitrile concentrations were the highest in the Starch and Sugar Test, even though more carbon was present in the feed than was used in the Urea and Sugar Test. Hydrogen emissions were highest in the Vanadium Additive Test, suggesting that hydrogen emissions are not solely dependent on feed carbon content; it is not clear what role, if any, vanadium may play in the observed increase in hydrogen concentrations. No gaseous $\mathrm{HF}$ or $\mathrm{HCl}$ were detected by FTIR, consistent with the results from the Method 5-type sampling discussed in Section 6.1.

The results of a nitrogen mass balance are summarized in Table 6.4. In keeping with previous tests, the percent of feed nitrates and nitrites emitted as nitrogen oxides was inversely related to the amount of carbon in the feed $[5,9]$. Also, consistent with previous tests with feed at a sugar ratio of 0.5 [3-9, 27, 33, 35-37], about $50 \%$ of the feed nitrogen oxides were reduced to diatomic nitrogen in the Vanadium Additive Test. For the reductants tested in the present work, the quantity rather than the type of carbon appeared to be the dominant factor in determining nitrogen oxide emissions. This observation is in contrast to results from tests using other reductants, such as formic acid [8] and various waste organics (EDTA, glycolic acid, oxalic acid, acetic acid, and citric acid), which indicated that these compounds were considerably less effective at reducing nitrogen oxide emissions than sugar. 


\subsection{Mass Balance for Volatile Constituents}

Table 6.5 provides the percentages of sulfur, chlorine, iodine, and selenium that were retained in the glass product or identified in the various off-gas stream samples for each of the tests. Data for other DM100 tests processing LAW Sub-Envelope A1 simulants are included for comparison. The chlorine mass balance around the melter was excellent for all tests, with totals ranging from 93 - 102 percent. Closure for sulfur was not as good but within $20 \%$ for all three tests. Sulfur retention in the glass ranged between 66 and $78 \%$, depending on the concentration of carbon in the feed. Less sulfur was retained in the glass during the current three tests than for any of the previous tests, including those conducted at temperatures as high as $1225^{\circ} \mathrm{C}$ [31]. At the nominal operating temperatures, a 20 to 30 percent decrease in the sulfur concentrations in the glass can be attributed to the use of vandadium or the reductants used in these tests that are different from the WTP baseline. Emissions of sulfur were mostly in the form of particles for all LAW Sub-Envelope A1 tests except the Starch and Sugar Test, which was the test with the largest excess of sulfur over $100 \%$. The sulfur particulate emissions were similar to those observed in previous tests conducted on the DM100 [27, 33, 36]. About half the chlorine was retained in the glass, with the other half emitted from the melter as particles in the LAW SubEnvelope A1 tests. The excess chlorine recovery in the high temperature tests suggests the feed used in that test may have had chlorine at above the target concentration. Iodine retention in the glass during the Starch and Sugar Test was higher (40\% vs. 20\%) than for the comparable test at the nominal stoichiometric carbon ratio. Aside from elements that are not appreciably incorporated in the glass structure such as nitrogen, selenium was the most volatile element studied with less than a quarter of the amount fed being retained in the glass. 


\section{SECTION 7.0 SUMMARY AND CONCLUSIONS}

Several tests were conducted on the DM10 and DM100 vitrification systems to assess the effectiveness of various reductants in increasing the extent of volatilization of sulfur from glass melts. A previously tested glass formulation for the LAW Sub-Envelope A1 simulant with sulfur content increased to $0.5 \mathrm{wt} \% \mathrm{SO}_{3}$ was used. Four different organic reductants - sugar, urea, starch, and polyethylene glycol, each at several concentrations - were evaluated on the DM10 for their effects on sulfur volatilization and iron redox state in the glass product. Based on these results as well as melter feed rheology testing, combinations of urea and starch with sugar were selected for further testing on the DM100. In addition, the tests also evaluated an inorganic additive for its effects on sulfur volatilization: vanadium was used as an additive in place of titanium in tests performed on the DM100 at the WTP nominal level of organic reductant (sugar at a stoichiometric ratio of 0.5 with respect to nitrates and nitrites). No difficulties were encountered during processing and at no time during or after testing did a separate sulfate phase form on the melt pool surface. Tests were successful at volatilizing between 22 and $34 \%$ of the feed sulfur from the glass while maintaining only modest shifts of the redox state of the melt pool. More sulfur was volatilized from the glass than in previous tests conducted at melt temperatures as high as $1225^{\circ} \mathrm{C}$.

During the present tests, total particulate emissions from the melter ranged from 0.6 $2 \mathrm{wt} \%$. Melter DFs were determined for each element in the feed for the three DM100 tests that were performed. Increases in reductant concentrations resulted in increased particulate sulfur emissions but had little effect on other volatile elements such as chlorine. Good mass balance closure around the melter was achieved for sulfur and chlorine. Iodine retention in the glass increased by a factor of two as the stoichiometric carbon ratio increased from 0.5 to 0.75 .

For streams for which sulfur is the waste-loading-limiting component, which is the case for many of the Hanford LAW waste streams, partitioning some of the sulfur to somewhere other than the glass will result in a proportionate increase in waste loading, which, in turn, will result in a proportionate reduction in the volume of glass that is produced. These results are therefore potentially significant to the DOE because the volume of glass drives the processing and disposal costs. Therefore, if $20-30 \%$ of the sulfur can be volatilized, $20-30 \%$ less glass might be produced, assuming that the volatilized sulfur is not recycled into the melter feed. This work clearly shows that there are significant differences between reductants in their effect on glass redox and the amount of feed sulfur that is partitioned to the off-gas. This fact is important because it implies that further optimization should be possible simply because there are differences in the behavior of reductants with respect to their effect on glass redox and sulfur retention in the glass. 


\section{SECTION 8.0 RECOMMENDATIONS FOR FUTURE WORK}

While it is clear that the addition of reductants to the melter feed will increase the extent of sulfur partitioning to the off-gas stream, it is also clear that highly reducing conditions in combination with sulfur in the melt can lead to the formation of metal sulfides and, ultimately metallic phases in the melter, which can have serious deleterious operational consequences. Consequently, the basic issue addressed in the present work is the extent to which reductants, mixtures of reductants, or inorganic additives can be tailored to maximize the partitioning of sulfur to the off-gas stream while minimizing the reducing effect on the glass melt. The results of this work demonstrate that alternative reductants, reductant mixtures, and vanadium as an inorganic additive can indeed be effective in this regard. However, these results obtained on a relatively small number of potential additives also indicate that there is considerable scope for further improvement if this approach were to be pursued for application in the WTP. The present study focused on the magnitude of the effects and the extent of the differences between additives (reductants and inorganics additives) on sulfur partitioning and reduction of the melt under melter test conditions that are relevant to the WTP. However, the present study was not directed at understanding the basic mechanisms involved, and the reasons for the differences in the behavior of the different additives; such a study would be of value in the selection and further optimization of additives to enhance sulfate volatilization for the melter. Future work should address:

- Testing of other reductants over a range of concentrations;

- Testing of other combinations of reductants over a range of concentrations;

- Testing of reductants in combination with vanadium;

- Testing of other potential inorganic additives;

- Testing of reductants, combinations of reductants, and/or inorganic additives at higher temperatures;

- Longer duration tests to evaluate the potential formation of reduced phases;

- Larger scale tests to address scale-up effects;

- Basic tests to address the reactions and processes that are involved in maximizing sulfur partitioning while minimizing melt redox shifts in order to more efficiently down-select potential additives.

The present study clearly demonstrates that this approach for partitioning sulfur to the off-gas is of value in increasing waste loading in LAW glasses, thereby reducing LAW glass volume, and processing and disposal costs. By performing the additional work outlined above, the results of the present study would be confirmed by longer duration testing and at larger melter scales, which would ultimately underpin this promising method of enhancing the waste processing rate at the WTP LAW facility. Results from tests to understand the basic mechanisms involved will help guide selection and further optimization of additives to enhance sulfate volatilization while minimizing undesirable reduction of the glass melt. However, the advantages of this approach are predicated on the present sulfur recycle loop at the WTP being broken. 


\section{SECTION 9.0 REFERENCES}

[1] LAW Pilot Melter Decommissioning and Testing, Letter Subcontract \#DE-AC2703RV14539.

[2] “Glass Formulation and Testing with RPP-WTP LAW Simulants," Final Report, I.S. Muller, A.C. Buechele, and I.L. Pegg, VSL-00R3560-2, Rev. 0, Vitreous State Laboratory, The Catholic University of America, Washington, DC, 2/23/01.

[3] "Melter Tests with LAW Envelope B Simulants to Support Enhanced Sulfate Incorporation,” Final Report, K.S. Matlack, S. P. Morgan, and I.L. Pegg, VSL-00R35011, Rev. 0, Vitreous State Laboratory, The Catholic University of America, Washington, DC, $11 / 27 / 00$.

[4] "Melter Tests with LAW Envelope A and C Simulants to Support Enhanced Sulfate Incorporation,” K.S. Matlack, S. Morgan, and I.L. Pegg, VSL-01R3501-2, Vitreous State Laboratory, The Catholic University of America, Washington, DC, 1/26/01.

[5] "Compositional Variation Tests on DuraMelter 100 with LAW Sub-Envelope A3 Feed in Support of the LAW Pilot Melter,” K.S. Matlack, W. Gong, and I.L. Pegg, VSL01R62N0-1, Rev. 0, Vitreous State Laboratory, The Catholic University of America, Washington, DC, 1/8/02.

[6] "Compositional Variation Tests on DuraMelter 100 with LAW Sub-Envelope C1 Feed (LAWC22 Glass) in Support of the LAW Pilot Melter,” K.S. Matlack, W. Gong, and I.L. Pegg, VSL-02R62N0-2, Rev. 0, Vitreous State Laboratory, The Catholic University of America, Washington, DC, 2/11/02.

[7] "Compositional Variation Tests on DuraMelter 100 with LAW Sub-Envelope A1 Feed (LAWA44 Glass) in Support of the LAW Pilot Melter,” K.S. Matlack, W. Gong, and I.L. Pegg, VSL-02R62N0-4, Rev. 0, Vitreous State Laboratory, The Catholic University of America, Washington, DC, 6/18/02.

[8] "Compositional Variation Tests on DuraMelter 100 with LAW Sub-Envelope A2 Feed (LAWA88 Glass) in Support of the LAW Pilot Melter,” K.S. Matlack, W. Gong, and I.L. Pegg, VSL-02R62N0-3, Rev. 0, Vitreous State Laboratory, The Catholic University of America, Washington, DC, 6/26/02.

[9] “Compositional Variation Tests on DuraMelter 100 with LAW Sub-Envelope C2 Feed in Support of the LAW Pilot Melter,” K.S. Matlack, W. Gong, R.A. Callow and I.L. Pegg, VSL-04R4410-1, Rev. 0, Vitreous State Laboratory, The Catholic University of America, Washington, DC, 6/17/04. 
[10] “RPP-WTP Pilot Melter Envelope A and C Throughput Test Results Report,” Duratek, Inc., TRR-PLT-54, 10/13/00.

[11] “RPP-WTP Pilot Melter Envelope B Throughput Test Results Report,” Duratek, Inc., TRR-PLT-57, 10/13/00.

[12] "RPP-WTP Pilot Melter Off-Gas System Sampling (High Sulfate Envelope C) Test Results Report,” Duratek, Inc., TRR-PLT-56B, 10/11/00.

[13] “RPP-WTP Pilot Melter Sub-Envelope A3 Variation Test Results Report,” Duratek, Inc., TRR-PLT-060, 2/11/02.

[14] “RPP-WTP Pilot Melter Sub-Envelope C1 Variation Test Results Report,” Duratek, Inc., TRR-PLT-060, 6/28/02.

[15] “RPP-WTP Pilot Melter Sub-Envelope Variation A2 Test Results Report,” Duratek, Inc., TRR-PLT-070, 6/4/02.

[16] “RPP-WTP Pilot Melter Sub-Envelope Variation A1 Test Results Report,” Duratek, Inc., TRR-PLT-071, 7/25/02.

[17] “Glass Formulation Testing to Increase Sulfate Volatilization from Melter," K.S. Matlack, I.S. Muller, I.L. Pegg, S. Bennett, and I. Joseph, Test Plan to Dept. of Energy, Office of River Protection, VSL-03T4970-1, Rev. 0, Vitreous State Laboratory, The Catholic University of America, Washington, DC, 11/3/03.

[18] "Summary of Preliminary Results on Enhanced Sulfate Incorporation During Vitrification of LAW Feeds”, I.L. Pegg, H. Gan, I.S. Muller, D.A. McKeown, and K.S. Matlack, VSL-00R3630-1, April 52000.

[19] "Glasses for Immobilisation of Sulfate-Containing Radioactive Wastes", S.V. Stefanovskii and F.A. Lifanov, Radiokhimiya, 31 [6] (1989) 746-751.

[20] “Quality Assurance Project Plan for RPP-WTP Support Activities Conducted by VSL,” Vitreous State Laboratory, QAPP Rev. 6, Vitreous State Laboratory, The Catholic University of America, Washington, DC, 11/12/03.

[21] "Master List of Controlled VSL Manuals and Standard Operating Procedures in Use," QA-MLCP, Rev. 10, Vitreous State Laboratory, The Catholic University of America, Washington, DC, 2/16/04.

[22] "Integrated Off-Gas System Tests on the DM1200 Melter with RPP-WTP LAW SubEnvelope A1 Simulants,” K.S. Matlack, W. Gong, T. Bardakci, N. D’Angelo, and I.L. Pegg, VSL-02R8800-2, Rev. 0, Vitreous State Laboratory, The Catholic University of America, Washington, DC, 9/03/02. 
[23] “Tank Farm Contractor Operation and Utilization Plan,” R.A. Kirkbride, et al., CH2M Hill Hanford Group Inc., Richland, WA, HNF-SD-SP-012, Rev. 3, 10/2/01.

[24] “Tank Farm Contractor Operation and Utilization Plan,” R.A. Kirkbride, et al., CH2M Hill Hanford Group Inc., Richland, WA, HNF-SD-SP-012, Rev. 2, 4/19/00.

[25] “Tank Waste Remediation System (TWRS) Privatization Contractor Samples - Waste Envelope B Material, 241-AN-105," R.A. Esch, HNF-SD-WM-DP-218, Rev. 1, 5/30/1997.

[26] "LAW Pilot Melter and DM-100 Sub-Envelope Changeover Testing,” Rev. 0, 24590LAW-TSP-RT-02-012.

[27] “DuraMelter 100 Sub-Envelope Changeover Testing Using LAW Sub-Envelopes A1 and C1 Feeds in Support of the LAW Pilot Melter,” K.S. Matlack, W. Gong, and I.L. Pegg, VSL-02R62N0-6, Rev. 0, Vitreous State Laboratory, The Catholic University of America, Washington, DC, 6/13/03.

[28] “Basis of Design,” BNFL report, DB-W375-EG00001, Rev. 0, November 23, 1998.

[29] "Physical and Rheological Properties of Waste Simulants and Melter Feeds for RPPWTP LAW Vitrification,” Final Report, I.S. Muller, H. Gan, and I.L. Pegg, VSL00R3520-1, Rev. 0, Vitreous State Laboratory, The Catholic University of America, Washington, DC, 1/16/01.

[30] "Development of LAW and HLW Vitrification Physical Property Bounding Conditions and Simulant Verification Criteria,” A. Poloski, H. Smith, G. Smith, and B. Calloway, WTP-RPT-075, Rev 0, 2/03.

[31] "Small Scale Melter Testing to Assess Impact of Higher Temperature Melter Operations,” K.S. Matlack, W. Gong, and I.L. Pegg, Final Report to Dept. of Energy, Office of River Protection, VSL-04R4980-1, Rev. 0, Vitreous State Laboratory, The Catholic University of America, Washington, DC, 2/13/04.

[32] "Integrated Off-Gas System Tests on the DM1200 Melter with RPP-WTP LAW SubEnvelope C1 Simulants,” K.S. Matlack, W. Gong, T. Bardakci, D’Angelo, and I.L. Pegg, VSL-02R8800-1, Rev. 0, 7/25/02.

[33] "DuraMelter 100 Sub-Envelope Changeover Testing Using LAW Sub-Envelope A3 and C2 Feeds in Support of the LAW Pilot Melter,” K.S. Matlack, W. Gong, and I.L. Pegg, VSL-03R3410-3, Rev 0, Vitreous State Laboratory, The Catholic University of America, Washington, DC, 10/17/03. 
[34] "Integrated DM1200 Melter Tests of Redox Effects Using HLW AZ-101 and C-106/AY102 Simulants,” K.S. Matlack, W. Gong, T. Bardakci, N. D’Angelo, W. Lutze, P. M. Bizot, R. A. Callow, M. Brandys, W. K. Kot and I.L. Pegg, VSL-04R4800-1, Rev. 0, $5 / 6 / 04$.

[35] "Compositional Variation Tests on DuraMelter 100 with LAW Sub-Envelope B2 Feed in Support of the LAW Pilot Melter," K.S. Matlack, W. Gong, and I.L. Pegg, VSL03R3410-2, Rev. 0, Vitreous State Laboratory, The Catholic University of America, Washington, DC, 10/7/03.

[36] "DuraMelter 100 Sub-Envelope Changeover Testing Using LAW Sub-Envelope A2 and B1 Feeds in Support of the LAW Pilot Melter," K.S. Matlack, W. Gong, and I.L. Pegg, VSL-03R3410-1, Rev 0, Vitreous State Laboratory, The Catholic University of America, Washington, DC, 8/22/03.

[37] "Comparison of Off-Gas Emissions from Tests with LAW Simulants on the DM100, DM1200, and DM3300 Melters,” R.A. Callow, K.S. Matlack, and I.L. Pegg, Summary Report, VSL-04S4850-1, Rev. 0, 4/19/04. 
Table 2.1. LAW Sub-Envelope A1 Simulant Recipe at 8 Molar Sodium Used in DM10 Tests.

\begin{tabular}{|c|c|c|c|c|c|c|c|c|c|c|c|}
\hline \begin{tabular}{c|} 
Envelope \\
Constituents
\end{tabular} & \multicolumn{2}{|c|}{$\begin{array}{l}\text { Simulant AN-105 (sup) } \\
\text { including Pretreatment }\end{array}$} & $\begin{array}{l}\text { Glass } \\
\text { Oxides }\end{array}$ & $\mid \begin{array}{c}\text { LAW A1 } \\
\text { Simulant as } \\
\text { Oxides (wt\%) }\end{array}$ & $\begin{array}{c}\text { Waste } \\
\text { Contribution } \\
\text { to Glass }\end{array}$ & $\begin{array}{l}\text { Source in } \\
\text { Simulant }\end{array}$ & $\begin{array}{l}\text { Order for } \\
\text { Addition }\end{array}$ & $\begin{array}{l}\text { Formula } \\
\text { Weight }\end{array}$ & Assay & Ratio & $\begin{array}{c}\text { Target } \\
\text { Weight (g) }\end{array}$ \\
\hline- & $\mathrm{mg} / \mathrm{l}$ & $\mathrm{M}$ & Loading & \begin{tabular}{|l|l|}
- & \\
\end{tabular} & $25.849 \%$ & \multicolumn{6}{|c|}{ In $285 \mathrm{ml}$ water add following compounds in the order listed below } \\
\hline \multirow[t]{2}{*}{ Al } & \multirow[t]{2}{*}{28595} & \multirow[t]{2}{*}{1.060} & \multirow[t]{2}{*}{$\mathrm{Al}_{2} \mathrm{O}_{3}$} & \multirow[t]{2}{*}{16.862} & \multirow{2}{*}{4.359} & $\mathrm{Al}\left(\mathrm{NO}_{3}\right)_{3} \cdot 9 \mathrm{H}_{2} \mathrm{O}, 60 \%$ sol. & 1 & 375.14 & 0.59 & 0.14 & 387.68 \\
\hline & & & & & & $\mathrm{Al}(\mathrm{OH})_{3}$ & 7 & 78.00 & 0.77 & 0.65 & 46.11 \\
\hline $\mathrm{Ca}$ & 58 & 0.001 & $\mathrm{CaO}$ & 0.025 & 0.007 & $\mathrm{Ca}\left(\mathrm{NO}_{3}\right)_{2} * 4 \mathrm{H}_{2} \mathrm{O}$ & 2 & 236.16 & 0.99 & 0.24 & 0.34 \\
\hline $\mathrm{Cr}$ & 166 & 0.003 & $\mathrm{Cr}_{2} \mathrm{O}_{3}$ & 0.076 & 0.020 & $\mathrm{Na}_{2} \mathrm{CrO}_{4} * 4 \mathrm{H}_{2} \mathrm{O}$ & 10 & 234.04 & 0.99 & 0.19 & 0.76 \\
\hline Cs (spike) & 1686 & 0.013 & $\mathrm{Cs}_{2} \mathrm{O}$ & 0.558 & 0.144 & $\mathrm{CsNO}_{3}$ & 3 & 194.91 & 1.00 & 0.72 & 2.48 \\
\hline $\mathrm{Fe}$ & 19 & 0.000 & $\mathrm{Fe}_{2} \mathrm{O}_{3}$ & 0.009 & 0.002 & $\mathrm{Fe}\left(\mathrm{NO}_{3}\right)_{3} * 9 \mathrm{H}_{2} \mathrm{O}$ & 4 & 404.01 & 1.00 & 0.20 & 0.14 \\
\hline $\mathrm{K}$ & 4570 & 0.117 & $\mathrm{~K}_{2} \mathrm{O}$ & 1.718 & 0.444 & $\mathrm{KOH}$ & 9 & 56.10 & 0.85 & 0.84 & 7.71 \\
\hline $\mathrm{Na}$ & 183920 & 8.000 & $\mathrm{Na}_{2} \mathrm{O}$ & 77.371 & 20.000 & $\mathrm{NaOH}, 50 \%$ sol. $\mathrm{d}=1.53$ & 8 & 40.00 & 0.48 & 0.77 & 440.63 \\
\hline $\mathrm{Ni}$ & 28 & 0.000 & $\mathrm{NiO}$ & 0.011 & 0.003 & $\mathrm{Ni}\left(\mathrm{NO}_{3}\right)_{3} * 6 \mathrm{H}_{2} \mathrm{O}$ & 5 & 290.81 & 1.00 & 1.00 & 0.14 \\
\hline $\mathrm{Si}$ & 150 & 0.005 & $\mathrm{SiO}_{2}$ & 0.100 & 0.026 & $\mathrm{SiO}_{2}$ & 11 & 60.09 & 0.99 & 1.00 & 0.33 \\
\hline $\mathrm{Cl}$ & 6933 & 0.196 & $\mathrm{Cl}$ & 2.164 & 0.559 & $\mathrm{NaCl}$ & 12 & 58.45 & 0.99 & 0.61 & 11.55 \\
\hline $\mathrm{F}$ & 305 & 0.016 & $\mathrm{~F}$ & 0.095 & 0.025 & $\mathrm{NaF}$ & 13 & 42.00 & 0.99 & 0.45 & 0.68 \\
\hline $\mathrm{PO}_{4}$ & 1121 & 0.012 & $\mathrm{P}_{2} \mathrm{O}_{5}$ & 0.261 & 0.068 & $\mathrm{Na}_{3} \mathrm{PO}_{4} * 12 \mathrm{H}_{2} \mathrm{O}$ & 14 & 380.12 & 0.99 & 0.19 & 4.53 \\
\hline $\mathrm{SO}_{4}$ & 2883 & 0.030 & $\mathrm{SO}_{3}$ & 0.750 & 0.194 & $\mathrm{Na}_{2} \mathrm{SO}_{4}$ & 15 & 142.06 & 0.99 & 0.56 & 4.31 \\
\hline $\mathrm{NO}_{2}$ & 86856 & 1.888 & $\mathrm{NO}_{2}$ & - & - & $\mathrm{NaNO}_{2}$ & 22 & 69.00 & 0.97 & 0.55 & 134.31 \\
\hline $\mathrm{NO}_{3}$ & 122642 & 1.978 & $\mathrm{NO}_{3}$ & - & - & $\mathrm{NaNO}_{3}$ & - & 84.99 & 0.99 & 0.73 & \\
\hline $\mathrm{CO}_{3}$ & 11938 & 0.199 & $\mathrm{CO}_{3}$ & - & - & $\mathrm{Na}_{2} \mathrm{CO}_{3}$ & 23 & 105.99 & 1.00 & 0.58 & 21.09 \\
\hline $\mathrm{NH}_{3}$ & 2335 & 0.137 & $\mathrm{NH}_{3}$ & - & - & $\mathrm{NH}_{4} \mathrm{NO}_{3}$ & 21 & 80.04 & 1.00 & 0.21 & 10.98 \\
\hline $\mathrm{OH}$ & 93721 & 5.513 & $\mathrm{OH}$ & - & - & $\begin{array}{l}\text { From } \mathrm{KOH}+\mathrm{NaOH}+ \\
\mathrm{Al}(\mathrm{OH})_{3}\end{array}$ & - & - & - & - & - \\
\hline Org.Carbon & 5543 & 0.462 & - & - & - & - & - & - & - & - & - \\
\hline EDTA & 3640 & 0.013 & - & - & - & $\mathrm{Na}_{2}$ EDTA $^{*} 2 \mathrm{H}_{2} \mathrm{O}(\mathrm{C} 10)$ & 6 & 372.24 & 0.99 & 0.32 & 4.72 \\
\hline HEDTA & 4321 & 0.016 & - & - & - & $\begin{array}{l}\mathrm{Na}_{3} \mathrm{HEDTA}^{*} 2 \mathrm{H}_{2} \mathrm{O} \quad 41 \% \text { sol. } \\
(\mathrm{C} 10)\end{array}$ & 16 & 380.24 & 0.448 & 0.32 & 13.34 \\
\hline Acetate & 2115 & 0.036 & - & - & - & Sodium Acetate* $3 \mathrm{H}_{2} \mathrm{O} \quad(\mathrm{C} 2)$ & 17 & 136.08 & 0.99 & 0.18 & 4.92 \\
\hline Formate & 2007 & 0.045 & - & - & - & Sodium Formate (C1) & 18 & 68.01 & 0.99 & 0.18 & 3.06 \\
\hline Oxalate & 677 & 0.008 & - & - & - & Sodium Oxalate (C2) & 19 & 134.00 & 0.99 & 0.18 & 1.04 \\
\hline Glycolate & 1820 & 0.024 & - & - & - & Glycolic Acid (C2) & 20 & 76.05 & 0.67 & 0.32 & 2.72 \\
\hline- & - & - & - & - & - & & Target Gl & & & & 1239.60 \\
\hline- & - & - & SUM & 100.00 & 25.849 & & tal simulant & jeight & & & 1388.55 \\
\hline
\end{tabular}

NOTE: Potassium iodide was spiked into the feed at VSL at a level corresponding to $0.1 \mathrm{wt} \%$ iodine in the glass if it were all retained. Cadmium and selenium were spiked at $1124 \mathrm{mg} / \mathrm{l}$ and $899 \mathrm{mg} / \mathrm{l}$, respectively, in the simulant, which corresponds to $0.1 \mathrm{wt} \%$ of each oxide in the glass.

"-" Empty data field 
Table 2.2. LAW Envelope A (AN-105) Waste Simulant Recipe at 8 Molar Sodium.

\begin{tabular}{|c|c|c|c|c|c|c|c|c|c|c|c|}
\hline $\begin{array}{c}\text { Envelope } \\
\text { Constituents }\end{array}$ & $\begin{array}{l}\text { Simulan } \\
\text { including }\end{array}$ & $\begin{array}{l}\mathrm{N}-105 \\
\text { eatment }\end{array}$ & $\begin{array}{l}\text { Glass } \\
\text { Oxides }\end{array}$ & $\begin{array}{l}\text { AN-105 } \\
\text { Wt } \%\end{array}$ & $\begin{array}{c}\mathrm{AN}-105 \\
\mathrm{Wt} \% \text { in glass }\end{array}$ & $\begin{array}{l}\text { Source in } \\
\text { Simulant }\end{array}$ & $\begin{array}{l}\text { Order for } \\
\text { Addition }\end{array}$ & $\begin{array}{l}\text { Formula } \\
\text { Weight }\end{array}$ & Assay & \multirow[t]{2}{*}{ Ratio } & \multirow[t]{2}{*}{$\begin{array}{c}\text { Target } \\
\text { Weight (g) }\end{array}$} \\
\hline$-\quad$ & $\mathrm{mg} / \mathrm{L}$ & $\mathrm{M}$ & Loading & - & $26.039 \%$ & \multicolumn{4}{|c|}{ In $274.40 \mathrm{ml}$ water add following compounds in the order listed below } & & \\
\hline $\mathrm{Al}$ & 30554 & 1.132 & $\mathrm{Al}_{2} \mathrm{O}_{3}$ & 17.886 & 4.657 & $\begin{array}{l}\mathrm{Al}\left(\mathrm{NO}_{3}\right) 3.9 \mathrm{H}_{2} \mathrm{O}, 60 \% \text { sol. } \\
\mathrm{Al}(\mathrm{OH})_{3}\end{array}$ & $\begin{array}{l}1 \\
8 \\
\end{array}$ & $\begin{array}{c}375.14 \\
78.00 \\
\end{array}$ & $\begin{array}{l}0.61 \\
1.00 \\
\end{array}$ & $\begin{array}{l}0.14 \\
0.66 \\
\end{array}$ & $\begin{array}{r}419.32 \\
35.56 \\
\end{array}$ \\
\hline $\mathrm{B}$ & 79 & 0.007 & $\mathrm{~B}_{2} \mathrm{O}_{3}$ & 0.078 & 0.020 & $\mathrm{H}_{3} \mathrm{BO}_{3}$ & 3 & 61.83 & 0.99 & 0.56 & 0.45 \\
\hline $\mathrm{Cr}$ & 149 & 0.003 & $\mathrm{Cr}_{2} \mathrm{O}_{3}$ & 0.067 & 0.018 & $\mathrm{Na}_{2} \mathrm{CrO}_{4} * 4 \mathrm{H}_{2} \mathrm{O}$ & 7 & 234.04 & 0.99 & 0.19 & 0.68 \\
\hline Cs (spike) & 1739 & 0.013 & $\mathrm{Cs}_{2} \mathrm{O}$ & 0.571 & 0.149 & $\mathrm{CsNO}_{3}$ & 2 & 194.91 & 1.00 & 0.72 & 2.56 \\
\hline $\mathrm{K}$ & 4608 & 0.118 & $\mathrm{~K}_{2} \mathrm{O}$ & 1.720 & 0.448 & $\mathrm{KOH}$ & 6 & 56.10 & 0.91 & 0.84 & 7.28 \\
\hline $\mathrm{Na}$ & 183920 & 8.000 & $\mathrm{Na}_{2} \mathrm{O}$ & 76.807 & 20.000 & $\mathrm{NaOH}, 50 \%$ sol. $\mathrm{d}=1.53$ & 5 & 40.00 & 0.50 & 0.77 & 463.20 \\
\hline Si & 157 & 0.006 & $\mathrm{SiO}_{2}$ & 0.104 & 0.027 & $\mathrm{SiO}_{2}$ & 4 & 60.09 & 0.99 & 1.00 & 0.34 \\
\hline $\mathrm{Cl}$ & 6996 & 0.197 & $\mathrm{Cl}$ & 2.167 & 0.564 & $\mathrm{NaCl}$ & 9 & 58.45 & 0.99 & 0.61 & 11.65 \\
\hline $\mathrm{F}$ & 35 & 0.002 & $\mathrm{~F}$ & 0.011 & 0.003 & $\mathrm{NaF}$ & 10 & 42.00 & 0.99 & 0.45 & 0.08 \\
\hline $\mathrm{SO}_{4}$ & 2274 & 0.024 & $\mathrm{SO}_{3}$ & 0.587 & 0.153 & $\mathrm{Na}_{2} \mathrm{SO}_{4}$ & 11 & 142.06 & 0.99 & 0.56 & 3.40 \\
\hline $\mathrm{NO}_{2}$ & 85428 & 1.857 & - & - & - & $\mathrm{NaNO}_{2}$ & 15 & 69.00 & 0.97 & 0.55 & 128.79 \\
\hline $\mathrm{NO}_{3}$ & 126988 & 2.048 & - & - & - & $\mathrm{NaNO}_{3}$ & - & 84.99 & 0.99 & 0.73 & 0.00 \\
\hline TOC & 2093 & 0.174 & - & - & - & - & - & - & - & - & - \\
\hline Acetate & 2251 & 0.038 & - & - & - & Sodium Acetate. $3 \mathrm{H}_{2} \mathrm{O}(\mathrm{C} 2)$ & 12 & 136.08 & 0.99 & 0.18 & 5.24 \\
\hline Formate & 2135 & 0.047 & - & - & - & Sodium Formate (C1) & 13 & 68.01 & 0.99 & 0.18 & 3.26 \\
\hline Glycolate & 1936 & 0.025 & - & - & - & Glycolic Acid (C2) & 14 & 76.05 & 0.71 & 0.32 & 2.73 \\
\hline- & - & - & - & - & - & & Target & & & & 1239.60 \\
\hline- & - & - & SUM & 100 & 26.039 & & Total simu & it wt. & & & 1358.94 \\
\hline
\end{tabular}

"-" Empty data field 
The Catholic University of America Vitreous State Laboratory
Glass Formulation Testing to Increase Sulfate Volatilization Final Report, VSL-04R4970-1, Rev. 0

Table 2.3. Oxide Composition of LAW Sub-Envelope A1 Simulant and Corresponding Glass Compositions (wt\%).

\begin{tabular}{|c|c|c|c|c|}
\hline Glass Oxides & $\begin{array}{c}\text { LAWA44 } \\
\text { Glass }\end{array}$ & $\begin{array}{l}\text { DM10 Glass, } \\
\text { DM100 } \\
\text { (Starch + } \\
\text { Sugar Test) }\end{array}$ & $\begin{array}{c}\text { DM100 } \\
\text { (Urea + } \\
\text { Sugar Test) }\end{array}$ & $\begin{array}{l}\text { DM100 } \\
\text { (Vanadium } \\
\text { Test) }\end{array}$ \\
\hline $\mathrm{Al}_{2} \mathrm{O}_{3}$ & 6.18 & 6.13 & 6.15 & 6.15 \\
\hline $\mathrm{B}_{2} \mathrm{O}_{3}$ & 8.98 & 8.91 & 8.91 & 8.91 \\
\hline $\mathrm{CaO}$ & 1.99 & 1.97 & 1.99 & 1.99 \\
\hline $\mathrm{CdO}$ & - & 0.10 & - & - \\
\hline $\mathrm{Cr}_{2} \mathrm{O}_{3}$ & 0.02 & 0.02 & 0.02 & 0.02 \\
\hline $\mathrm{Cs}_{2} \mathrm{O}$ & 0.14 & 0.14 & 0.15 & 0.15 \\
\hline $\mathrm{Fe}_{2} \mathrm{O}_{3}$ & 6.96 & 6.91 & 6.93 & 6.93 \\
\hline $\mathrm{K}_{2} \mathrm{O}$ & 0.44 & 0.44 & 0.45 & 0.45 \\
\hline $\mathrm{MgO}$ & 1.99 & 1.97 & 1.99 & 1.99 \\
\hline $\mathrm{Na}_{2} \mathrm{O}$ & 20.02 & 20.07 & 20.24 & 20.24 \\
\hline $\mathrm{NiO}$ & $<0.01$ & $<0.01$ & - & - \\
\hline $\mathrm{SeO}_{2}$ & - & 0.10 & - & - \\
\hline $\mathrm{SiO}_{2}$ & 44.44 & 44.13 & 44.22 & 44.22 \\
\hline $\mathrm{TiO}_{2}$ & 1.99 & 1.97 & 1.99 & - \\
\hline $\mathrm{V}_{2} \mathrm{O}_{5}$ & - & - & - & 1.99 \\
\hline $\mathrm{ZnO}$ & 2.96 & 2.94 & 2.95 & 2.95 \\
\hline$\overline{\mathrm{ZrO}_{2}}$ & 2.98 & 2.96 & 2.97 & 2.97 \\
\hline $\mathrm{Cl}$ & 0.56 & 0.56 & 0.56 & 0.56 \\
\hline $\mathrm{F}$ & 0.02 & 0.02 & $<0.01$ & $<0.01$ \\
\hline $\mathrm{I}$ & - & 0.10 & - & - \\
\hline $\mathrm{P}_{2} \mathrm{O}_{5}$ & 0.07 & 0.07 & $<0.01$ & $<0.01$ \\
\hline $\mathrm{SO}_{3}$ & 0.24 & 0.50 & 0.50 & 0.50 \\
\hline Total & 100.00 & 100.00 & 100.00 & 100.00 \\
\hline
\end{tabular}




\section{Table 2.4. Glass Forming Additives for 1 Liter of Simulant (8 M Na) and Corresponding Melter Feed Properties.}

\begin{tabular}{|c|c|c|}
\hline Additives Source & $\begin{array}{l}\text { DM10 Glass, } \\
\text { DM100 (Starch + } \\
\text { Sugar Test) }\end{array}$ & $\begin{array}{c}\text { DM100 (Urea + } \\
\text { Sugar Test) }\end{array}$ \\
\hline Additives in Glass (wt\%) & 74.15 & 73.96 \\
\hline Kyanite $\left(\mathrm{Al}_{2} \mathrm{SiO}_{5}\right) 325$ Mesh (Kyanite Mining) (g) & 42.46 & 35.84 \\
\hline $\mathrm{H}_{3} \mathrm{BO}_{3}$ (US Borax - Technical Granular) (g) & 200.66 & 200.17 \\
\hline Wollanstonite NYAD 325 Mesh (NYCO Minerals) (g) & 52.14 & 52.48 \\
\hline $\mathrm{Fe}_{2} \mathrm{O}_{3}(97 \%$ Alfa) (g) & 81.65 & 81.90 \\
\hline Olivine $\left(\mathrm{Mg}_{2} \mathrm{SiO}_{4}\right) 325 \mathrm{Mesh}(\# 180$ Unimin) (g) & 51.92 & 52.09 \\
\hline $\mathrm{SiO}_{2}$ (Sil-co-Sil 75 US Silica)) (g) & 466.91 & 470.39 \\
\hline $\mathrm{TiO}_{2}$ (Rutile Airfloated Chemaloy)* (g) & 25.86 & 25.95 \\
\hline ZnO (KADOX - 920 Zinc Corp. of America) (g) & 36.80 & 36.88 \\
\hline Zircon $\mathrm{ZrSiO}_{4}$ (Flour) Mesh 325 (AM. Mineral) (g) & 55.61 & 55.63 \\
\hline Addition of Sucrose as Reductant (Stoichiometric Ratio - 0.5) (g) & 69.48 & 78.5 \\
\hline$+\mathrm{Na}_{2} \mathrm{SO}_{4}$ (based on formulation studies) (g) & 4.34 & 4.34 \\
\hline Simulant Weight for 1 liter $(\mathrm{g})$ & 1389 & 1359 \\
\hline Sum of Additives (g) & 1014 & 1011 \\
\hline Sum of Complete Batch (g) & 2403 & 2370 \\
\hline Final Volume (l) (based on measured density) & 1.40 & 1.35 \\
\hline Target Density $(\mathrm{g} / \mathrm{ml})$ & 1.67 & 1.75 \\
\hline Target Glass Yield (g/l of simulant) & 1243 & 1243 \\
\hline Target Weight \% Water in Slurry Feed & 37.6 & 35.3 \\
\hline Weight \% Additives in Slurry & 42.2 & 42.7 \\
\hline Target Glass Yield (g/kg of Feed) & 517 & 523 \\
\hline Target Glass Yield (g/l of Feed) & 860 & 915 \\
\hline Target Total Solids ( $\mathrm{g} / \mathrm{l}$ of Feed) & 1070 & 1132 \\
\hline Target Additives (g/l of Feed) & 703 & 747 \\
\hline
\end{tabular}

* $-\mathrm{V}_{2} \mathrm{O}_{5}$ is substituted for rutile in the Vanadium Additive Test. 
The Catholic University of America Vitreous State Laboratory
Glass Formulation Testing to Increase Sulfate Volatilization

Final Report, VSL-04R4970-1, Rev. 0

Table 2.5. Measured Properties of Crucible Glasses.

\begin{tabular}{|c|c|c|c|c|}
\hline \multicolumn{2}{|c|}{ Glass ID } & LAWA144 & LAWA143 & LAWA145 \\
\hline \multicolumn{2}{|c|}{$\begin{array}{c}\text { Target } \mathrm{V}_{2} \mathrm{O}_{5} \text { Concentration } \\
(\mathrm{Wt} \%)\end{array}$} & 1.0 & 2.0 & 4.0 \\
\hline \multicolumn{2}{|c|}{ Measured $\mathrm{SO}_{3}$ Solubility (Wt\%) } & 0.53 & 0.64 & 0.61 \\
\hline \multirow{9}{*}{ Viscosity (poise) } & $900^{\circ} \mathrm{C}$ & 1446 & 1648 & 1275 \\
\hline & $950^{\circ} \mathrm{C}$ & 624 & 714 & 570 \\
\hline & $1000^{\circ} \mathrm{C}$ & 301 & 346 & 284 \\
\hline & $1050^{\circ} \mathrm{C}$ & 159 & 184 & 154 \\
\hline & $1100^{\circ} \mathrm{C}$ & 91 & 105 & 90 \\
\hline & $1130^{\circ} \mathrm{C}$ & 67 & 77 & 67 \\
\hline & $1150^{\circ} \mathrm{C}$ & 55 & 64 & 56 \\
\hline & $1200^{\circ} \mathrm{C}$ & 35 & 41 & 36 \\
\hline & $1250^{\circ} \mathrm{C}$ & 23 & 27 & 25 \\
\hline \multirow{8}{*}{$\begin{array}{l}\text { Electrical } \\
\text { Conductivity } \\
(\mathrm{S} / \mathrm{cm})\end{array}$} & $900^{\circ} \mathrm{C}$ & 0.158 & 0.160 & 0.189 \\
\hline & $950^{\circ} \mathrm{C}$ & 0.203 & 0.212 & 0.234 \\
\hline & $1000^{\circ} \mathrm{C}$ & 0.256 & 0.270 & 0.284 \\
\hline & $1050^{\circ} \mathrm{C}$ & 0.316 & 0.332 & 0.339 \\
\hline & $1100^{\circ} \mathrm{C}$ & 0.385 & 0.396 & 0.397 \\
\hline & $1150^{\circ} \mathrm{C}$ & 0.463 & 0.463 & 0.458 \\
\hline & $1200^{\circ} \mathrm{C}$ & 0.549 & 0.532 & 0.522 \\
\hline & $1250^{\circ} \mathrm{C}$ & 0.644 & 0.601 & 0.589 \\
\hline
\end{tabular}


The Catholic University of America Vitreous State Laboratory
Glass Formulation Testing to Increase Sulfate Volatilization

Final Report, VSL-04R4970-1, Rev. 0

Table 2.6. Properties of Feed Samples from DM100 Melter Tests.

\begin{tabular}{|c|c|c|c|c|c|c|c|c|c|c|c|c|}
\hline \multirow{2}{*}{ Melter } & \multirow{2}{*}{ Test } & \multirow{2}{*}{ Date } & \multirow{2}{*}{ Name } & \multirow{2}{*}{$\begin{array}{c}\% \\
\text { Water }\end{array}$} & \multirow{2}{*}{\begin{tabular}{|l|} 
Density \\
$(\mathrm{g} / \mathrm{ml})$
\end{tabular}} & \multicolumn{2}{|c|}{ Glass Yield } & \multirow{2}{*}{ pH } & \multirow{2}{*}{$\begin{array}{c}\text { Yield } \\
\text { Stress } \\
\text { (Pa) }\end{array}$} & \multicolumn{3}{|c|}{ Viscosity (Poise) } \\
\hline & & & & & & $(\mathrm{kg} / \mathrm{kg})$ & $(g / l)$ & & & @1/s & $@ 10 / \mathrm{s}$ & $@ 100 / s$ \\
\hline \multirow{2}{*}{ DM100 } & $\begin{array}{l}\text { Vanadium } \\
\text { Additive }\end{array}$ & $5 / 13 / 04$ & WVX-F-16A & 39.91 & 1.69 & 0.486 & 821 & 12.17 & 0.7 & 2.58 & 0.50 & 0.27 \\
\hline & $\begin{array}{c}\text { Starch and } \\
\text { Sugar }\end{array}$ & $1 / 30 / 04$ & WVV-F-93A & 37.48 & 1.72 & 0.479 & 824 & 12.13 & 4.4 & 28.7 & 4.58 & 2.34 \\
\hline DM1200 & \multicolumn{3}{|c|}{ Average [22] } & 37.60 & 1.72 & 0.481 & 827 & 12.19 & 0.8 & 4.17 & 0.74 & 0.38 \\
\hline
\end{tabular}


The Catholic University of America Vitreous State Laboratory
Glass Formulation Testing to Increase Sulfate Volatilization

Final Report, VSL-04R4970-1, Rev. 0

Table 2.7. XRF Analyzed Composition for Melter Feed Samples (wt\%).

\begin{tabular}{|c|c|c|c|c|c|c|}
\hline- & \multicolumn{3}{|c|}{ Vanadium Additive Test } & \multicolumn{3}{|c|}{ Starch and Sugar Test } \\
\hline Constituent & Target & WVX-F-16A & \%Dev & Target & WVV-F-93A & \%Dev \\
\hline $\mathrm{Al}_{2} \mathrm{O}_{3}$ & 6.15 & 6.24 & 1.41 & 6.13 & 6.23 & 1.62 \\
\hline $\mathrm{B}_{2} \mathrm{O}_{3} *$ & 8.91 & 8.91 & NC & 8.91 & 8.91 & NC \\
\hline $\mathrm{CaO}$ & 1.99 & 2.16 & 8.74 & 1.97 & 1.88 & -4.72 \\
\hline $\mathrm{CdO}$ & $\S$ & $<0.01$ & NC & 0.10 & 0.14 & $\mathrm{NC}$ \\
\hline $\mathrm{Cl}$ & 0.56 & 0.11 & NC & 0.56 & 0.03 & NC \\
\hline $\mathrm{Cr}_{2} \mathrm{O}_{3}$ & 0.02 & 0.04 & NC & 0.02 & 0.04 & NC \\
\hline $\mathrm{Cs}_{2} \mathrm{O}$ & 0.15 & 0.10 & $\mathrm{NC}$ & 0.14 & 0.07 & NC \\
\hline $\mathrm{CuO}$ & $\S$ & $<0.01$ & NC & 0.02 & 0.07 & NC \\
\hline $\mathrm{Fe}_{2} \mathrm{O}_{3}$ & 6.93 & 6.37 & -8.06 & 6.91 & 6.64 & -3.85 \\
\hline $\mathrm{I}$ & $\S$ & $<0.01$ & NC & 0.10 & 0.01 & NC \\
\hline $\mathrm{K}_{2} \mathrm{O}$ & 0.45 & 0.46 & 1.90 & 0.44 & 0.48 & 8.06 \\
\hline $\mathrm{MgO}$ & 1.99 & 1.59 & -19.97 & 1.97 & 1.68 & -14.67 \\
\hline $\mathrm{Na}_{2} \mathrm{O}$ & 20.24 & 19.73 & -2.53 & 20.07 & 20.69 & 3.10 \\
\hline $\mathrm{NiO}$ & $\S$ & 0.01 & $\mathrm{NC}$ & $<0.01$ & $<0.01$ & NC \\
\hline $\mathrm{P}_{2} \mathrm{O}_{5}$ & $\S$ & 0.02 & $\mathrm{NC}$ & 0.07 & 0.10 & $\mathrm{NC}$ \\
\hline $\mathrm{SeO}_{2}$ & $\S$ & $<0.01$ & NC & 0.10 & $<0.01$ & NC \\
\hline $\mathrm{SiO}_{2}$ & 44.22 & 45.88 & 3.76 & 44.13 & 45.16 & 2.33 \\
\hline $\mathrm{SO}_{3}$ & 0.50 & 0.27 & $\mathrm{NC}$ & 0.50 & 0.19 & $\mathrm{NC}$ \\
\hline $\mathrm{TiO}_{2}$ & $\S$ & 0.13 & NC & 1.97 & 1.99 & 1.14 \\
\hline $\mathrm{V}_{2} \mathrm{O}_{5}$ & 1.99 & 2.00 & 0.53 & $\S$ & 0.01 & NC \\
\hline $\mathrm{ZnO}$ & 2.95 & 2.93 & -0.76 & 2.94 & 2.74 & -6.79 \\
\hline $\mathrm{ZrO}_{2}$ & 2.97 & 3.04 & 2.44 & 2.96 & 2.94 & -0.56 \\
\hline Sum & 100.00 & 100.00 & NC & 100.00 & 100.00 & $\mathrm{NC}$ \\
\hline
\end{tabular}

* Target value

$\S$ - Not a target constituent

NC - Not calculated

"-" Empty data field 
Table 3.1. Summary of DM10 Test Conditions and Results.

\begin{tabular}{|c|c|c|c|c|c|c|c|c|}
\hline \multicolumn{2}{|c|}{ Test \# } & A1A & A1B & A1C & A1D & A4A & A4B & $\mathrm{A} 4 \mathrm{C}$ \\
\hline \multirow{3}{*}{ Time } & Feed Start & $\begin{array}{c}11 / 17 / 03 \\
14: 59\end{array}$ & $\begin{array}{c}11 / 18 / 03 \\
5: 19\end{array}$ & $\begin{array}{c}11 / 18 / 03 \\
20: 07\end{array}$ & $\begin{array}{c}11 / 19 / 03 \\
10: 35\end{array}$ & $\begin{array}{c}11 / 20 / 03 \\
1: 50\end{array}$ & $\begin{array}{c}11 / 20 / 03 \\
17: 15\end{array}$ & $\begin{array}{c}11 / 21 / 03 \\
7: 46\end{array}$ \\
\hline & Feed End & $\begin{array}{c}11 / 18 / 03 \\
4: 59\end{array}$ & $\begin{array}{c}11 / 18 / 03 \\
19: 45\end{array}$ & $\begin{array}{c}11 / 19 / 03 \\
10: 19\end{array}$ & $\begin{array}{c}11 / 20 / 03 \\
1: 30\end{array}$ & $\begin{array}{c}11 / 20 / 03 \\
17: 00\end{array}$ & $\begin{array}{c}11 / 21 / 03 \\
7: 15\end{array}$ & $\begin{array}{c}11 / 21 / 03 \\
21: 46\end{array}$ \\
\hline & $\begin{array}{c}\text { Net Slurry } \\
\text { Feeding (hr) }\end{array}$ & 14.0 & 14.4 & 14.2 & 14.9 & 15.2 & 14.0 & 14.0 \\
\hline \multirow{3}{*}{ Carbon } & Type & Sugar & Sugar & Sugar & Sugar & $\begin{array}{l}\text { Urea / } \\
\text { Sugar* }\end{array}$ & $\begin{array}{l}\text { Urea / } \\
\text { Sugar* }\end{array}$ & $\begin{array}{l}\text { Urea / } \\
\text { Sugar* }\end{array}$ \\
\hline & Sugar ratio & 0.5 & 0.75 & 1.0 & 1.25 & 0.75 & 1.0 & 1.25 \\
\hline & $\begin{array}{c}\text { Mol. } \mathrm{NO}_{\mathrm{x}} \text { : } \\
\text { Mol. Total } \\
\text { Organic } \\
\text { Carbon }\end{array}$ & 1: 0.75 & 1: 1.13 & 1: 1.5 & 1: 1.88 & 1: 1.13 & $1: 1.5$ & 1: 1.88 \\
\hline \multirow{5}{*}{ Product } & $\begin{array}{l}\text { Measured } \\
\text { wt\% } \mathrm{SO}_{3}\end{array}$ & 0.45 & 0.38 & 0.32 & 0.29 & 0.39 & 0.34 & 0.33 \\
\hline & $\begin{array}{c}\text { \% Feed } \\
\text { Sulfur in } \\
\text { Glass Product }\end{array}$ & 90 & 76 & 64 & 58 & 78 & 68 & 66 \\
\hline & $\% \mathrm{Fe}^{+2}$ & NA & NA & 45 & 55 & 3 & 19 & 29 \\
\hline & $\begin{array}{l}\text { Measured } \\
\text { wt\% I }\end{array}$ & 0.02 & 0.04 & 0.04 & 0.04 & 0.04 & 0.04 & 0.03 \\
\hline & $\begin{array}{l}\text { \% Feed I in } \\
\text { Glass Product }\end{array}$ & 20 & 45 & 40 & 45 & 45 & 40 & 30 \\
\hline \multirow{6}{*}{$\begin{array}{c}\text { Stack } \\
\text { Emissions } \\
\text { (ppmv) }\end{array}$} & NO & 330 & 180 & 120 & 100 & 250 & 65 & 67 \\
\hline & $\mathrm{NO}_{2}$ & 23 & 4.1 & 1.1 & $<0.1$ & 7.8 & 1.2 & $<0.1$ \\
\hline & $\mathrm{SO}_{2}$ & $<0.1$ & 1.8 & 2.7 & 3.3 & 1.7 & 2.0 & 2.7 \\
\hline & $\mathrm{CO}$ & 14 & 24 & 110 & 200 & 20 & 25 & 82 \\
\hline & $\mathrm{NH}_{3}$ & 28 & 73 & 100 & 130 & 76 & 49 & 92 \\
\hline & Acetonitrile & $<0.1$ & 7.5 & 20 & 25 & 3.1 & 3.2 & 12 \\
\hline
\end{tabular}

* - Sugar was at a stoichiometric ratio of 0.5 for all tests with urea.

NA - Not Analyzed. 
Table 3.1. Summary of DM10 Test Conditions and Results (continued).

\begin{tabular}{|c|c|c|c|c|c|c|c|c|c|}
\hline & Test \# & $\mathrm{A} 2 \mathrm{~A}$ & A2B & A2C & A2D & A3A & АЗВ & АЗС & A3D \\
\hline \multirow{3}{*}{ Time } & Feed Start & $\begin{array}{c}12 / 1 / 03 \\
12: 45\end{array}$ & $\begin{array}{c}12 / 2 / 03 \\
3: 07\end{array}$ & $\begin{array}{c}12 / 2 / 03 \\
17: 25\end{array}$ & $\begin{array}{c}12 / 3 / 03 \\
8: 00\end{array}$ & $\begin{array}{c}12 / 3 / 03 \\
22: 25\end{array}$ & $\begin{array}{c}12 / 4 / 03 \\
13: 10\end{array}$ & $\begin{array}{c}12 / 5 / 03 \\
3: 30\end{array}$ & $\begin{array}{c}12 / 5 / 03 \\
17: 49\end{array}$ \\
\hline & Feed End & $\begin{array}{c}12 / 2 / 03 \\
2: 45\end{array}$ & $\begin{array}{c}12 / 2 / 03 \\
17: 07\end{array}$ & $\begin{array}{c}12 / 3 / 03 \\
7: 25\end{array}$ & $\begin{array}{c}12 / 3 / 03 \\
22: 00\end{array}$ & $\begin{array}{c}12 / 4 / 03 \\
12: 25\end{array}$ & $\begin{array}{c}12 / 5 / 03 \\
3: 10\end{array}$ & $\begin{array}{c}12 / 5 / 03 \\
17: 30\end{array}$ & $\begin{array}{c}12 / 6 / 03 \\
7: 02\end{array}$ \\
\hline & Net Slurry Feeding (hr) & 14.0 & 14.0 & 14.0 & 14.0 & 14.0 & 14.0 & 14.0 & 13.2 \\
\hline \multirow{3}{*}{ Carbon } & Type & Starch & Starch & Starch & Starch & $\begin{array}{l}\text { Polyethylene } \\
\text { glycol }\end{array}$ & $\begin{array}{l}\text { Polyethylene } \\
\text { glycol }\end{array}$ & $\begin{array}{l}\text { Polyethylene } \\
\text { glycol }\end{array}$ & $\begin{array}{l}\text { Polyethylene } \\
\text { glycol }\end{array}$ \\
\hline & Sugar ratio & 0.5 & 0.75 & 1.0 & 1.25 & 0.5 & 0.75 & 1.0 & 1.25 \\
\hline & $\begin{array}{c}\text { Mol. } \mathrm{NO}_{\mathrm{x}}: \text { Mol. Total Organic } \\
\text { Carbon }\end{array}$ & 1: 0.75 & 1: 1.13 & 1: 1.5 & 1: 1.88 & 1: 0.75 & 1: 1.13 & 1: 1.88 & 1: 1.88 \\
\hline \multirow{5}{*}{ Product } & Measured wt $\% \mathrm{SO}_{3}$ & 0.42 & 0.38 & 0.28 & 0.24 & 0.36 & 0.40 & 0.43 & 0.40 \\
\hline & \% Feed Sulfur in Glass Product & 84 & 76 & 56 & 48 & 72 & 80 & 86 & 80 \\
\hline & $\% \mathrm{Fe}^{+2}$ & $<1$ & 8 & 31 & 37 & 18 & 13 & 2 & 3 \\
\hline & Measured wt\% I & 0.01 & 0.04 & 0.04 & 0.03 & 0.01 & 0.01 & 0.01 & 0.01 \\
\hline & \% Feed I in Glass Product & 10 & 40 & 30 & 30 & 10 & 10 & 10 & 10 \\
\hline \multirow{6}{*}{$\begin{array}{c}\text { Stack } \\
\text { Emissions } \\
\text { (ppmv) }\end{array}$} & NO & 410 & 470 & 450 & 410 & 230 & 140 & 50 & \multirow{6}{*}{ NA } \\
\hline & $\mathrm{NO}_{2}$ & 42 & 49 & 41 & 30 & 4.7 & 1.3 & 1.4 & \\
\hline & $\mathrm{SO}_{2}$ & 1.3 & $<0.1$ & $<0.1$ & $<0.1$ & 3.7 & 3.8 & 9.0 & \\
\hline & $\mathrm{CO}$ & 140 & 270 & 360 & 320 & 13 & 15 & 6.5 & \\
\hline & $\mathrm{NH}_{3}$ & 11 & 7.7 & 3.4 & $<0.1$ & 440 & 680 & 380 & \\
\hline & Acetonitrile & $<0.1$ & $<0.1$ & $<0.1$ & $<0.1$ & 86 & 140 & 75 & \\
\hline
\end{tabular}


Table 3.2. Listing of DM10 Glasses Discharged, Masses, and Analysis Performed.

\begin{tabular}{|c|c|c|c|c|c|c|c|c|c|c|}
\hline $\begin{array}{l}\text { Type } \\
\text { Carbon }\end{array}$ & Test & $\begin{array}{l}\text { Sugar } \\
\text { Ratio }\end{array}$ & Date & Sample I.D. & Analysis & Glass (kg) & $\begin{array}{l}\text { Cumulative } \\
\text { Glass (kg) }\end{array}$ & $\begin{array}{l}\mathrm{SO}_{3} \\
\mathrm{wt} \%\end{array}$ & $\begin{array}{c}\mathrm{CF}^{2+} \\
/ \text { Total } \\
\text { Fe }\end{array}$ & $\begin{array}{c}\text { I } \\
\text { wt } \%\end{array}$ \\
\hline \multirow{38}{*}{ Sugar } & \multirow{9}{*}{ A1A } & \multirow{9}{*}{0.50} & \multirow{6}{*}{$11 / 17 / 03$} & 10G-G-29A & - & \multirow{2}{*}{3.92} & \multirow{2}{*}{3.92} & - & - & - \\
\hline & & & & 10G-G-29B & XRF & & & 0.48 & - & 0.01 \\
\hline & & & & 10G-G-40A & - & \multirow{2}{*}{4.46} & \multirow{2}{*}{8.38} & - & - & - \\
\hline & & & & 10G-G-40B & XRF & & & 0.47 & - & 0.01 \\
\hline & & & & 10G-G-40C & - & \multirow{2}{*}{4.70} & \multirow{2}{*}{13.08} & - & - & - \\
\hline & & & & 10G-G-40D & XRF & & & 0.46 & - & 0.02 \\
\hline & & & \multirow{14}{*}{$11 / 18 / 03$} & 10G-G-40E & - & \multirow{2}{*}{4.50} & \multirow{2}{*}{17.58} & - & - & - \\
\hline & & & & 10G-G-40F & XRF & & & 0.45 & - & 0.02 \\
\hline & & & & 10G-G-41A & - & \multirow{2}{*}{4.90} & \multirow{2}{*}{22.48} & - & - & - \\
\hline & \multirow{9}{*}{ A1B } & \multirow{9}{*}{0.75} & & 10G-G-41B & XRF & & & 0.44 & - & 0.02 \\
\hline & & & & 10G-G-45A & - & \multirow{2}{*}{3.62} & \multirow{2}{*}{26.10} & - & - & - \\
\hline & & & & 10G-G-45B & XRF & & & 0.41 & - & 0.03 \\
\hline & & & & 10G-G-45C & - & \multirow{2}{*}{4.38} & \multirow{2}{*}{30.48} & - & - & - \\
\hline & & & & 10G-G-45D & XRF, & & & 0.39 & - & 0.03 \\
\hline & & & & 10G-G-45E & - & \multirow{2}{*}{4.80} & \multirow{2}{*}{35.28} & - & - & - \\
\hline & & & & 10G-G-45F & XRF & & & 0.38 & - & 0.05 \\
\hline & & & & 10G-G-46A & XRF & 5.40 & 40.68 & 0.38 & - & 0.04 \\
\hline & & & & 10G-G-46B & - & & & - & - & - \\
\hline & & & & 10G-G-46C & XRF & 6.10 & 46.78 & 0.39 & - & 0.04 \\
\hline & & & & 10G-G-50A & - & 550 & 5228 & - & - & - \\
\hline & & & & 10G-G-50B & XRF & 5.50 & 52.28 & 0.38 & - & 0.05 \\
\hline & & & & 10G-G-50C & - & 330 & 5558 & - & - & - \\
\hline & & 100 & & 10G-G-51A & XRF & 3.30 & 55.58 & 0.34 & - & 0.05 \\
\hline & A1C & 1.00 & & 10G-G-51B & - & & 5918 & - & - & - \\
\hline & & & & 10G-G-51C & $\mathrm{XRF}, \mathrm{Fe}^{2+}$ & 3.60 & 59.18 & 0.34 & 40 & 0.04 \\
\hline & & & & 10G-G-51D & - & 382 & 6300 & - & - & - \\
\hline & & & & 10G-G-51E & $\mathrm{XRF}, \mathrm{Fe}^{2+}$ & 3.82 & 63.00 & 0.32 & 45 & 0.04 \\
\hline & & & 11 & 10G-G-55A & - & 430 & 6730 & - & - & - \\
\hline & & & $11 / 19 / 03$ & 10G-G-55B & XRF & 4.30 & 67.30 & 0.35 & - & 0.04 \\
\hline & & & & 10G-G-55C & - & 462 & 7192 & - & - & - \\
\hline & & & & 10G-G-55D & XRF & 4.62 & 71.92 & 0.32 & - & 0.04 \\
\hline & & & & 10G-G-57A & - & 522 & 7714 & - & - & - \\
\hline & A1D & 125 & & 10G-G-57B & XRF & & & 0.29 & - & 0.04 \\
\hline & A1D & 1.25 & & 10G-G-57C & - & & 8338 & - & - & - \\
\hline & & & & 10G-G-57D & $\mathrm{XRF}, \mathrm{Fe}^{2+}$ & 6.24 & 83.38 & 0.28 & 47 & 0.04 \\
\hline & & & & 10G-G-60A & - & 566 & 8904 & - & - & - \\
\hline & & & & 10G-G-60B & $\mathrm{XRF}, \mathrm{Fe}^{2+}$ & 5.66 & 89.04 & 0.29 & 55 & 0.05 \\
\hline & & & & 10G-G-60C & - & 412 & 9316 & - & - & - \\
\hline & & & $11 / 20 / 03$ & 10G-G-60D & XRF & 4.12 & 93.16 & 0.32 & - & 0.04 \\
\hline 选 & A4A & 0.75 & & 10G-G-64A & - & 426 & 9742 & - & - & - \\
\hline & & & & 10G-G-64B & XRF & 4.26 & 97.42 & 0.33 & - & 0.04 \\
\hline
\end{tabular}


Table 3.2. Listing of DM10 Glasses Discharged, Masses, and Analysis Performed (continued).

\begin{tabular}{|c|c|c|c|c|c|c|c|c|c|c|}
\hline $\begin{array}{l}\text { Type } \\
\text { Carbon }\end{array}$ & Test & $\begin{array}{l}\text { Sugar } \\
\text { Ratio }\end{array}$ & Date & Sample I.D. & Analysis & Glass (kg) & $\begin{array}{l}\text { Cumulative } \\
\text { Glass (kg) }\end{array}$ & $\begin{array}{l}\mathrm{SO}_{3} \\
\mathrm{wt} \%\end{array}$ & $\begin{array}{c}\% \mathrm{Fe}^{2+} \\
/ \mathrm{Total} \\
\mathrm{Fe}\end{array}$ & $\begin{array}{c}\text { I } \\
\text { wt } \%\end{array}$ \\
\hline \multirow{28}{*}{ 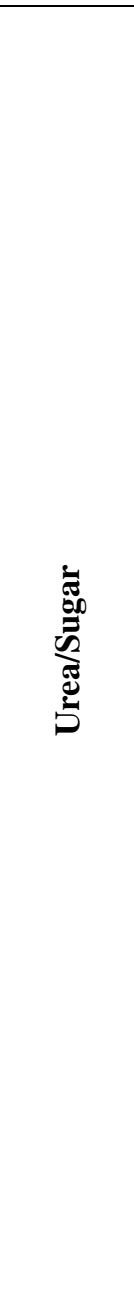 } & \multirow{6}{*}{ A4A } & \multirow{6}{*}{0.75} & \multirow{11}{*}{$11 / 20 / 03$} & 10G-G-64C & - & \multirow{2}{*}{3.62} & \multirow{2}{*}{101.04} & - & - & - \\
\hline & & & & 10G-G-64D & XRF & & & 0.37 & - & 0.04 \\
\hline & & & & 10G-G-64E & - & \multirow{2}{*}{4.70} & \multirow{2}{*}{105.74} & - & - & - \\
\hline & & & & 10G-G-65A & XRF & & & 0.38 & - & 0.04 \\
\hline & & & & 10G-G-65B & - & \multirow{2}{*}{3.14} & \multirow{2}{*}{108.88} & - & - & - \\
\hline & & & & 10G-G-65C & XRF, $\mathrm{Fe}^{2+}$ & & & 0.39 & 3 & 0.05 \\
\hline & \multirow{11}{*}{ A4B } & \multirow{11}{*}{1.00} & & 10G-G-65D & - & \multirow{2}{*}{4.92} & \multirow{2}{*}{113.80} & - & - & - \\
\hline & & & & 10G-G-69A & XRF & & & 0.38 & - & 0.04 \\
\hline & & & & 10G-G-69B & - & \multirow{2}{*}{5.24} & \multirow{2}{*}{119.04} & - & - & - \\
\hline & & & & 10G-G-69C & XRF & & & 0.37 & - & 0.04 \\
\hline & & & & 10G-G-69D & - & \multirow{2}{*}{4.00} & \multirow{2}{*}{123.04} & - & - & - \\
\hline & & & \multirow{16}{*}{$11 / 21 / 03$} & 10G-G-69E & XRF & & & 0.37 & - & 0.04 \\
\hline & & & & 10G-G-69F & - & \multirow{2}{*}{3.26} & \multirow{2}{*}{126.30} & - & - & - \\
\hline & & & & 10G-G-70A & XRF & & & 0.34 & - & 0.04 \\
\hline & & & & 10G-G-70B & - & \multirow{2}{*}{3.68} & \multirow{2}{*}{129.98} & - & - & - \\
\hline & & & & 10G-G-70C & XRF, $\mathrm{Fe}^{2+}$ & & & 0.34 & 19 & 0.04 \\
\hline & & & & 10G-G-70D & - & 324 & 22 133 & - & - & - \\
\hline & & & & 10G-G-75A & XRF & 3.24 & 133.22 & 0.32 & - & 0.03 \\
\hline & & & & 10G-G-75B & - & 328 & 13650 & - & - & - \\
\hline & & & & 10G-G-76A & XRF & 3.28 & 136.50 & 0.34 & - & 0.04 \\
\hline & & & & 10G-G-76B & - & & & - & - & - \\
\hline & & & & 10G-G-77A & $\mathrm{XRF}, \mathrm{Fe}^{2+}$ & 4.00 & 140.50 & 0.35 & 27 & 0.03 \\
\hline & A4C & 1.25 & & 10G-G-77B & - & 407 & 14452 & - & - & - \\
\hline & & & & 10G-G-77C & XRF, $\mathrm{Fe}^{2+}$ & 4.02 & 144.52 & 0.35 & 25 & 0.03 \\
\hline & & & & 10G-G-77D & - & & 14808 & - & - & - \\
\hline & & & & 10G-G-80A & XRF, $\mathrm{Fe}^{2+}$ & 3.56 & 148.08 & 0.33 & 27 & 0.03 \\
\hline & & & & 10G-G-80B & - & & & - & - & - \\
\hline & & & $11 / 22 / 03$ & 10G-G-80C & XRF, $\mathrm{Fe}^{2+}$ & 3.80 & 151.88 & 0.52 & 29 & 0.04 \\
\hline & & & & 10G-G-96A & - & 326 & 15514 & - & - & - \\
\hline & & & & 10G-G-96B & XRF & 3.26 & 155.14 & 0.43 & - & $<0.01$ \\
\hline & & & & 10G-G-96C & - & 436 & 15050 & - & - & - \\
\hline & & & & 10G-G-96D & XRF & 4.36 & 159.50 & 0.42 & - & 0.01 \\
\hline & & & $12 / 1 / 03$ & 10G-G-96E & - & 368 & 16318 & - & - & - \\
\hline$\overline{0}$ & A2A & 0.50 & $12 / 1 / 03$ & 10G-G-97A & XRF, $\mathrm{Fe}^{2+}$ & 3.68 & 163.18 & 0.40 & $<1$ & 0.01 \\
\hline कै & & & & 10G-G-97B & - & 362 & 16680 & - & - & - \\
\hline & & & & 10G-G-97C & XRF & 3.62 & 166.80 & 0.42 & - & 0.01 \\
\hline & & & & 10G-G-97D & - & 710 & 7300 & - & - & - \\
\hline & & & & \begin{tabular}{|l|} 
10G-G-97E \\
\end{tabular} & XRF, $\mathrm{Fe}^{2+}$ & 7.10 & 173.90 & 0.40 & $<1$ & 0.01 \\
\hline & & & ח/2/12 & 10G-G-100A & - & 200 & 175 on & - & - & - \\
\hline & A2B & 0.75 & & 10G-G-100B & XRF & 2.00 & $1 / 5.90$ & 0.42 & - & 0.01 \\
\hline
\end{tabular}

\footnotetext{
"-" Empty data field
} 
Table 3.2. Listing of DM10 Glasses Discharged, Masses, and Analysis Performed (continued).

\begin{tabular}{|c|c|c|c|c|c|c|c|c|c|}
\hline \begin{tabular}{|c|} 
Type \\
Carbon
\end{tabular} & Test & $\begin{array}{l}\text { Sugar } \\
\text { Ratio }\end{array}$ & Date & Sample I.D. & $\begin{array}{c}\text { Glass } \\
\text { (kg) }\end{array}$ & $\begin{array}{c}\text { Cumulative } \\
\text { Glass (kg) }\end{array}$ & $\begin{array}{r}\mathrm{SO}_{3} \\
\mathrm{wt} \% \\
\end{array}$ & $\begin{array}{c}\% \mathrm{Fe}^{2+} \\
/ \text { Total Fe }\end{array}$ & I wt \% \\
\hline \multirow{32}{*}{$\begin{array}{l}\overline{0} \\
\bar{E} \\
\tilde{D}\end{array}$} & \multirow{10}{*}{ A2B } & \multirow{10}{*}{0.75} & \multirow{16}{*}{$12 / 2 / 03$} & 10G-G-100C & \multirow{2}{*}{5.06} & \multirow{2}{*}{180.96} & - & - & - \\
\hline & & & & 10G-G-100D & & & 0.37 & - & 0.03 \\
\hline & & & & 10G-G-102A & \multirow{2}{*}{3.24} & \multirow{2}{*}{184.20} & - & - & - \\
\hline & & & & 10G-G-102B & & & 0.36 & - & 0.04 \\
\hline & & & & 10G-G-102C & \multirow{2}{*}{3.96} & \multirow{2}{*}{188.16} & - & - & - \\
\hline & & & & 10G-G-103A & & & 0.36 & - & 0.04 \\
\hline & & & & 10G-G-103B & \multirow{2}{*}{3.47} & \multirow{2}{*}{191.63} & - & - & - \\
\hline & & & & 10G-G-103C & & & 0.37 & - & 0.04 \\
\hline & & & & 10G-G-103D & \multirow{2}{*}{3.74} & \multirow{2}{*}{195.37} & - & - & - \\
\hline & & & & 10G-G-103E & & & 0.38 & 8 & 0.04 \\
\hline & \multirow{12}{*}{ A2C } & \multirow{12}{*}{1.00} & & 10G-G-106A & \multirow{2}{*}{3.74} & \multirow{2}{*}{199.11} & - & - & - \\
\hline & & & & 10G-G-106B & & & 0.36 & - & 0.04 \\
\hline & & & & 10G-G-106C & \multirow{2}{*}{4.20} & \multirow{2}{*}{203.31} & - & - & - \\
\hline & & & & 10G-G-106D & & & 0.34 & - & 0.04 \\
\hline & & & & 10G-G-106E & \multirow{2}{*}{4.06} & \multirow{2}{*}{207.37} & - & - & - \\
\hline & & & & 10G-G-106F & & & 0.31 & 30 & 0.04 \\
\hline & & & & 10G-G-108A & \multirow{2}{*}{4.50} & 21187 & - & - & - \\
\hline & & & & 10G-G-108B & & 211.01 & 0.29 & - & 0.04 \\
\hline & & & & 10G-G-108C & 350 & 21537 & - & - & - \\
\hline & & & & 10G-G-108D & 3.50 & / & 0.27 & - & 0.03 \\
\hline & & & & 10G-G-108E & & 2195 & - & - & - \\
\hline & & & & 10G-G-108F & 4.20 & $219.5 /$ & 0.28 & 31 & 0.03 \\
\hline & & & & 10G-G-113A & & & - & - & - \\
\hline & & & & 10G-G-113B & 4.30 & $223.8 /$ & 0.27 & - & 0.03 \\
\hline & & & $12 / 3 / 03$ & 10G-G-113C & 400 & 27787 & - & - & - \\
\hline & & & & 10G-G-113D & 4.00 & 227.07 & 0.27 & - & 0.03 \\
\hline & מרני & 125 & & 10G-G-113E & 450 & 323 & - & - & - \\
\hline & A2U & 1.20 & & 10G-G-114A & 4.50 & $232.3 /$ & 0.25 & - & 0.03 \\
\hline & & & & 10G-G-114B & 424 & 23661 & - & - & - \\
\hline & & & & 10G-G-114C & 4.24 & 230.01 & 0.25 & - & 0.03 \\
\hline & & & & 10G-G-114D & & 241.15 & - & - & - \\
\hline & & & & 10G-G-114E & 4.54 & 241.15 & 0.24 & 37 & 0.03 \\
\hline & & & & 10G-G-115A & & & - & - & - \\
\hline & & & & 10G-G-119A & 4.70 & 245.85 & 0.28 & - & 0.03 \\
\hline$\overline{8}$ & & & & 10G-G-119B & 430 & 25015 & - & - & - \\
\hline$\frac{2}{00}$ & & & & 10G-G-119C & 4.30 & 250.15 & 0.34 & - & 0.02 \\
\hline Ё & A3A & 0.50 & & 10G-G-123A & 420 & 25435 & - & - & - \\
\hline$\frac{2}{3}$ & & & $12 / 4 / 03$ & 10G-G-123B & 4.20 & 254.35 & 0.35 & 21 & 0.01 \\
\hline$\sum_{2}^{2}$ & & & & 10G-G-123C & & 25815 & - & - & - \\
\hline$\frac{2}{2}$ & & & & 10G-G-124A & 3.80 & 258.15 & 0.36 & 18 & 0.01 \\
\hline & & & & 10G-G-124B & 4.08 & 262.23 & - & - & - \\
\hline & A3B & 0.75 & & 10G-G-124C & 4.08 & 202.23 & 39 & - & $<0.01$ \\
\hline
\end{tabular}

"-" Empty data field 
Table 3.2. Listing of DM10 Glasses Discharged, Masses, and Analysis Performed (continued).

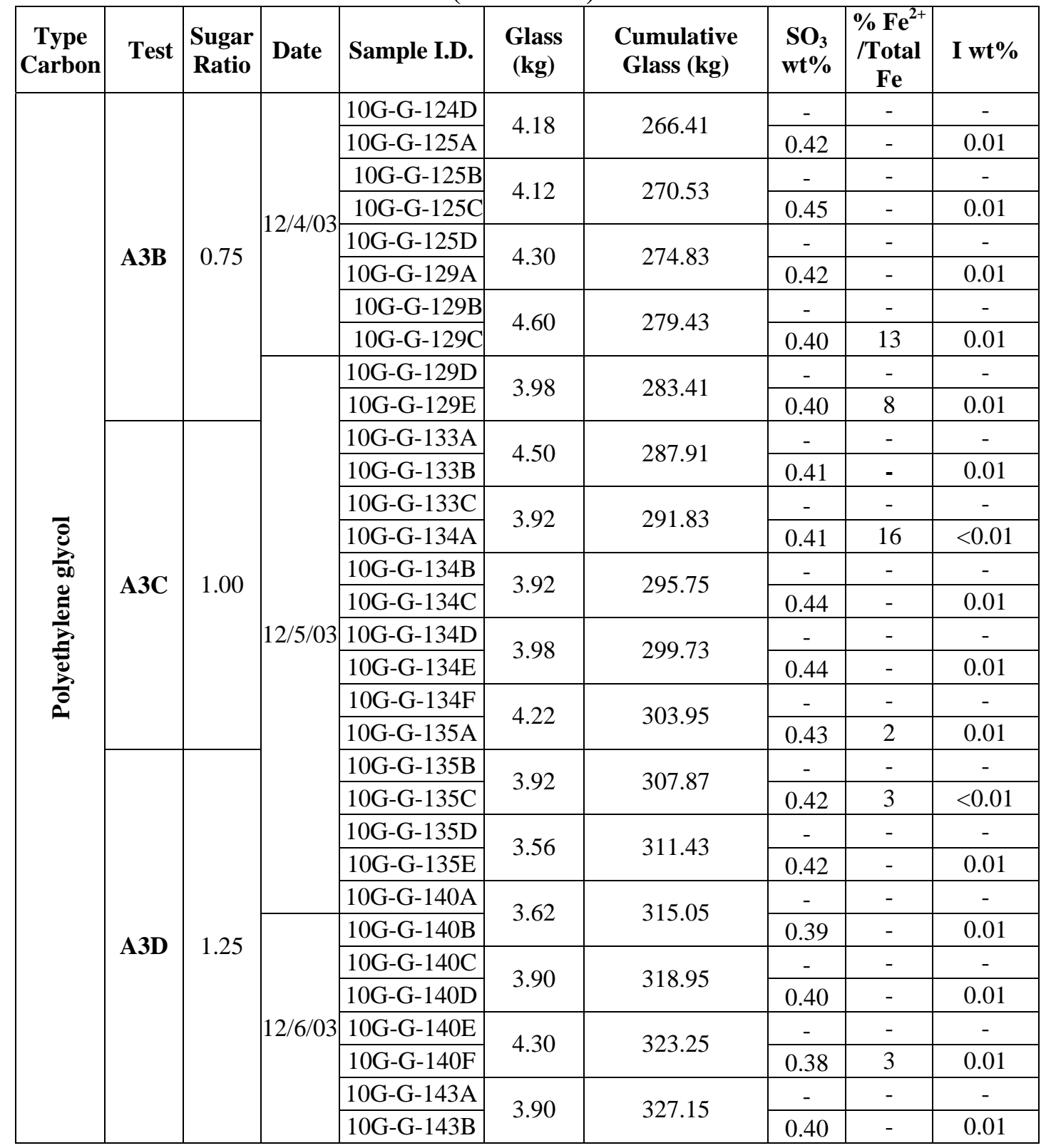

"-" Empty data field 
Table 4.1. Summary of DM100 Test Conditions and Results.

\begin{tabular}{|c|c|c|c|c|c|}
\hline \multicolumn{3}{|c|}{ - } & $\begin{array}{l}\text { Urea and } \\
\text { Sugar Test }\end{array}$ & $\begin{array}{c}\text { Vanadium } \\
\text { Additive } \\
\text { Test }\end{array}$ & $\begin{array}{l}\text { Starch and } \\
\text { Sugar Test }\end{array}$ \\
\hline \multirow{5}{*}{ Time } & \multicolumn{2}{|c|}{ Feed Start } & $\begin{array}{c}12 / 10 / 03 \\
10: 15\end{array}$ & $\begin{array}{c}12 / 16 / 03 \\
18: 30\end{array}$ & $\begin{array}{c}1 / 28 / 04 \\
9: 45\end{array}$ \\
\hline & \multicolumn{2}{|c|}{ Feed End } & $\begin{array}{c}12 / 12 / 03 \\
21 \cdot 31\end{array}$ & $\begin{array}{c}12 / 19 / 03 \\
5 \cdot 14\end{array}$ & $1 / 30 / 04$ \\
\hline & \multicolumn{2}{|c|}{ Water Feeding (hr) } & 1.0 & 1.0 & 1.0 \\
\hline & \multicolumn{2}{|c|}{ Net Slurry Feeding (hr) } & 58.3 & 57.7 & 50.8 \\
\hline & \multicolumn{2}{|c|}{ Cold Cap Burn-Off (hr) } & 1.5 & 4.6 & 1.7 \\
\hline \multirow{5}{*}{ Carbon } & \multirow{3}{*}{$\begin{array}{c}\text { Type } \\
\text { (g/ kg feed) }\end{array}$} & Waste Organics & 4.34 & 4.34 & 8.95 \\
\hline & & Sugar & 33.1 & 33.1 & 17.2 \\
\hline & & Other & Urea: 74.2 & 0 & Starch: 27.4 \\
\hline & \multicolumn{2}{|c|}{ Stoichiometric ratio } & $1.0^{*}$ & $0.5^{*}$ & $0.75^{\#}$ \\
\hline & \multicolumn{2}{|c|}{$\begin{array}{c}\text { Mol. } \mathrm{NO}_{\mathrm{x}} \text { : Mol. Total Organic } \\
\text { Carbon }\end{array}$} & 1: 1.5 & 1: 0.75 & 1: 1.13 \\
\hline \multicolumn{3}{|c|}{ Feed Used (kg) } & 942 & 980 & 841 \\
\hline \multicolumn{3}{|c|}{ Average Production Rate $\left(\mathrm{kg} / \mathrm{m}^{2} /\right.$ day $)$} & 1860 & 1951 & 1902 \\
\hline \multicolumn{3}{|c|}{ Average Bubbling Rate (lpm) } & 22.1 & 22.5 & 16.4 \\
\hline \multirow{3}{*}{ Product } & \multicolumn{2}{|c|}{ Measured wt $\% \mathrm{SO}_{3}$} & 0.33 & 0.39 & 0.35 \\
\hline & \multicolumn{2}{|c|}{ \% Feed Sulfur in Glass Product } & 66 & 78 & 70 \\
\hline & \multicolumn{2}{|c|}{$\% \mathrm{Fe}^{+2} /$ Total Iron } & 23 & 3 & 24 \\
\hline \multicolumn{3}{|c|}{ \% Feed Sulfur in Particulate Emissions } & 15.9 & 14.4 & 30.4 \\
\hline \multicolumn{3}{|c|}{ \% Feed Sulfur in Gaseous Emissions } & 7.6 & 0.4 & 13.6 \\
\hline \multirow{2}{*}{$\mathrm{NO}_{\mathrm{x}}$} & \multicolumn{2}{|c|}{ NO: $\mathrm{NO}_{2}$} & 43 & 10 & 35 \\
\hline & \multicolumn{2}{|c|}{$\%$ Feed $\mathrm{NO}_{\mathrm{x}}$ emitted as $\mathrm{NO}_{\mathrm{x}}$} & 22.5 & 55.8 & 33.5 \\
\hline
\end{tabular}

* - Sugar is at 0.5 stoichiometry.

\# - Sugar is at 0.25 stoichiometry.

"-" Empty data field 
The Catholic University of America Vitreous State Laboratory
Glass Formulation Testing to Increase Sulfate Volatilization

Final Report, VSL-04R4970-1, Rev. 0

Table 4.2. Summary of Measured DM100 Parameters.

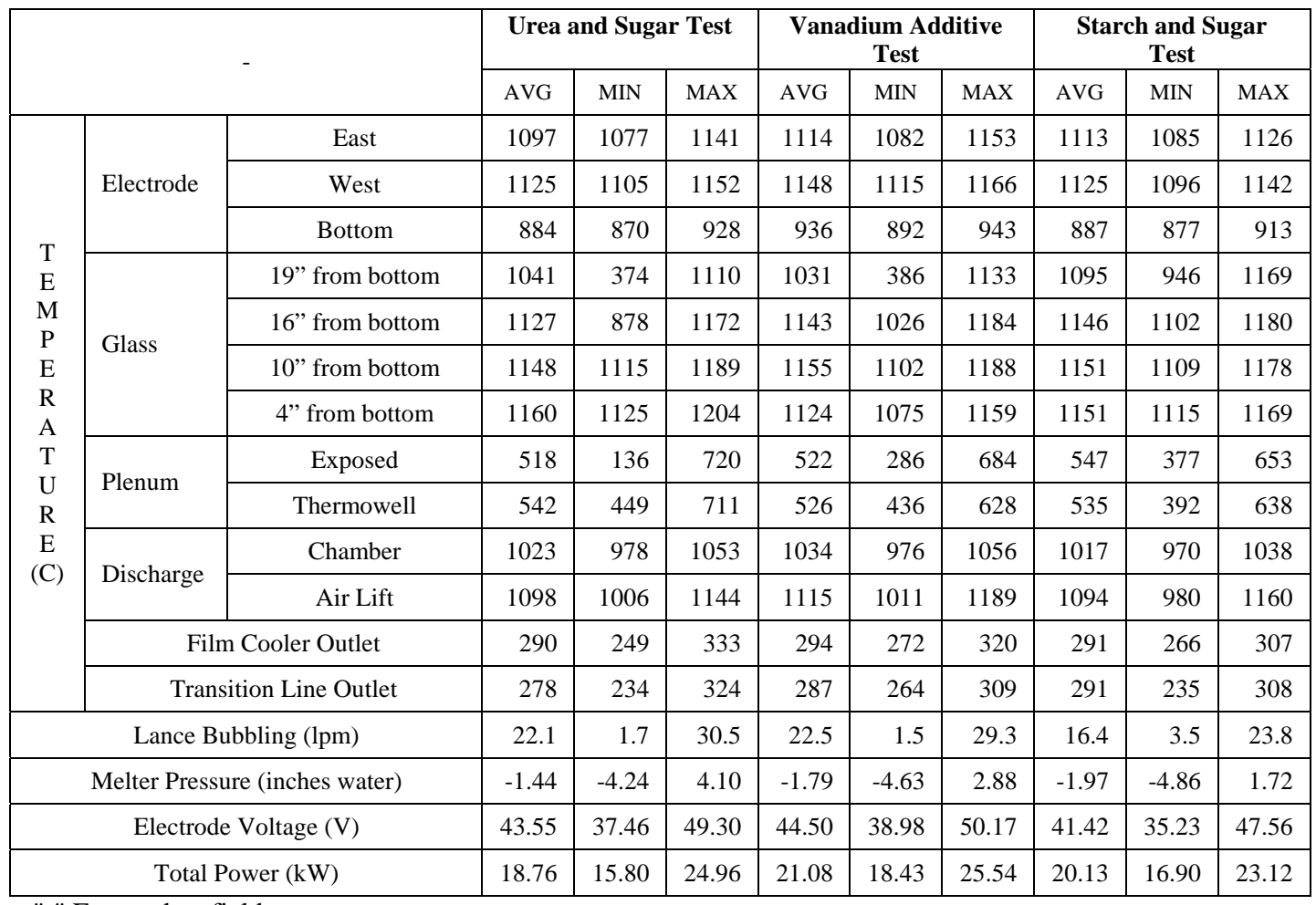

"-" Empty data field 
Table 5.1. Listing of DM100 Glasses Discharged, Masses, and Analysis Performed.

\begin{tabular}{|c|c|c|c|c|c|c|}
\hline Test & Date & Sample I.D. & Analysis & Mass (kg) & \begin{tabular}{|c|} 
Cumulative \\
Mass Per Test \\
(kg) \\
\end{tabular} & $\begin{array}{c}\text { Cumulative } \\
\text { Mass (kg) }\end{array}$ \\
\hline \multirow{43}{*}{ 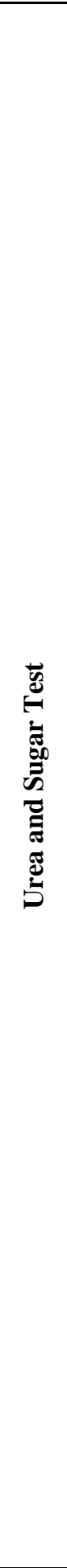 } & \multirow{7}{*}{$12 / 10 / 03$} & WVU-G-54A & - & \multirow{2}{*}{22.44} & \multirow{2}{*}{22.44} & \multirow{2}{*}{22.44} \\
\hline & & WVU-G-55A & XRF & & & \\
\hline & & WVU-G-55B & - & \multirow{3}{*}{26.50} & \multirow{3}{*}{48.94} & \multirow{3}{*}{48.94} \\
\hline & & WVU-G-57A & - & & & \\
\hline & & WVU-G-57B & XRF & & & \\
\hline & & WVU-G-59A & - & \multirow{2}{*}{22.20} & \multirow{2}{*}{71.14} & \multirow{2}{*}{71.14} \\
\hline & & WVU-G-59B & XRF & & & \\
\hline & \multirow{25}{*}{$12 / 11 / 03$} & WVU-G-62A & - & \multirow{2}{*}{18.40} & \multirow{2}{*}{89.54} & \multirow{2}{*}{89.54} \\
\hline & & WVU-G-62B & XRF & & & \\
\hline & & WVU-G-64A & - & \multirow{2}{*}{21.90} & \multirow{2}{*}{111.44} & \multirow{2}{*}{111.44} \\
\hline & & WVU-G-64B & XRF & & & \\
\hline & & WVU-G-64C & - & \multirow{2}{*}{14.30} & \multirow{2}{*}{125.74} & \multirow{2}{*}{125.74} \\
\hline & & WVU-G-65A & XRF & & & \\
\hline & & WVU-G-65B & - & \multirow{4}{*}{25.46} & \multirow{4}{*}{151.20} & \multirow{4}{*}{151.20} \\
\hline & & WVU-G-65C & - & & & \\
\hline & & WVU-G-66A & - & & & \\
\hline & & WVU-G-66B & XRF & & & \\
\hline & & WVU-G-66C & - & & & \\
\hline & & WVU-G-66D & - & 1720 & 16840 & 16840 \\
\hline & & WVU-G-66E & - & $1 / .20$ & 168.40 & 168.40 \\
\hline & & WVU-G-70A & XRF & & & \\
\hline & & WVU-G-70B & - & & & \\
\hline & & WVU-G-70C & - & 300 & 19847 & 19847 \\
\hline & & WVU-G-71A & - & 50.02 & 198.42 & 198.42 \\
\hline & & WVU-G-71B & XRF & & & \\
\hline & & WVU-G-73A & - & & & \\
\hline & & WVU-G-73B & - & 21.34 & 219.76 & 219.76 \\
\hline & & WVU-G-73C & $\mathrm{XRF}$ & & & \\
\hline & & WVU-G-73D & - & & & \\
\hline & & WVU-G-75A & - & 24.62 & 244.38 & 244.38 \\
\hline & & WVU-G-75B & XRF & & & \\
\hline & & WVU-G-75C & - & & & \\
\hline & & WVU-G-75D & - & 20.98 & 265.36 & 265.36 \\
\hline & & WVU-G-79A & XRF & & & \\
\hline & & WVU-G-79B & - & & & \\
\hline & & WVU-G-79C & - & 17.80 & 283.16 & 283.16 \\
\hline & & WVU-G-80A & XRF & & & \\
\hline & $12 / 12 / 03$ & WVU-G-80B & - & & & \\
\hline & & WVU-G-80C & - & 27.20 & 310.36 & 310.36 \\
\hline & & WVU-G-81A & $\mathrm{XRF}$ & & & \\
\hline & & WVU-G-81B & - & & & \\
\hline & & WVU-G-83A & - & 23.60 & 333.96 & 333.96 \\
\hline & & WVU-G-84A & XRF & & & \\
\hline
\end{tabular}

"-" Empty data field 
Table 5.1. Listing of DM100 Glasses Discharged, Masses, and Analysis Performed (continued).

\begin{tabular}{|c|c|c|c|c|c|c|}
\hline Test & Date & Sample I.D. & Analysis & Mass (kg) & \begin{tabular}{|c|} 
Cumulative \\
Mass Per Test \\
(kg )
\end{tabular} & \begin{tabular}{|c} 
Cumulative \\
Mass (kg)
\end{tabular} \\
\hline \multirow{11}{*}{ 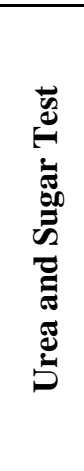 } & \multirow{11}{*}{$12 / 12 / 03$} & WVU-G-84B & - & \multirow{3}{*}{27.00} & \multirow{3}{*}{360.96} & \multirow{3}{*}{360.96} \\
\hline & & WVU-G-85A & - & & & \\
\hline & & WVU-G-85B & XRF & & & \\
\hline & & WVU-G-85C & - & \multirow{3}{*}{31.45} & \multirow{3}{*}{392.41} & \multirow{3}{*}{392.41} \\
\hline & & \begin{tabular}{|l|} 
WVU-G-88A \\
\end{tabular} & - & & & \\
\hline & & \begin{tabular}{|l|} 
WVU-G-88B \\
\end{tabular} & XRF & & & \\
\hline & & \begin{tabular}{|l|} 
WVU-G-88C \\
\end{tabular} & - & \multirow{4}{*}{27.64} & \multirow{4}{*}{420.05} & \multirow{4}{*}{420.05} \\
\hline & & WVU-G-88D & - & & & \\
\hline & & WVU-G-89A & - & & & \\
\hline & & WVU-G-89B & XRF & & & \\
\hline & & WVU-G-89C & XRF, DCP & 12.70 & 432.75 & 432.75 \\
\hline \multirow{33}{*}{ 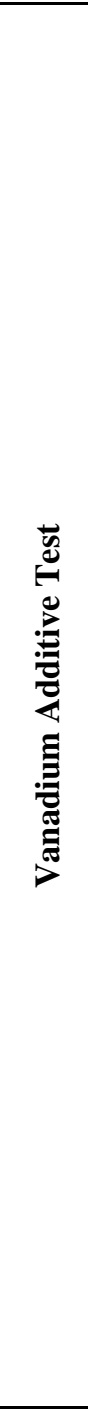 } & \multirow{2}{*}{$12 / 16 / 03$} & WVU-G-130A & - & \multirow{2}{*}{24.10} & \multirow{2}{*}{24.10} & \multirow[b]{2}{*}{456.85} \\
\hline & & WVU-G-130B & $\mathrm{XRF}, \mathrm{Fe}^{2+}$ & & & \\
\hline & \multirow{19}{*}{$12 / 17 / 03$} & WVU-G-140A & \begin{tabular}{|c|}
- \\
\end{tabular} & \multirow{2}{*}{25.20} & \multirow{2}{*}{49.30} & \multirow{2}{*}{482.05} \\
\hline & & WVU-G-140B & XRF & & & \\
\hline & & WVU-G-140C & \begin{tabular}{|l|}
- \\
\end{tabular} & \multirow{2}{*}{24.10} & \multirow{2}{*}{73.40} & \multirow{2}{*}{506.15} \\
\hline & & WVU-G-141A & $\mathrm{XRF}, \mathrm{Fe}^{2+}$ & & & \\
\hline & & WVU-G-141B & - & & & \\
\hline & & WVU-G-141C & XRF & 21.50 & 94.90 & 527.65 \\
\hline & & WVU-G-143A & - & 1800 & م9 112 & 54565 \\
\hline & & WVU-G-146A & XRF & 18.00 & 112.90 & 545.65 \\
\hline & & WVU-G-146B & - & & & \\
\hline & & WVU-G-146C & - & 25.20 & 138.10 & 570.85 \\
\hline & & WVU-G-147A & XRF & & & \\
\hline & & WVU-G-147B & - & & & \\
\hline & & WVU-G-148A & XRF & 23.30 & 161.40 & 594.15 \\
\hline & & WVU-G-148B & - & & & \\
\hline & & WVU-G-152A & XRF & 21.24 & 182.64 & 615.39 \\
\hline & & WVU-G-152B & - & & & \\
\hline & & WVU-G-152C & XRF & 23.48 & 206.12 & 638.87 \\
\hline & & WVU-G-153A & - & 56 & 23868 & 66143 \\
\hline & & WVU-G-153B & XRF & 22.56 & 220.00 & 601.43 \\
\hline & & WVV-G-6A & - & 2160 & 25038 & 68303 \\
\hline & & WVV-G-6B & XRF, $\mathrm{Fe}^{2+}$ & 21.60 & 250.28 & 683.03 \\
\hline & & WVV-G-8A & \begin{tabular}{|l|}
- \\
\end{tabular} & 2010 & 27038 & 70313 \\
\hline & & WVV-G-8B & XRF & 20.10 & 270.38 & 703.13 \\
\hline & & WVV-G-8C & - & & & \\
\hline & & WVV-G-8D & XRF & 11.00 & 281.38 & 714.13 \\
\hline & $12 / 18 / 03$ & WVV-G-11A & - & ח0 כ2 & 30428 & 73703 \\
\hline & & WVV-G-13A & XRF & 22.90 & 304.28 & 737.03 \\
\hline & & WVV-G-13B & - & & & \\
\hline & & WVV-G-13C & XRF & 21.00 & 325.28 & 758.03 \\
\hline & & WVV-G-14A & - & & & \\
\hline & & WVV-G-14B & XRF, $\mathrm{Fe}^{2+}$ & 25.90 & 351.18 & 783.93 \\
\hline
\end{tabular}

"-" Empty data cell 
Table 5.1. Listing of DM100 Glasses Discharged, Masses, and Analysis Performed (continued).

\begin{tabular}{|c|c|c|c|c|c|c|}
\hline Test & Date & Sample I.D. & Analysis & Mass (kg) & $\begin{array}{c}\text { Cumulative } \\
\text { Mass Per Test } \\
\text { (kg) }\end{array}$ & $\begin{array}{l}\text { Cumulative } \\
\text { Mass (kg) }\end{array}$ \\
\hline \multirow{12}{*}{ 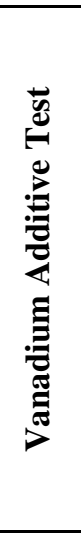 } & \multirow{8}{*}{$12 / 18 / 03$} & $\frac{\text { WVV-G-15A }}{\text { WVV-G-15B }}$ & $\frac{-}{\mathrm{XRF}}$ & 18.1 & 369.28 & 802.0 \\
\hline & & WVV-G-18A & $\begin{array}{l}\Delta \mathrm{R} F \\
-\end{array}$ & \multirow{2}{*}{24.4} & \multirow{2}{*}{393.68} & \multirow{2}{*}{826.4} \\
\hline & & WVV-G-18B & XRF & & & \\
\hline & & WVV-G-18C & - & \multirow{3}{*}{22.14} & \multirow{3}{*}{415.82} & \multirow{3}{*}{848.6} \\
\hline & & WVV-G-19A & - & & & \\
\hline & & WVV-G-19B & XRF, Fe ${ }^{2+}$ & & & \\
\hline & & WVV-G-19C & - & \multirow{2}{*}{24.3} & \multirow{2}{*}{440.12} & \multirow{2}{*}{872.9} \\
\hline & & $\frac{W V V-G-19 D}{\text { WVV-G-23A }}$ & XRF & & & \\
\hline & \multirow{4}{*}{$12 / 19 / 03$} & WVV-G-23B & - & \multirow{2}{*}{27.9} & \multirow{2}{*}{468.02} & \multirow{2}{*}{900.8} \\
\hline & & WVV-G-26A & XRF. DCP & & & \\
\hline & & WVV-G-27A & - & 29.3 & 497.32 & 930.1 \\
\hline & & WVV-G-29A & XRF. & 23.5 & 457.02 & SDO.1 \\
\hline \multirow{28}{*}{ 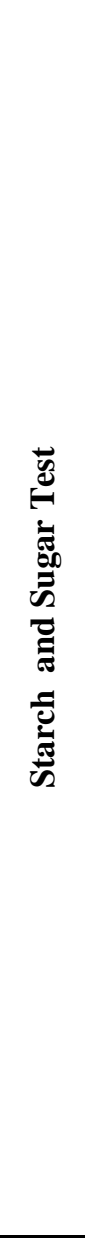 } & \multirow{7}{*}{$01 / 28 / 04$} & WVV-G-54A & $\begin{array}{l}- \\
\mathrm{XPF}\end{array}$ & 23.10 & \multirow[t]{2}{*}{23.10} & 953.17 \\
\hline & & $\frac{\text { WVV-G-54B }}{\text { WVV-G-54C }}$ & $\frac{\text { XRF }}{-}$ & \multirow[b]{2}{*}{19.60} & & \\
\hline & & WVV-G-59A & XRF & & 42.70 & 972.77 \\
\hline & & WVV-G-59B & - & 27.80 & 70.50 & 1000.57 \\
\hline & & WVV-G-60A & XRF & & & \\
\hline & & WVV-G-60B & - & 28.40 & 98.90 & 1028.97 \\
\hline & & WVV-G-61A & XRF & & & \\
\hline & & WVV-G-65A & - & 23.50 & 122.40 & 1052.47 \\
\hline & & WVV-G-65B & XRF & 25.00 & $12 \angle .40$ & 1002.47 \\
\hline & & $\begin{array}{l}\text { WVV-G-66A } \\
\text { WVV-G-66B }\end{array}$ & $\frac{-}{\mathrm{XRF}}$ & 26.10 & 148.50 & 1078.57 \\
\hline & & WVV-G-67A & - & 2020 & 16870 & 109877 \\
\hline & & WVV-G-67B & XRF & 20.20 & 100.70 & $1050.1 / 1$ \\
\hline & & $\frac{\text { WVV-G-67C }}{\text { WVV-G-67D }}$ & $\frac{-}{\mathrm{XRF}}$ & 25.60 & 194.30 & 1124.37 \\
\hline & 01/29/04 & WVV-G-69A & - & 3330 & 23760 & 115767 \\
\hline & & WVV-G-69B & XRF & S3.00 & 22.00 & $110 \%$ \\
\hline & & WVV-G-74A & $\frac{-}{4 D \Gamma}$ & 25.28 & 252.88 & 1182.95 \\
\hline & & $\frac{W V V-G-74 B}{W V V-G-75 A}$ & $\frac{\lambda \mathrm{KF}}{-}$ & 2760 & & \\
\hline & & WVV-G-78A & XRF & $2 \% .00$ & 280.48 & 1210.55 \\
\hline & & WVV-G-79A & - & 26.40 & 306.88 & 1236.95 \\
\hline & & WVV-G-81A & XRF & & & \\
\hline & & WVV-G-81B & - & 25.40 & 332.28 & 1262.35 \\
\hline & & WVV-G-82A & XRF & & & \\
\hline & & WVV-G-82B & $\frac{-}{\mathrm{XRF}}$ & 20.20 & 352.48 & 1282.55 \\
\hline & 01/30/04 & WVV-G-86A & & & & \\
\hline & & WVV-G-86B & XRF & 21.00 & $3 / 4.20$ & 1304.35 \\
\hline & & WVV-G-86C & & 28.28 & 402.56 & 1332.63 \\
\hline & & WVV-G-87A & XRF & & & \\
\hline & & WVV-G-87B & XRF, DCP & 15.70 & 418.26 & 1348.33 \\
\hline
\end{tabular}


Table 5.2. XRF Analyzed Composition for DM100 Discharged Glass Samples (wt\%).

\begin{tabular}{|c|c|c|c|c|c|c|c|c|c|c|c|c|c|c|c|c|c|}
\hline & \multicolumn{17}{|c|}{ Urea and Sugar Test } \\
\hline \multicolumn{2}{|l|}{ Glass (kg) } & 22.44 & 48.94 & 71.14 & 89.54 & 111.44 & 125.74 & 151.20 & 168.40 & 198.42 & 219.76 & 244.38 & 265.36 & 283.16 & 310.36 & 333.96 & 360.96 \\
\hline \multirow{2}{*}{ Element } & \multirow{2}{*}{ Target } & WVU- & WVU- & WVU- & WVU- & WVU- & WVU- & WVU- & WVU- & WVU- & WVU- & WVU- & WVU- & WVU- & WVU- & WVU- & WVU- \\
\hline & & $\mathrm{G}-55 \mathrm{~A}$ & G-57B & G-59B & G-62A & G-64B & G-65A & G-66B & G-70A & G-71B & G-73C & G-75B & G-79A & $\mathrm{G}-80 \mathrm{~A}$ & G-81A & G-84A & G-85B \\
\hline $\mathrm{Al}_{2} \mathrm{O}_{3}$ & 6.15 & 6.93 & 6.53 & 6.60 & 6.51 & 6.26 & 6.26 & 6.08 & 6.09 & 6.12 & 6.41 & 6.12 & 6.22 & 6.08 & 5.99 & 5.92 & 5.99 \\
\hline $\mathrm{B}_{2} \mathrm{O}_{3} *$ & 8.91 & 8.91 & 8.91 & 8.91 & 8.91 & 8.91 & 8.91 & 8.91 & 8.91 & 8.91 & 8.91 & 8.91 & 8.91 & 8.91 & 8.91 & 8.91 & 8.91 \\
\hline $\mathrm{CaO}$ & 1.99 & 1.92 & 1.94 & 1.89 & 1.90 & 1.91 & 1.85 & 1.91 & 1.90 & 1.89 & 1.92 & 1.91 & 1.91 & 1.88 & 1.95 & 1.94 & 1.93 \\
\hline $\mathrm{CdO}$ & $\S$ & $<0.01$ & $<0.01$ & $<0.01$ & $<0.01$ & $<0.01$ & $<0.01$ & $<0.01$ & $<0.01$ & $<0.01$ & $<0.01$ & $<0.01$ & $<0.01$ & $<0.01$ & $<0.01$ & $<0.01$ & $<0.01$ \\
\hline $\mathrm{Cl}$ & 0.56 & 0.15 & 0.20 & 0.21 & 0.22 & 0.23 & 0.24 & 0.25 & 0.26 & 0.28 & 0.27 & 0.27 & 0.28 & 0.27 & 0.30 & 0.30 & 0.28 \\
\hline $\mathrm{Cr}_{2} \mathrm{O}_{3}$ & 0.02 & 0.19 & 0.16 & 0.14 & 0.13 & 0.11 & 0.10 & 0.10 & 0.09 & 0.09 & 0.08 & 0.07 & 0.07 & 0.07 & 0.07 & 0.06 & 0.07 \\
\hline $\mathrm{Cs}_{2} \mathrm{O}$ & 0.15 & 0.04 & 0.07 & 0.09 & 0.10 & 0.12 & 0.12 & 0.13 & 0.12 & 0.13 & 0.14 & 0.16 & 0.16 & 0.16 & 0.17 & 0.16 & 0.16 \\
\hline $\mathrm{Fe}_{2} \mathrm{O}_{3}$ & 6.93 & 6.53 & 6.67 & 6.47 & 6.43 & 6.46 & 6.29 & 6.58 & 6.55 & 6.51 & 6.47 & 6.66 & 6.47 & 6.44 & 6.82 & 6.69 & 6.69 \\
\hline $\mathrm{I}$ & $\S$ & $<0.01$ & $<0.01$ & $<0.01$ & $<0.01$ & $<0.01$ & $<0.01$ & $<0.01$ & $<0.01$ & $<0.01$ & $<0.01$ & $<0.01$ & $<0.01$ & $<0.01$ & $<0.01$ & $<0.01$ & $<0.01$ \\
\hline $\mathrm{K}_{2} \mathrm{O}$ & 0.45 & 0.50 & 0.51 & 0.50 & 0.51 & 0.52 & 0.50 & 0.51 & 0.51 & 0.52 & 0.52 & 0.52 & 0.51 & 0.51 & 0.50 & 0.52 & 0.52 \\
\hline$\overline{\mathrm{MgO}}$ & 1.99 & 1.82 & 1.86 & 1.76 & 1.84 & 1.85 & 1.83 & 1.82 & 1.83 & 1.80 & 1.79 & 1.80 & 1.78 & 1.85 & 1.89 & 1.77 & 1.80 \\
\hline $\mathrm{Na}_{2} \mathrm{O}$ & 20.24 & 19.63 & 19.78 & 20.15 & 20.29 & 19.87 & 20.54 & 19.77 & 19.93 & 19.71 & 19.92 & 19.25 & 20.38 & 20.05 & 19.95 & 19.90 & 19.56 \\
\hline $\mathrm{NiO}$ & $\S$ & 0.08 & 0.06 & 0.05 & 0.04 & 0.04 & 0.03 & 0.03 & 0.02 & 0.01 & 0.01 & 0.01 & 0.00 & 0.00 & 0.00 & 0.00 & 0.00 \\
\hline $\mathrm{P}_{2} \mathrm{O}_{5}$ & $\S$ & 0.11 & 0.09 & 0.08 & 0.08 & 0.06 & 0.07 & 0.06 & 0.06 & 0.06 & 0.07 & 0.04 & 0.05 & 0.04 & 0.05 & 0.04 & 0.04 \\
\hline $\mathrm{SeO}_{2}$ & $\S$ & $<0.01$ & $<0.01$ & $<0.01$ & $<0.01$ & $<0.01$ & $<0.01$ & $<0.01$ & $<0.01$ & $<0.01$ & $<0.01$ & $<0.01$ & $<0.01$ & $<0.01$ & $<0.01$ & $<0.01$ & $<0.01$ \\
\hline $\mathrm{SiO}_{2}$ & 44.22 & 44.97 & 44.86 & 44.94 & 44.88 & 45.51 & 45.36 & 45.51 & 45.41 & 45.71 & 45.21 & 45.83 & 45.10 & 45.61 & 44.84 & 45.30 & 45.62 \\
\hline $\mathrm{SO}_{3}$ & 0.50 & 0.22 & 0.25 & 0.27 & 0.27 & 0.30 & 0.29 & 0.30 & 0.31 & 0.32 & 0.34 & 0.33 & 0.32 & 0.31 & 0.32 & 0.34 & 0.33 \\
\hline $\mathrm{TiO}_{2}$ & 1.99 & 2.14 & 2.16 & 2.11 & 2.10 & 2.09 & 2.04 & 2.13 & 2.12 & 2.12 & 2.13 & 2.14 & 2.10 & 2.06 & 2.16 & 2.15 & 2.15 \\
\hline $\mathrm{V}_{2} \mathrm{O}_{5}$ & $\S$ & 0.01 & 0.01 & 0.01 & 0.01 & $<0.01$ & $<0.01$ & 0.01 & $<0.01$ & 0.01 & 0.01 & 0.01 & 0.01 & 0.01 & $<0.01$ & 0.01 & 0.01 \\
\hline $\mathrm{ZnO}$ & 2.95 & 2.76 & 2.83 & 2.76 & 2.74 & 2.74 & 2.66 & 2.80 & 2.81 & 2.80 & 2.77 & 2.86 & 2.73 & 2.72 & 2.88 & 2.85 & 2.83 \\
\hline $\mathrm{ZrO}_{2}$ & 2.97 & 3.11 & 3.13 & 3.05 & 3.04 & 3.03 & 2.90 & 3.11 & 3.08 & 3.02 & 3.03 & 3.13 & 3.00 & 3.04 & 3.20 & 3.15 & 3.13 \\
\hline Sum & 100.00 & 100.00 & 100.00 & 100.00 & 100.00 & 100.00 & 100.00 & 100.00 & 100.00 & 100.00 & 100.00 & 100.00 & 100.00 & 100.00 & 100.00 & 100.00 & 100.00 \\
\hline
\end{tabular}

$\S$ - Not a target constituent

*Target value

"-" Empty data field 
Table 5.2. XRF Analyzed Composition for DM100 Discharged Glass Samples (wt \%) (continued).

\begin{tabular}{|c|c|c|c|c|c|c|c|c|c|c|c|c|c|c|c|}
\hline- & \multicolumn{6}{|c|}{ Urea and Sugar Test } & \multicolumn{9}{|c|}{ Vanadium Additive Test } \\
\hline Glass (kg) & - & 392.41 & 420.05 & 432.75 & $(360$ & 440kg) & - & 456.85 & 482.05 & 506.15 & 527.65 & 545.65 & 570.85 & 594.15 & 615.39 \\
\hline Constituent & Target & $\begin{array}{l}\text { WVU- } \\
\text { G-88B }\end{array}$ & $\begin{array}{l}\text { WVU- } \\
\text { G-89B }\end{array}$ & $\begin{array}{l}\text { WVU- } \\
\text { G-89C }\end{array}$ & Avg. & \%Dev. & Target & $\begin{array}{l}\text { WVU- } \\
\text { G-130B }\end{array}$ & $\begin{array}{l}\text { WVU- } \\
\text { G-140B }\end{array}$ & \begin{tabular}{|c|} 
WVU- \\
G-141A
\end{tabular} & $\begin{array}{l}\text { WVU- } \\
\text { G-141C }\end{array}$ & \begin{tabular}{|c|} 
WVU- \\
G-146A
\end{tabular} & \begin{tabular}{|c|} 
WVU- \\
G-147A
\end{tabular} & \begin{tabular}{|c|} 
WVU- \\
G-148A
\end{tabular} & $\begin{array}{l}\text { WVU- } \\
\text { G-152A }\end{array}$ \\
\hline $\mathrm{B}_{2} \mathrm{O}_{3} *$ & 8.91 & 8.91 & 8.91 & 8.91 & NC & $\mathrm{NC}$ & 8.91 & 8.91 & 8.91 & 8.91 & 8.91 & 8.91 & 8.91 & 8.91 & 8.91 \\
\hline $\mathrm{CaO}$ & 1.99 & 1.94 & 1.94 & 1.94 & 1.94 & -2.76 & 1.99 & 1.94 & 1.92 & 1.91 & 1.89 & 1.89 & 1.87 & 1.93 & 1.91 \\
\hline $\mathrm{CdO}$ & $\S$ & $<0.01$ & $<0.01$ & $<0.01$ & $<0.01$ & $\mathrm{NC}$ & $\S$ & $<0.01$ & $<0.01$ & $<0.01$ & $<0.01$ & $<0.01$ & $<0.01$ & $<0.01$ & $<0.01$ \\
\hline $\mathrm{Cr}_{2} \mathrm{O}_{3}$ & 0.02 & 0.06 & 0.06 & 0.07 & 0.07 & $\mathrm{NC}$ & 0.02 & 0.08 & 0.08 & 0.09 & 0.09 & 0.10 & 0.10 & 0.11 & 0.11 \\
\hline $\mathrm{Cs}_{2} \mathrm{O}$ & 0.15 & 0.17 & 0.16 & 0.16 & 0.16 & $\mathrm{NC}$ & 0.15 & 0.14 & 0.15 & 0.14 & 0.16 & 0.17 & 0.15 & 0.16 & 0.16 \\
\hline $\mathrm{Fe}_{2} \mathrm{O}_{3}$ & 6.93 & 6.73 & 6.80 & 7.02 & 6.81 & -1.75 & 6.93 & 6.86 & 6.59 & 6.68 & 6.76 & 6.87 & 7.00 & 7.27 & 7.36 \\
\hline I & $\S$ & $<0.01$ & $<0.01$ & $<0.01$ & $<0.01$ & $\mathrm{NC}$ & $\S$ & $<0.01$ & $<0.01$ & $<0.01$ & $<0.01$ & $<0.01$ & $<0.01$ & $<0.01$ & $<0.01$ \\
\hline $\mathrm{K}_{2} \mathrm{O}$ & 0.45 & 0.52 & 0.52 & 0.52 & 0.52 & $\mathrm{NC}$ & 0.45 & 0.51 & 0.50 & 0.54 & 0.54 & 0.53 & 0.52 & 0.50 & 0.49 \\
\hline $\mathrm{MgO}$ & 1.99 & 1.75 & 1.76 & 1.76 & 1.77 & -11.21 & 1.99 & 1.81 & 1.82 & 1.92 & 1.88 & 1.94 & 2.00 & 1.92 & 1.83 \\
\hline $\mathrm{Na} 2 \mathrm{O}$ & 20.24 & 19.83 & 19.74 & 19.29 & 19.60 & -3.14 & 20.24 & 19.52 & 20.14 & 19.75 & 19.59 & 19.38 & 19.06 & 18.31 & 18.64 \\
\hline P2O5 & $\S$ & 0.03 & 0.04 & 0.04 & 0.04 & $\mathrm{NC}$ & $\S$ & 0.02 & 0.03 & 0.03 & 0.03 & 0.02 & $<0.01$ & $<0.01$ & 0.02 \\
\hline $\mathrm{SeO} 2$ & $\S$ & $<0.01$ & $<0.01$ & $<0.01$ & $<0.01$ & $\mathrm{NC}$ & $\S$ & $<0.01$ & $<0.01$ & $<0.01$ & $<0.01$ & $<0.01$ & $<0.01$ & $<0.01$ & $<0.01$ \\
\hline $\mathrm{SiO} 2$ & 44.22 & 45.38 & 45.27 & 45.31 & 45.40 & 2.66 & 44.22 & 45.16 & 45.07 & 45.22 & 45.26 & 45.21 & 45.27 & 45.44 & 45.18 \\
\hline SO3 & 0.50 & 0.33 & 0.33 & 0.32 & 0.33 & $\mathrm{NC}$ & 0.50 & 0.31 & 0.35 & 0.35 & 0.33 & 0.34 & 0.33 & 0.33 & 0.33 \\
\hline $\mathrm{TiO} 2$ & 1.99 & 2.14 & 2.16 & 2.19 & 2.16 & 8.40 & $\S$ & 1.92 & 1.62 & 1.37 & 1.22 & 1.10 & 0.92 & 0.81 & 0.67 \\
\hline V2O5 & $\S$ & 0.01 & $<0.01$ & $<0.01$ & $<0.01$ & $\mathrm{NC}$ & 1.99 & 0.32 & 0.62 & 0.90 & 1.08 & 1.25 & 1.43 & 1.64 & 1.76 \\
\hline $\mathrm{ZnO}$ & 2.95 & 2.85 & 2.86 & 2.97 & 2.88 & -2.45 & 2.95 & 2.91 & 2.76 & 2.79 & 2.83 & 2.86 & 2.96 & 3.10 & 3.14 \\
\hline $\mathrm{ZrO} 2$ & 2.97 & 3.16 & 3.18 & 3.31 & 3.20 & 7.59 & 2.97 & 3.25 & 3.06 & 3.10 & 3.17 & 3.23 & 3.32 & 3.47 & 3.52 \\
\hline Sum & 100.00 & 100.00 & 100.00 & 100.00 & $\mathrm{NC}$ & $\mathrm{NC}$ & 100.00 & 100.00 & 100.00 & 100.00 & 100.00 & 100.00 & 100.00 & 100.00 & 100.00 \\
\hline
\end{tabular}


Table 5.2. XRF Analyzed Composition for DM100 Discharged Glass Samples (wt \%) (continued).

\begin{tabular}{|c|c|c|c|c|c|c|c|c|c|c|c|c|c|c|c|c|c|}
\hline Test & \multicolumn{17}{|c|}{ Vanadium Additive Test } \\
\hline Glass (kg) & - & 615.39 & 638.87 & 661.43 & 683.03 & 703.13 & 714.13 & 737.03 & 783.93 & 802.03 & 826.43 & 848.57 & 872.87 & 900.77 & 930.07 & $(816-$ & $35 \mathrm{~kg})$ \\
\hline Constituent & Target & \begin{tabular}{|c|} 
WVU- \\
G-152A
\end{tabular} & \begin{tabular}{|c|} 
WVU- \\
G-152C
\end{tabular} & \begin{tabular}{|c|} 
WVU- \\
G-153B
\end{tabular} & $\begin{array}{l}\text { WVV- } \\
\text { G-6B }\end{array}$ & \begin{tabular}{|l|} 
WVV- \\
G-6D
\end{tabular} & $\begin{array}{l}\text { WVV- } \\
\text { G-8B }\end{array}$ & $\begin{array}{l}\text { WVV- } \\
\text { G-13A }\end{array}$ & $\begin{array}{l}\text { WVV- } \\
\text { G-14B }\end{array}$ & $\begin{array}{l}\text { WVV- } \\
\text { G-15B }\end{array}$ & $\begin{array}{l}\text { WVV- } \\
\text { G-18B }\end{array}$ & $\begin{array}{l}\text { WVV- } \\
\text { G-19B }\end{array}$ & \begin{tabular}{|l} 
WVV- \\
G-23A
\end{tabular} & $\begin{array}{l}\text { WVV- } \\
\text { G-26A }\end{array}$ & $\begin{array}{l}\text { WVV- } \\
\text { G-29A }\end{array}$ & Avg. & $\%$ Dev \\
\hline $\mathrm{Al}_{2} \mathrm{O}_{3}$ & 6.15 & 5.74 & 5.89 & 5.84 & 6.21 & 6.21 & 6.04 & 6.04 & 5.92 & 6.03 & 6.08 & 6.01 & 5.99 & 5.92 & 6.02 & 6.00 & -2.38 \\
\hline $\mathrm{B}_{2} \mathrm{O}_{3} *$ & 8.91 & 8.91 & 8.91 & 8.91 & 8.91 & 8.91 & 8.91 & 8.91 & 8.91 & 8.91 & 8.91 & 8.91 & 8.91 & 8.91 & 8.91 & $\mathrm{NC}$ & $\mathrm{NC}$ \\
\hline $\mathrm{CaO}$ & 1.99 & 1.91 & 1.88 & 1.88 & 1.90 & 1.88 & 1.86 & 1.86 & 1.89 & 1.86 & 1.89 & 1.89 & 1.91 & 1.88 & 1.90 & 1.90 & -4.65 \\
\hline $\mathrm{CdO}$ & $\S$ & $<0.01$ & $<0.01$ & $<0.01$ & $<0.01$ & $<0.01$ & $<0.01$ & $<0.01$ & $<0.01$ & $<0.01$ & $<0.01$ & $<0.01$ & $<0.01$ & $<0.01$ & $<0.01$ & $<0.01$ & $\mathrm{NC}$ \\
\hline $\mathrm{Cl}$ & 0.56 & 0.23 & 0.23 & 0.25 & 0.27 & 0.27 & 0.28 & 0.27 & 0.27 & 0.27 & 0.27 & 0.27 & 0.27 & 0.28 & 0.25 & 0.27 & $\mathrm{NC}$ \\
\hline $\mathrm{Cr}_{2} \mathrm{O}_{3}$ & 0.02 & 0.11 & 0.12 & 0.12 & 0.12 & 0.12 & 0.12 & 0.12 & 0.13 & 0.13 & 0.13 & 0.14 & 0.13 & 0.14 & 0.16 & 0.14 & $\mathrm{NC}$ \\
\hline $\mathrm{Cs}_{2} \mathrm{O}$ & 0.15 & 0.16 & 0.16 & 0.17 & 0.17 & 0.17 & 0.16 & 0.16 & 0.15 & 0.16 & 0.16 & 0.15 & 0.15 & 0.15 & 0.17 & 0.15 & $\mathrm{NC}$ \\
\hline $\mathrm{Fe}_{2} \mathrm{O}_{3}$ & 6.93 & 7.36 & 7.16 & 7.14 & 6.82 & 6.69 & 6.69 & 6.75 & 6.96 & 6.80 & 6.71 & 6.77 & 6.89 & 6.70 & 7.13 & 6.84 & -1.27 \\
\hline I & $\S$ & $<0.01$ & $<0.01$ & $<0.01$ & $<0.01$ & $<0.01$ & $<0.01$ & $<0.01$ & $<0.01$ & $<0.01$ & $<0.01$ & $<0.01$ & $<0.01$ & $<0.01$ & $<0.01$ & $<0.01$ & $\mathrm{NC}$ \\
\hline $\mathrm{K}_{2} \mathrm{O}$ & 0.45 & 0.49 & 0.51 & 0.51 & 0.51 & 0.53 & 0.50 & 0.52 & 0.52 & 0.51 & 0.49 & 0.49 & 0.49 & 0.48 & 0.48 & 0.49 & $\mathrm{NC}$ \\
\hline $\mathrm{MgO}$ & 1.99 & 1.83 & 1.93 & 1.93 & 1.98 & 2.09 & 2.12 & 2.03 & 2.01 & 2.02 & 2.04 & 1.97 & 1.86 & 1.95 & 1.74 & 1.91 & -3.96 \\
\hline $\mathrm{Na}_{2} \mathrm{O}$ & 20.24 & 18.64 & 18.60 & 18.76 & 19.05 & 19.00 & 19.66 & 19.57 & 18.96 & 19.63 & 19.37 & 19.43 & 19.63 & 19.69 & 18.97 & 19.42 & -4.06 \\
\hline $\mathrm{NiO}$ & $\S$ & $<0.01$ & $<0.01$ & $<0.01$ & $<0.01$ & $<0.01$ & $<0.01$ & $<0.01$ & $<0.01$ & $<0.01$ & $<0.01$ & $<0.01$ & $<0.01$ & $<0.01$ & $<0.01$ & $<0.01$ & $\mathrm{NC}$ \\
\hline $\mathrm{P}_{2} \mathrm{O}_{5}$ & $\S$ & 0.02 & 0.02 & 0.02 & 0.03 & 0.03 & 0.02 & 0.03 & 0.03 & 0.03 & 0.03 & 0.03 & 0.02 & 0.02 & 0.02 & 0.03 & $\mathrm{NC}$ \\
\hline $\mathrm{SeO}_{2}$ & $\S$ & $<0.01$ & $<0.01$ & $<0.01$ & $<0.01$ & $<0.01$ & $<0.01$ & $<0.01$ & $<0.01$ & $<0.01$ & $<0.01$ & $<0.01$ & $<0.01$ & $<0.01$ & $<0.01$ & $<0.01$ & $\mathrm{NC}$ \\
\hline $\mathrm{SiO}_{2}$ & \begin{tabular}{|l|l|}
4422 \\
\end{tabular} & 45.18 & 45.51 & 45.30 & 45.29 & \begin{tabular}{|l|}
45.54 \\
\end{tabular} & 45.14 & 45.16 & 45.42 & 45.00 & \begin{tabular}{|l|}
45.43 \\
\end{tabular} & 45.36 & 44.99 & 45.46 & 45.08 & 45.26 & 2.36 \\
\hline $\mathrm{SO}_{3}$ & 0.50 & 0.33 & 0.34 & 0.34 & 0.38 & 0.40 & 0.39 & 0.38 & 0.38 & 0.39 & 0.39 & 0.39 & 0.39 & 0.40 & 0.37 & 0.39 & $\mathrm{NC}$ \\
\hline $\mathrm{TiO}_{2}$ & $\S$ & 0.67 & 0.58 & 0.49 & 0.42 & 0.35 & 0.38 & 0.30 & 0.23 & 0.20 & 0.18 & 0.16 & 0.15 & 0.13 & 0.12 & 0.15 & $\mathrm{NC}$ \\
\hline $\mathrm{V}_{2} \mathrm{O}_{5}$ & 1.99 & 1.76 & 1.80 & 1.90 & 1.91 & 1.94 & 1.92 & 2.00 & 2.12 & 2.08 & 2.06 & 2.04 & 2.07 & 2.01 & 2.09 & 2.05 & 3.18 \\
\hline $\mathrm{ZnO}$ & 2.95 & 3.14 & 3.01 & 3.03 & 2.85 & 2.79 & 2.76 & 2.79 & 2.90 & 2.84 & 2.81 & 2.85 & 2.93 & 2.83 & 3.14 & 2.91 & -1.33 \\
\hline $\mathrm{ZrO}_{2}$ & 2.97 & 3.52 & 3.33 & 3.40 & 3.17 & 3.08 & 3.05 & 3.12 & 3.20 & 3.13 & 3.05 & 3.13 & 3.21 & 3.04 & 3.45 & 3.18 & 6.99 \\
\hline Sum & 100.00 & 100.00 & 100.00 & 100.00 & 100.00 & 100.00 & 100.00 & 100.00 & 100.00 & 100.00 & 100.00 & 100.00 & 100.00 & 100.00 & 100.00 & $\mathrm{NC}$ & $\mathrm{NC}$ \\
\hline
\end{tabular}


Table 5.2. XRF Analyzed Composition for DM100 Discharged Glass Samples (wt \%) (continued).

\begin{tabular}{|c|c|c|c|c|c|c|c|c|c|c|c|c|c|}
\hline - & \multicolumn{13}{|c|}{ Starch and Sugar Test } \\
\hline Glass (kg) & - & 953.17 & 972.77 & 1000.57 & 1028.97 & 1052.47 & 1078.57 & 1098.77 & 1124.37 & 1157.67 & 1182.95 & 1210.55 & 1236.95 \\
\hline Constituent & Target & $\begin{array}{c}\text { WVV-G- } \\
54 \mathrm{~B}\end{array}$ & $\begin{array}{c}\text { WVV-G- } \\
59 A\end{array}$ & $\begin{array}{c}\text { WVV-G- } \\
60 \mathrm{~A}\end{array}$ & $\begin{array}{c}\text { WVV-G- } \\
61 \mathrm{~A}\end{array}$ & $\begin{array}{c}\text { WVV-G- } \\
65 \mathrm{~B}\end{array}$ & $\begin{array}{c}\text { WVV-G- } \\
66 \mathrm{~B}\end{array}$ & $\begin{array}{c}\text { WVV-G- } \\
67 \mathrm{~B}\end{array}$ & $\begin{array}{c}\text { WVV-G- } \\
\text { 67D }\end{array}$ & $\begin{array}{c}\text { WVV-G- } \\
69 \mathrm{~B}\end{array}$ & $\begin{array}{c}\text { WVV-G- } \\
74 \mathrm{~B}\end{array}$ & $\begin{array}{c}\text { WVV-G- } \\
78 \mathrm{~A}\end{array}$ & $\begin{array}{c}\text { WVV-G- } \\
81 \mathrm{~A}\end{array}$ \\
\hline $\mathrm{Al}_{2} \mathrm{O}_{3}$ & 6.13 & 6.13 & 6.14 & 6.17 & 6.24 & 6.25 & 6.20 & 6.08 & 6.30 & 6.18 & 6.03 & 6.71 & 5.97 \\
\hline $\mathrm{B}_{2} \mathrm{O}_{3} *$ & 8.91 & 8.91 & 8.91 & 8.91 & 8.91 & 8.91 & 8.91 & 8.91 & 8.91 & 8.91 & 8.91 & 8.91 & 8.91 \\
\hline $\mathrm{CaO}$ & 1.97 & 1.91 & 1.92 & 1.88 & 1.83 & 1.87 & 1.85 & 1.87 & 1.85 & 1.84 & 1.80 & 1.80 & 1.86 \\
\hline $\mathrm{CdO}$ & 0.10 & $<0.01$ & 0.05 & 0.06 & 0.07 & 0.08 & 0.08 & 0.09 & 0.08 & 0.09 & 0.08 & 0.09 & 0.08 \\
\hline $\mathrm{Cl}$ & 0.56 & 0.14 & 0.19 & 0.21 & 0.25 & 0.25 & 0.25 & 0.28 & 0.28 & 0.27 & 0.26 & 0.26 & 0.27 \\
\hline $\mathrm{Cr}_{2} \mathrm{O}_{3}$ & 0.02 & 0.14 & 0.13 & 0.12 & 0.10 & 0.10 & 0.10 & 0.09 & 0.09 & 0.08 & 0.07 & 0.07 & 0.07 \\
\hline $\mathrm{Cs}_{2} \mathrm{O}$ & 0.14 & 0.13 & 0.14 & 0.15 & 0.14 & 0.14 & 0.15 & 0.16 & 0.13 & 0.15 & 0.14 & 0.15 & 0.13 \\
\hline $\mathrm{F}$ & 0.02 & NA & NA & NA & NA & NA & NA & NA & NA & NA & NA & NA & NA \\
\hline $\mathrm{Fe}_{2} \mathrm{O}_{3}$ & 6.91 & 6.74 & 6.80 & 6.73 & 6.41 & 6.77 & 6.65 & 6.77 & 6.53 & 6.60 & 6.28 & 6.47 & 6.52 \\
\hline I & 0.10 & 0.01 & 0.02 & 0.04 & 0.04 & 0.04 & 0.04 & 0.05 & 0.04 & 0.05 & 0.04 & 0.05 & 0.04 \\
\hline $\mathrm{K}_{2} \mathrm{O}$ & 0.44 & 0.51 & 0.53 & 0.52 & 0.51 & 0.53 & 0.52 & 0.52 & 0.55 & 0.53 & 0.50 & 0.58 & 0.51 \\
\hline $\mathrm{MgO}$ & 1.97 & 1.87 & 1.87 & 1.90 & 1.84 & 1.86 & 1.84 & 1.86 & 1.87 & 1.87 & 1.86 & 1.86 & 1.93 \\
\hline $\mathrm{Na}_{2} \mathrm{O}$ & 20.07 & 20.21 & 19.44 & 19.54 & 20.43 & 20.07 & 19.82 & 20.23 & 20.09 & 19.96 & 20.59 & 20.21 & 20.14 \\
\hline $\mathrm{NiO}$ & $<0.01$ & 0.03 & 0.03 & 0.02 & 0.01 & 0.01 & 0.01 & 0.01 & $<0.01$ & $<0.01$ & $<0.01$ & $<0.01$ & $<0.01$ \\
\hline $\mathrm{P}_{2} \mathrm{O}_{5}$ & 0.07 & 0.06 & 0.07 & 0.08 & 0.07 & 0.08 & 0.07 & 0.08 & 0.09 & 0.09 & 0.09 & 0.09 & 0.10 \\
\hline $\mathrm{SeO}_{2}$ & 0.10 & 0.01 & 0.02 & 0.02 & 0.02 & 0.03 & 0.03 & 0.03 & 0.03 & 0.02 & 0.02 & 0.02 & 0.02 \\
\hline $\mathrm{SiO}_{2}$ & 44.13 & 44.94 & 45.45 & 45.42 & 45.40 & 44.85 & 45.42 & 44.79 & 45.35 & 45.39 & 45.82 & 44.98 & 45.64 \\
\hline $\mathrm{SO}_{3}$ & 0.5 & 0.36 & 0.37 & 0.38 & 0.37 & 0.36 & 0.35 & 0.36 & 0.36 & 0.36 & 0.35 & 0.33 & 0.34 \\
\hline $\mathrm{TiO}_{2}$ & 1.97 & 1.60 & 1.64 & 1.68 & 1.67 & 1.77 & 1.74 & 1.83 & 1.82 & 1.84 & 1.81 & 1.84 & 1.89 \\
\hline $\mathrm{V}_{2} \mathrm{O}_{5}$ & $\S$ & 0.48 & 0.43 & 0.37 & 0.29 & 0.25 & 0.27 & 0.19 & 0.16 & 0.13 & 0.10 & 0.08 & 0.08 \\
\hline $\mathrm{ZnO}$ & 2.94 & 2.76 & 2.77 & 2.76 & 2.59 & 2.74 & 2.69 & 2.75 & 2.63 & 2.68 & 2.50 & 2.60 & 2.63 \\
\hline $\mathrm{ZrO}_{2}$ & 2.96 & 3.06 & 3.09 & 3.04 & 2.83 & 3.04 & 3.00 & 3.04 & 2.85 & 2.96 & 2.73 & 2.90 & 2.87 \\
\hline Sum & 100.00 & 100.00 & 100.00 & 100.00 & 100.00 & 100.00 & 100.00 & 100.00 & 100.00 & 100.00 & 100.00 & 100.00 & 100.00 \\
\hline
\end{tabular}


The Catholic University of America Vitreous State Laboratory
Glass Formulation Testing to Increase Sulfate Volatilization

Final Report, VSL-04R4970-1, Rev. 0

Table 5.2. XRF Analyzed Composition for DM100 Discharged Glass Samples (wt\%) (continued).

\begin{tabular}{|c|c|c|c|c|c|c|c|}
\hline \multirow{3}{*}{$\begin{array}{c}- \\
\text { Glass (kg) } \\
\text { Element }\end{array}$} & \multicolumn{7}{|c|}{ Starch and Sugar Test } \\
\hline & \multirow{2}{*}{$\frac{-}{\text { Target }}$} & \multirow{2}{*}{\begin{tabular}{|c|}
1282.55 \\
WVV-G-82C
\end{tabular}} & \multirow{2}{*}{\begin{tabular}{|c|}
1304.35 \\
WVV-G-86B \\
\end{tabular}} & \multirow{2}{*}{\begin{tabular}{|c|}
1332.63 \\
WVV-G-87A \\
\end{tabular}} & \multirow{2}{*}{\begin{tabular}{|c|}
1348.33 \\
WVV-G-87B \\
\end{tabular}} & \multicolumn{2}{|c|}{$(1305-1350 \mathrm{~kg})$} \\
\hline & & & & & & Avg. & \%dev \\
\hline $\mathrm{Al}_{2} \mathrm{O}_{3}$ & 6.13 & 6.39 & 6.19 & 6.14 & 6.18 & 6.16 & 0.49 \\
\hline $\mathrm{B}_{2} \mathrm{O}_{3} *$ & 8.91 & 8.91 & 8.91 & 8.91 & 8.91 & $\mathrm{NC}$ & $\mathrm{NC}$ \\
\hline $\mathrm{CaO}$ & 1.97 & 1.85 & 1.84 & 1.87 & 1.83 & 1.85 & -6.29 \\
\hline $\mathrm{CdO}$ & 0.10 & 0.09 & 0.09 & 0.09 & 0.09 & 0.09 & $\mathrm{NC}$ \\
\hline $\mathrm{Cl}$ & 0.56 & 0.27 & 0.27 & 0.27 & 0.29 & 0.28 & NC \\
\hline $\mathrm{Cr}_{2} \mathrm{O}_{3}$ & 0.02 & 0.06 & 0.06 & 0.07 & 0.06 & 0.07 & NC \\
\hline $\mathrm{Cs}_{2} \mathrm{O}$ & 0.14 & 0.15 & 0.16 & 0.14 & 0.15 & 0.15 & $\mathrm{NC}$ \\
\hline $\mathrm{F}$ & 0.02 & NA & NA & NA & NA & $\mathrm{NC}$ & NC \\
\hline $\mathrm{Fe}_{2} \mathrm{O}_{3}$ & 6.91 & 6.82 & 6.62 & 6.75 & 6.70 & 6.72 & -2.70 \\
\hline $\mathrm{I}$ & 0.10 & 0.05 & 0.04 & 0.04 & 0.04 & 0.04 & $\mathrm{NC}$ \\
\hline $\mathrm{K}_{2} \mathrm{O}$ & 0.44 & 0.53 & 0.54 & 0.54 & 0.54 & 0.54 & $\mathrm{NC}$ \\
\hline $\mathrm{MgO}$ & 1.97 & 1.86 & 1.93 & 1.91 & 1.93 & 1.92 & -2.65 \\
\hline $\mathrm{Na}_{2} \mathrm{O}$ & 20.07 & 19.62 & 19.64 & 19.64 & 19.86 & 19.75 & -1.60 \\
\hline $\mathrm{NiO}$ & $<0.01$ & $<0.01$ & $<0.01$ & $<0.01$ & $<0.01$ & $<0.01$ & $\mathrm{NC}$ \\
\hline $\mathrm{P}_{2} \mathrm{O}_{5}$ & 0.07 & 0.09 & 0.10 & 0.10 & 0.10 & 0.10 & NC \\
\hline $\mathrm{SeO}_{2}$ & 0.10 & 0.02 & 0.02 & 0.02 & 0.02 & 0.02 & NC \\
\hline $\mathrm{SiO}_{2}$ & 44.13 & 45.11 & 45.68 & 45.41 & 45.28 & 45.35 & 2.76 \\
\hline $\mathrm{SO}_{3}$ & 0.50 & 0.32 & 0.36 & 0.35 & 0.35 & 0.35 & $\mathrm{NC}$ \\
\hline $\mathrm{TiO}_{2}$ & 1.97 & 1.92 & 1.90 & 1.93 & 1.93 & 1.93 & -1.84 \\
\hline $\mathrm{V}_{2} \mathrm{O}_{5}$ & $\S$ & 0.06 & 0.05 & 0.05 & 0.04 & 0.04 & NC \\
\hline $\mathrm{ZnO}$ & 2.94 & 2.76 & 2.65 & 2.71 & 2.69 & 2.70 & -8.23 \\
\hline $\mathrm{ZrO}_{2}$ & 2.96 & 3.12 & 2.95 & 3.05 & 3.00 & 3.03 & 2.31 \\
\hline Sum & 100.00 & 100.00 & 100.00 & 100.00 & 100.00 & $\mathrm{NC}$ & $\mathrm{NC}$ \\
\hline $\begin{array}{l}\text { S- Not a targ } \\
\text { *Target value } \\
\text { '-" Empty da } \\
\text { NA - Not an } \\
\text { NC - Not cal }\end{array}$ & onstituent & & & & & & \\
\hline
\end{tabular}


The Catholic University of America Vitreous State Laboratory
Glass Formulation Testing to Increase Sulfate Volatilization

Final Report, VSL-04R4970-1, Rev. 0

Table 5.3. Comparison of XRF and DCP Analysis of Melter Glass Samples (wt\%).

\begin{tabular}{|c|c|c|c|c|c|c|}
\hline \multirow{3}{*}{ - } & \multicolumn{3}{|c|}{ Urea and Sugar Test } & \multicolumn{3}{|c|}{ Vanadium Additive Test } \\
\hline & \multirow{2}{*}{ Target } & \multicolumn{2}{|c|}{ WVU-G-89C } & \multirow{2}{*}{ Target } & \multicolumn{2}{|c|}{ WVV-G-26A } \\
\hline & & XRF & DCP & & XRF & DCP \\
\hline $\mathrm{Al}_{2} \mathrm{O}_{3}$ & 6.15 & 5.91 & 5.87 & 6.15 & 5.92 & 6.09 \\
\hline $\mathrm{B}_{2} \mathrm{O}_{3}$ & 8.91 & 8.91* & 8.98 & 8.91 & 8.91* & 9.13 \\
\hline $\mathrm{CaO}$ & 1.99 & 1.94 & 1.81 & 1.99 & 1.88 & 1.86 \\
\hline $\mathrm{Cl}$ & 0.56 & 0.28 & NA & 0.56 & 0.28 & NA \\
\hline $\mathrm{Cr}_{2} \mathrm{O}_{3}$ & 0.02 & 0.07 & 0.06 & 0.02 & 0.14 & 0.13 \\
\hline $\mathrm{Cs}_{2} \mathrm{O}$ & 0.15 & 0.16 & NA & 0.15 & 0.15 & NA \\
\hline $\mathrm{Fe}_{2} \mathrm{O}_{3}$ & 6.93 & 7.02 & 6.47 & 6.93 & 6.70 & 6.71 \\
\hline $\mathrm{K}_{2} \mathrm{O}$ & 0.45 & 0.52 & 0.55 & 0.45 & 0.48 & 0.54 \\
\hline $\mathrm{MgO}$ & 1.99 & 1.76 & 1.80 & 1.99 & 1.95 & 1.94 \\
\hline $\mathrm{Na}_{2} \mathrm{O}$ & 20.24 & 19.29 & 18.25 & 20.24 & 19.69 & 18.59 \\
\hline $\mathrm{NiO}$ & $\S$ & $<0.01$ & 0.02 & $\S$ & $<0.01$ & 0.03 \\
\hline $\mathrm{P}_{2} \mathrm{O}_{5}$ & $\S$ & 0.04 & 0.04 & $\S$ & 0.02 & $<0.01$ \\
\hline $\mathrm{SiO}_{2}$ & 44.22 & 45.31 & 44.35 & 44.22 & 45.46 & 45.18 \\
\hline $\mathrm{SO}_{3}{ }^{\#}$ & 0.5 & 0.32 & 0.11 & 0.50 & 0.40 & 0.50 \\
\hline $\mathrm{TiO}_{2}$ & 1.99 & 2.19 & 2.16 & $\S$ & 0.13 & 0.16 \\
\hline $\mathrm{V}_{2} \mathrm{O}_{5}$ & $\S$ & $<0.01$ & 0.01 & 1.99 & 2.01 & 1.86 \\
\hline $\mathrm{ZnO}$ & 2.95 & 2.97 & 2.81 & 2.95 & 2.83 & 2.90 \\
\hline $\mathrm{ZrO}_{2}$ & 2.97 & 3.31 & 2.83 & 2.97 & 3.04 & 2.88 \\
\hline Sum & 100.00 & 100.00 & 96.11 & 100.00 & 100.00 & 98.50 \\
\hline
\end{tabular}

* Target values

\# $\mathrm{SO}_{3}$ measured by IC

"-" Empty data cell

$\S$ - Not a target constituent

NA - Not analyzed 
The Catholic University of America Vitreous State Laboratory
Glass Formulation Testing to Increase Sulfate Volatilization

Final Report, VSL-04R4970-1, Rev. 0

Table 5.4. XRF Analyzed Glass Compositions for DM100 Dip Samples (wt\%).

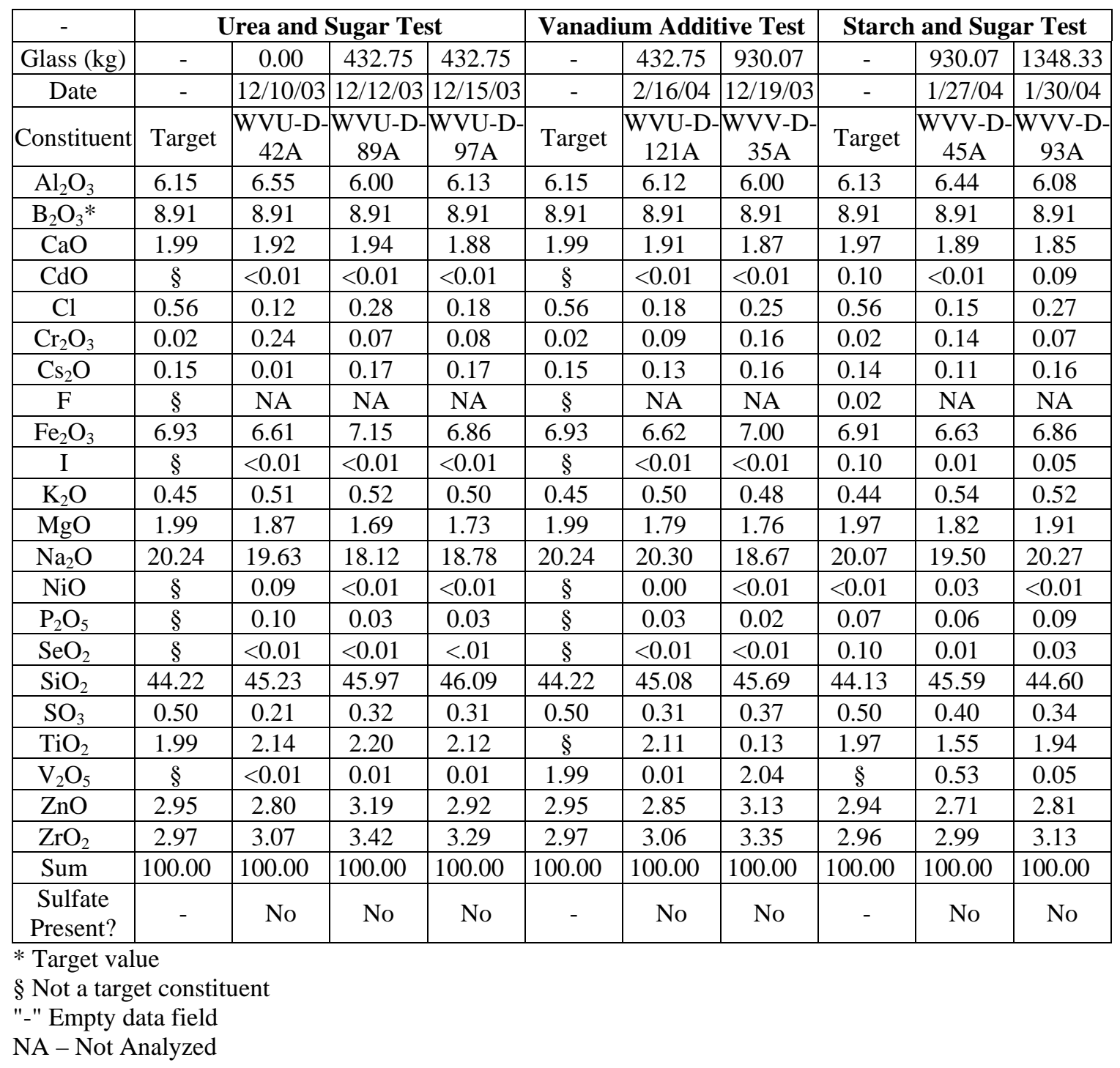


The Catholic University of America Vitreous State Laboratory
Glass Formulation Testing to Increase Sulfate Volatilization Final Report, VSL-04R4970-1, Rev. 0

Table 5.5. Glass Redox for Selected Glass Samples.

\begin{tabular}{|c|c|c|c|c|}
\hline- & Sampling Date & $\begin{array}{c}\text { Cumulative } \\
\text { Glass (kg) }\end{array}$ & Sample Name & $\begin{array}{c}\text { \%Fe }{ }^{2+} \\
/ \text { Total Fe }\end{array}$ \\
\hline \multirow{3}{*}{$\begin{array}{c}\text { Urea and } \\
\text { Sugar Test }\end{array}$} & $12 / 11 / 03$ & 111.44 & WVU-G-64B & 18 \\
\hline & \multirow{2}{*}{$12 / 12 / 03$} & 333.96 & WVU-G-84A & 25 \\
\hline & & 420.05 & WVU-G-89B & 25 \\
\hline \multirow{4}{*}{$\begin{array}{c}\text { Vanadium } \\
\text { Additive Test }\end{array}$} & \multirow{2}{*}{$12 / 16 / 03$} & 456.85 & WVU-G-130B & 5 \\
\hline & & 506.15 & WVU-G-141A & 2 \\
\hline & \multirow{2}{*}{$12 / 18 / 03$} & 683.08 & WVV-G-6B & 1 \\
\hline & & 848.57 & WVV-G-19B & 3 \\
\hline \multirow{6}{*}{$\begin{array}{l}\text { Starch and } \\
\text { Sugar Test }\end{array}$} & \multirow{2}{*}{$1 / 28 / 04$} & 972.77 & WVV-G-59A & 28 \\
\hline & & 1028.97 & WVV-G-61A & 22 \\
\hline & \multirow{3}{*}{ 01/29/04 } & 1052.47 & WVV-G-65B & 20 \\
\hline & & 1078.57 & WVV-G-66B & 29 \\
\hline & & 1182.95 & WVV-G-74B & 18 \\
\hline & $1 / 30 / 04$ & 1262.35 & WVV-G-82A & 24 \\
\hline
\end{tabular}


Table 6.1. Results from Melter Off-Gas Emission Samples.

\begin{tabular}{|c|c|c|c|c|c|c|c|c|c|}
\hline \multirow{2}{*}{\multicolumn{2}{|c|}{$\begin{array}{c}- \\
\text { Sampling } \\
\text { Interval }\end{array}$}} & \multicolumn{4}{|c|}{ Urea and Sugar Test } & \multicolumn{4}{|c|}{ Vanadium Additive Test } \\
\hline & & & $\begin{array}{r}12 / 12 / 0310 \\
95.2 \% \mathrm{Is} \\
\end{array}$ & $\begin{array}{l}25-11: 25 \text {, } \\
\text { kinetic }\end{array}$ & & & $\begin{array}{r}2 / 18 / 0317: \\
100.7 \% \text { Is } \\
\end{array}$ & $\begin{array}{l}9-18: 49 \\
\text { kinetic }\end{array}$ & \\
\hline \multicolumn{2}{|c|}{ Moisture } & \multicolumn{4}{|c|}{$9.9 \%$} & \multicolumn{4}{|c|}{$17.3 \%$} \\
\hline & - & $\begin{array}{c}\text { Feed } \\
\text { Rate } \\
(\mathrm{mg} / \mathrm{min})\end{array}$ & $\begin{array}{c}\text { Emissions } \\
\text { Rate } \\
\text { (mg/min) }\end{array}$ & $\%$ of Feed & DF & $\begin{array}{c}\text { Feed } \\
\text { Rate } \\
(\mathrm{mg} / \mathrm{min})\end{array}$ & $\begin{array}{c}\text { Emissions } \\
\text { Rate } \\
\text { (mg/min) }\end{array}$ & $\%$ of Feed & DF \\
\hline \multirow{19}{*}{ 营 } & Total $^{\$}$ & 173600 & 1400 & 0.81 & 124 & 158300 & 1067 & 0.67 & 148 \\
\hline & $\mathrm{Al}$ & 4736 & 19.71 & 0.42 & 240 & 4317 & 9.50 & 0.22 & 454 \\
\hline & $\mathrm{B}$ & 4025 & 37.57 & 0.93 & 107 & 3669 & 19.75 & 0.54 & 186 \\
\hline & $\mathrm{Ca}$ & 2071 & 6.43 & 0.31 & 322 & 1888 & 2.94 & 0.16 & 643 \\
\hline & $\mathrm{Cl}^{*}$ & 815 & 342.60 & 42.04 & 2.4 & 743 & 410.08 & 55.19 & 1.8 \\
\hline & $\mathrm{Cr}$ & 20 & 0.58 & 2.93 & 34.1 & 18 & 2.07 & 11.41 & 8.8 \\
\hline & Cs & 206 & 45.82 & 22.25 & 4.5 & 188 & 40.55 & 21.60 & 4.6 \\
\hline & $\mathrm{F}^{*}$ & 0 & 6.02 & NC & NC & 0 & 4.80 & $\mathrm{NC}$ & NC \\
\hline & $\mathrm{Fe}$ & 7054 & 12.53 & 0.18 & 563 & 6430 & 5.12 & 0.08 & 1255 \\
\hline & $\mathrm{K}$ & 544 & 28.85 & 5.31 & 18.8 & 496 & 24.64 & 4.97 & 20.1 \\
\hline & $\mathrm{Mg}$ & 1747 & 0.59 & 0.03 & 2970 & 1592 & 0.26 & 0.02 & 6189 \\
\hline & $\mathrm{Na}$ & 21859 & 324.23 & 1.48 & 67.4 & 19927 & 274.84 & 1.38 & 72.5 \\
\hline & $\mathrm{P}$ & 0 & 0.33 & $\mathrm{NC}$ & NC & 0 & 0.30 & NC & NC \\
\hline & $\mathrm{S}^{*}$ & 292 & 46.82 & 16.03 & 6.24 & 266 & 37.91 & 14.25 & 7.02 \\
\hline & $\mathrm{Si}$ & 30091 & 57.69 & 0.19 & 522 & 27431 & 20.92 & 0.08 & 1311 \\
\hline & $\mathrm{Ti}$ & 1737 & 8.78 & 0.51 & 198 & 0 & $<0.10$ & $\mathrm{NC}$ & NC \\
\hline & $\mathrm{V}$ & 0 & NA & NA & NA & 1479 & 8.32 & 0.56 & 178 \\
\hline & $\mathrm{Zn}$ & 3450 & 17.69 & 0.51 & 195 & 3145 & 8.88 & 0.28 & 354 \\
\hline & $\mathrm{Zr}$ & 3201 & 2.23 & 0.07 & 1436 & 2918 & 1.01 & 0.03 & 2879 \\
\hline \multirow{4}{*}{ జ్ } & B & 4025 & 14.87 & 0.37 & 271 & 3669 & 15.41 & 0.42 & 238 \\
\hline & $\mathrm{Cl}$ & 815 & $<0.10$ & $<0.01$ & $>8150$ & 743 & 0.50 & 0.07 & 1482 \\
\hline & $\mathrm{F}$ & 0 & $<0.10$ & $\mathrm{NC}$ & NC & 0 & $<0.10$ & $\mathrm{NC}$ & $\mathrm{NC}$ \\
\hline & $\mathrm{S}$ & 292 & 22.03 & 7.55 & 13.2 & 266 & 0.97 & 0.36 & 275 \\
\hline
\end{tabular}

$\$$ - From gravimetric analysis of filters and front-half nitric acid analytical results

NA - Not Analyzed

NC - Not Calculated

* - From water dissolution of filter particulate

"-" Empty data field 
The Catholic University of America Vitreous State Laboratory
Glass Formulation Testing to Increase Sulfate Volatilization

Final Report, VSL-04R4970-1, Rev. 0

Table 6.1. Results from Melter Off-Gas Emission Samples (continued).

\begin{tabular}{|c|c|c|c|c|c|}
\hline \multirow{2}{*}{\multicolumn{2}{|c|}{$\begin{array}{c}\text { - } \\
\text { Sampling } \\
\text { Interval }\end{array}$}} & \multicolumn{4}{|c|}{ Starch and Sugar Test } \\
\hline & & \multicolumn{4}{|c|}{$\begin{array}{c}\text { 01/29/04 16:51 - 17:51, } \\
\text { 98.9\% Isokinetic }\end{array}$} \\
\hline \multicolumn{2}{|c|}{ Moisture } & \multicolumn{4}{|c|}{$10.2 \%$} \\
\hline & - & $\begin{array}{l}\text { Feed Rate } \\
(\mathrm{mg} / \mathrm{min})\end{array}$ & $\begin{array}{c}\text { Emissions } \\
\text { Rate } \\
(\mathrm{mg} / \mathrm{min})\end{array}$ & $\begin{array}{l}\% \text { of } \\
\text { Feed }\end{array}$ & $\mathrm{DF}$ \\
\hline \multirow{21}{*}{ 莺 } & Total $^{\$}$ & 182900 & 3511 & 1.92 & 52.1 \\
\hline & $\mathrm{Al}$ & 4914 & 48.41 & 0.99 & 102 \\
\hline & $\mathrm{B}$ & 4190 & 40.68 & 0.97 & 103 \\
\hline & $\mathrm{Ca}$ & 2134 & 22.74 & 1.07 & 93.9 \\
\hline & $\mathrm{Cd}$ & 136 & 40.80 & 30.07 & 3.3 \\
\hline & $\mathrm{Cl}^{*}$ & 849 & 401.07 & 47.24 & 2.12 \\
\hline & $\mathrm{Cr}$ & 21 & 1.01 & 4.86 & 20.6 \\
\hline & Cs & 200 & 47.03 & 23.50 & 4.3 \\
\hline & $\mathrm{F}^{*}$ & 30 & 71.29 & 238 & $\mathrm{NC}$ \\
\hline & $\mathrm{Fe}$ & 7322 & 112.96 & 1.54 & 64.8 \\
\hline & $\mathrm{I}^{*}$ & 152 & 25.54 & 16.80 & 6.0 \\
\hline & $\mathrm{K}$ & 553 & 39.79 & 7.19 & 13.9 \\
\hline & $\mathrm{Mg}$ & 1800 & 1.16 & 0.06 & 1549 \\
\hline & $\mathrm{Na}$ & 22564 & 598.47 & 2.65 & 37.7 \\
\hline & $\mathrm{P}$ & 46 & 2.02 & 4.36 & 22.9 \\
\hline & $\mathrm{S}^{*}$ & 304 & 92.67 & 30.48 & 3.28 \\
\hline & Se & 108 & 69.82 & 64.75 & 1.5 \\
\hline & Si & 31260 & 179.45 & 0.57 & 174 \\
\hline & $\mathrm{Ti}$ & 1790 & 42.61 & 2.38 & 42.0 \\
\hline & $\mathrm{Zn}$ & 3579 & 76.05 & 2.12 & 47.1 \\
\hline & $\mathrm{Zr}$ & 3321 & 7.01 & 0.21 & 473 \\
\hline \multirow{6}{*}{ త్రి } & $\mathrm{B}$ & 4190 & 4.53 & 0.11 & 925 \\
\hline & $\mathrm{Cl}$ & 849 & $<0.10$ & $<0.01$ & $>8490$ \\
\hline & $\mathrm{F}$ & 30 & $<0.10$ & $<0.01$ & $>300$ \\
\hline & $\mathrm{I}$ & 152 & 40.64 & 26.74 & 3.74 \\
\hline & $\mathrm{S}$ & 304 & 41.13 & 13.55 & 7.4 \\
\hline & $\mathrm{Se}$ & 108 & $<1.00$ & $<1.00$ & $>108$ \\
\hline
\end{tabular}

$\$$ - From gravimetric analysis of filters and front-half nitric acid analytical results

NA - Not Analyzed

NC - Not Calculated

* - From water dissolution of filter particulate

"-" Empty data field 
The Catholic University of America Vitreous State Laboratory
Glass Formulation Testing to Increase Sulfate Volatilization Final Report, VSL-04R4970-1, Rev. 0

Table 6.2. Average Concentration (ppmv) of Selected Species in Off-Gas Measured by FTIR Spectroscopy during DM100 Tests.

\begin{tabular}{|c|c|c|c|}
\hline \multirow[t]{2}{*}{ - } & Urea and Sugar Test & $\begin{array}{c}\text { Vanadium Additive } \\
\text { Test }\end{array}$ & Starch and Sugar Test \\
\hline & $12 / 10 / 03-12 / 12 / 03$ & $12 / 16 / 03-12 / 19 / 03$ & $01 / 28 / 04-01 / 30 / 04$ \\
\hline $\mathrm{N}_{2} \mathrm{O}$ & 79 & 110 & 120 \\
\hline NO & 300 & 1100 & 560 \\
\hline $\mathrm{NO}_{2}$ & 7.0 & 110 & 16 \\
\hline $\mathrm{NH}_{3}$ & 1700 & 68 & 190 \\
\hline $\mathrm{H}_{2} \mathrm{O} \%$ & 4.7 & 4.9 & 4.2 \\
\hline $\mathrm{CO}_{2}$ & 3300 & 2100 & 3000 \\
\hline $\mathrm{HNO}_{2}$ & $<1.0$ & $<1.0$ & $<1.0$ \\
\hline $\mathrm{HNO}_{3}$ & $<1.0$ & $<1.0$ & $<1.0$ \\
\hline HCN & $<1.0$ & $<1.0$ & $<1.0$ \\
\hline $\mathrm{SO}_{2}$ & $<1.0$ & 1.2 & $<1.0$ \\
\hline Acetonitrile & $<1.0$ & $<1.0$ & 13 \\
\hline Acrylonitrile & $<1.0$ & $<1.0$ & $<1.0$ \\
\hline CO & 41 & 32 & 72 \\
\hline HCl & $<1.0$ & $<1.0$ & $<1.0$ \\
\hline HF & $<1.0$ & $<1.0$ & $<1.0$ \\
\hline $\mathbf{H}_{2}{ }^{*}$ & 24 & 46 & 17 \\
\hline
\end{tabular}

* Value determined by gas chromatography

"-" Empty data field 
The Catholic University of America Vitreous State Laboratory
Glass Formulation Testing to Increase Sulfate Volatilization Final Report, VSL-04R4970-1, Rev. 0

Table 6.3. Concentration Ranges (ppmv) of Selected Species in Off-Gas Measured by FTIR Spectroscopy during DM100 Tests.

\begin{tabular}{|c|c|c|c|}
\hline \multirow{2}{*}{ - } & Urea and Sugar Test & Vanadium Additive Test & Starch and Sugar Test \\
\hline & $12 / 10 / 03-12 / 12 / 03$ & $12 / 16 / 03-12 / 19 / 03$ & $01 / 28 / 04-01 / 30 / 04$ \\
\hline $\mathrm{N}_{2} \mathrm{O}$ & $<1.0-260$ & $<1.0-400$ & $10-240$ \\
\hline NO & $13-1100$ & $17-3000$ & $56-1100$ \\
\hline $\mathrm{NO}_{2}$ & $<1.0-98$ & $<1.0-560$ & $<1.0-46$ \\
\hline $\mathrm{NH}_{3}$ & $52-4000$ & $2.8-340$ & $9.2-450$ \\
\hline $\mathrm{H}_{2} \mathrm{O} \%$ & $0.8-9.0$ & $0.4-10$ & $0.7-7.5$ \\
\hline $\mathrm{CO}_{2}$ & $500-8500$ & $400-6200$ & $800-5100$ \\
\hline $\mathrm{HNO}_{2}$ & $<1.0$ & $<1.0-2.9$ & $<1.0$ \\
\hline $\mathrm{HNO}_{3}$ & $<1.0$ & $<1.0$ & $<1.0$ \\
\hline HCN & $<1.0-2.1$ & $<1.0$ & $<1.0$ \\
\hline $\mathrm{SO}_{2}$ & $<1.0-7.0$ & $<1.0-7.0$ & $<1.0$ \\
\hline Acetonitrile & $<1.0$ & $<1.0$ & $<1.0-38$ \\
\hline Acrylonitrile & $<1.0$ & $<1.0$ & $<1.0$ \\
\hline CO & $<1.0-110$ & $<1.0-120$ & $<1.0-150$ \\
\hline $\mathrm{HCl}$ & $<1.0$ & $<1.0$ & $<1.0$ \\
\hline HF & $<1.0$ & $<1.0$ & $<1.0$ \\
\hline
\end{tabular}

"-" Empty data cell 
The Catholic University of America Vitreous State Laboratory
Glass Formulation Testing to Increase Sulfate Volatilization Final Report, VSL-04R4970-1, Rev. 0

Table 6.4. Average NOx Fluxes in Off-Gas Measured by FTIR Spectroscopy.

\begin{tabular}{|c|c|c|c|c|c|}
\hline \multirow{2}{*}{-} & \multirow{2}{*}{$\begin{array}{c}\text { Feed } \\
{[\mathrm{mol} / \mathrm{hr}]}\end{array}$} & \multicolumn{3}{|c|}{ Emissions [mol/h] } & \multirow{2}{*}{$\begin{array}{c}\text { \% Feed } \mathrm{NO}_{\mathrm{x}} \text { Emitted as } \\
\text { Nitrogen Oxides }\end{array}$} \\
\hline & & $\begin{array}{c}\mathrm{N}_{2} \mathrm{O} \\
{[\mathrm{mol} / \mathrm{hr}]}\end{array}$ & $\begin{array}{c}\mathrm{NO} \\
{[\mathrm{mol} / \mathrm{hr}]}\end{array}$ & $\begin{array}{c}\mathrm{NO}_{2} \\
{[\mathrm{~mol} / \mathrm{hr}]}\end{array}$ & \\
\hline $\begin{array}{c}\text { Urea and Sugar } \\
\text { Test }\end{array}$ & 26.2 & 1.0 & 4.8 & 0.1 & 22.5 \\
\hline $\begin{array}{c}\text { Vanadium } \\
\text { Additive Test }\end{array}$ & 27.6 & 1.3 & 12.8 & 1.3 & 55.8 \\
\hline $\begin{array}{c}\text { Starch and Sugar } \\
\text { Test }\end{array}$ & 26.6 & 1.5 & 7.2 & 0.2 & 33.5 \\
\hline
\end{tabular}

"-" Empty data field 
The Catholic University of America Vitreous State Laboratory
Glass Formulation Testing to Increase Sulfate Volatilization

Final Report, VSL-04R4970-1, Rev. 0

Table 6.5. Mass Balance for Sulfur, Iodine, and Selenium During DM100 Tests with LAW Sub-Envelope A1 Simulants (\% of Feed).

\begin{tabular}{|c|c|c|c|c|c|c|}
\hline Test & $\begin{array}{c}\text { Stoichiometric } \\
\text { Ratio }\end{array}$ & Element & Glass & $\begin{array}{c}\text { Particle } \\
\text { Emissions }\end{array}$ & $\begin{array}{c}\text { Gaseous } \\
\text { Emissions }\end{array}$ & Total \\
\hline \multirow{2}{*}{$\begin{array}{c}\text { Urea and Sugar } \\
\text { Test }\end{array}$} & \multirow{2}{*}{$\begin{array}{c}0.5 \text { Urea }+ \\
0.5 \text { Sugar }\end{array}$} & Chlorine & 51 & 42 & $<0.1$ & 93 \\
\hline & & Sulfur & 66 & 16 & 7.55 & 90 \\
\hline \multirow{2}{*}{$\begin{array}{c}\text { Vanadium } \\
\text { Additive Test }\end{array}$} & \multirow{2}{*}{ 0.5 Sugar } & Chlorine & 47 & 55 & $<0.1$ & 102 \\
\hline & & Sulfur & 78 & 14 & 0.4 & 92 \\
\hline \multirow{4}{*}{$\begin{array}{c}\text { Starch and Sugar } \\
\text { Test }\end{array}$} & \multirow{4}{*}{$\begin{array}{l}\text { 0.5 Starch + } \\
0.25 \text { Sugar }\end{array}$} & Chlorine & 50 & 47 & $<0.1$ & 97 \\
\hline & & Sulfur & 70 & 30 & 13.6 & 114 \\
\hline & & Iodine & 40 & 17 & 27 & 84 \\
\hline & & Selenium & 20 & 65 & $<0.1$ & 85 \\
\hline \multirow{2}{*}{$\begin{array}{c}@ 1175^{\circ} \mathrm{C} \\
\left(\mathrm{SO}_{3}=0.23 \mathrm{wt} \%\right) \\
{[31]}\end{array}$} & \multirow{2}{*}{0.5 Sugar } & Chlorine & 75 & 42 & $<0.1$ & 117 \\
\hline & & Sulfur & 91 & 9.2 & 0.4 & 101 \\
\hline \multirow{2}{*}{$\begin{array}{c}\text { @ } 1225^{\circ} \mathrm{C} \\
\left(\mathrm{SO}_{3}=0.23 \mathrm{wt} \%\right) \\
{[31]}\end{array}$} & \multirow{2}{*}{ 0.5 Sugar } & Chlorine & 66 & 61 & $<0.1$ & 127 \\
\hline & & Sulfur & 81 & 19 & 0.6 & 100 \\
\hline \multirow{2}{*}{$\begin{array}{c}+15 \% \text { Simulant } \\
\left(\mathrm{SO}_{3}=0.26 \mathrm{wt} \%\right) \\
{[7]}\end{array}$} & \multirow{2}{*}{ 0.44 Sugar } & Chlorine & 53 & 83 & 1.0 & 137 \\
\hline & & Sulfur & 96 & 12 & $<0.1$ & 108 \\
\hline \multirow{2}{*}{$\begin{array}{c}-15 \% \text { Simulant } \\
\left(\mathrm{SO}_{3}=0.22 \mathrm{wt} \%\right) \\
{[7]}\end{array}$} & \multirow{2}{*}{ 0.57 Sugar } & Chlorine & 63 & 30 & 0.1 & 93 \\
\hline & & Sulfur & 86 & 16 & 0.1 & 102 \\
\hline \multirow{3}{*}{$\begin{array}{c}\left(\mathrm{SO}_{3}=0.19 \mathrm{wt} \%\right) \\
{[27]}\end{array}$} & \multirow{3}{*}{0.5 Sugar } & Chlorine & 56 & 43 & 0.1 & 99 \\
\hline & & Sulfur & 95 & 14 & $<0.1$ & 109 \\
\hline & & Iodine & 20 & $<0.1$ & 73 & 93 \\
\hline
\end{tabular}

"-" Empty data field 
The Catholic University of America Vitreous State Laboratory
Glass Formulation Testing to Increase Sulfate Volatilization

Final Report, VSL-04R4970-1, Rev. 0

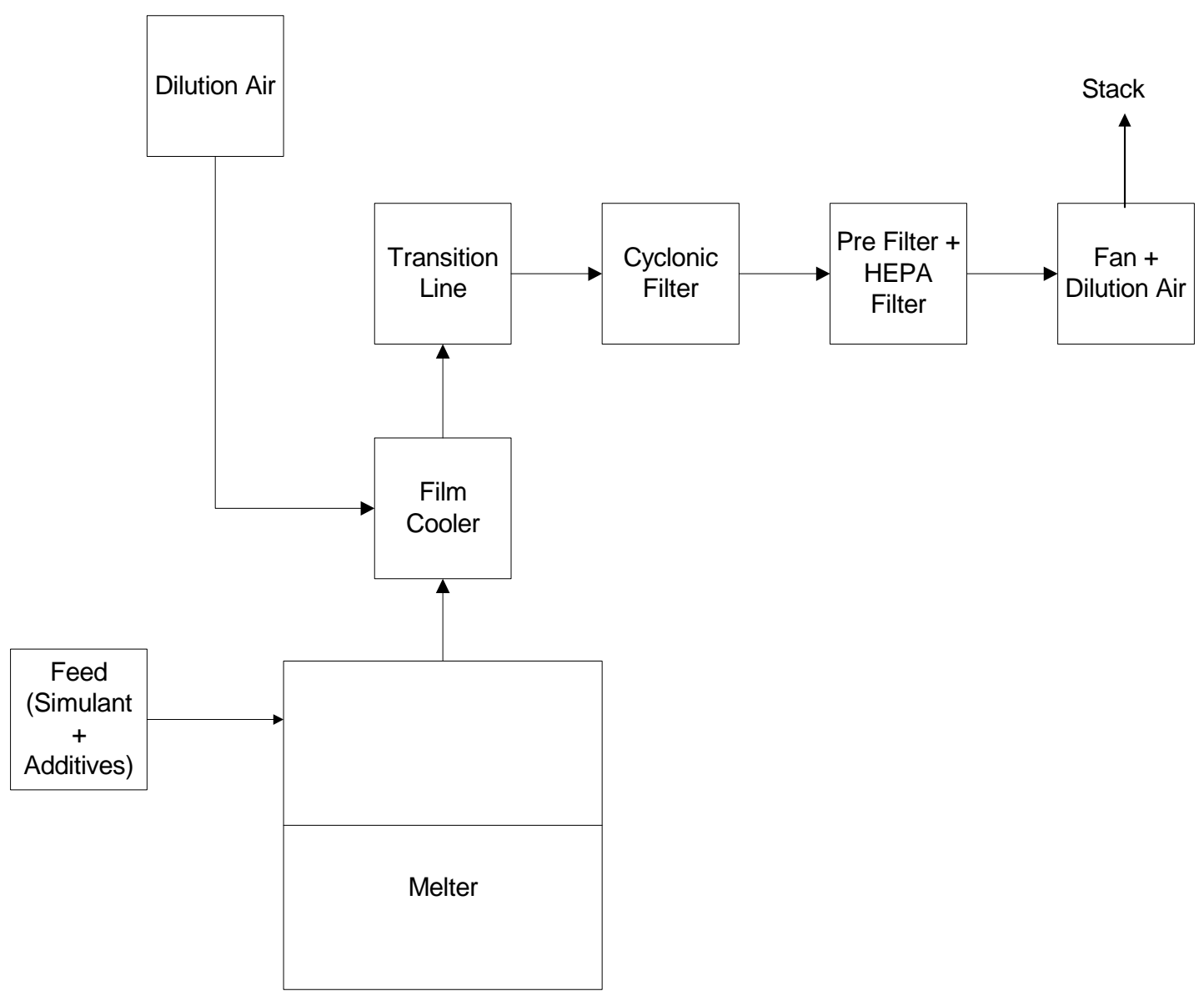

Figure 1.1. Schematic diagram of DuraMelter 100-WV vitrification system. 
The Catholic University of America Vitreous State Laboratory
Glass Formulation Testing to Increase Sulfate Volatilization Final Report, VSL-04R4970-1, Rev. 0

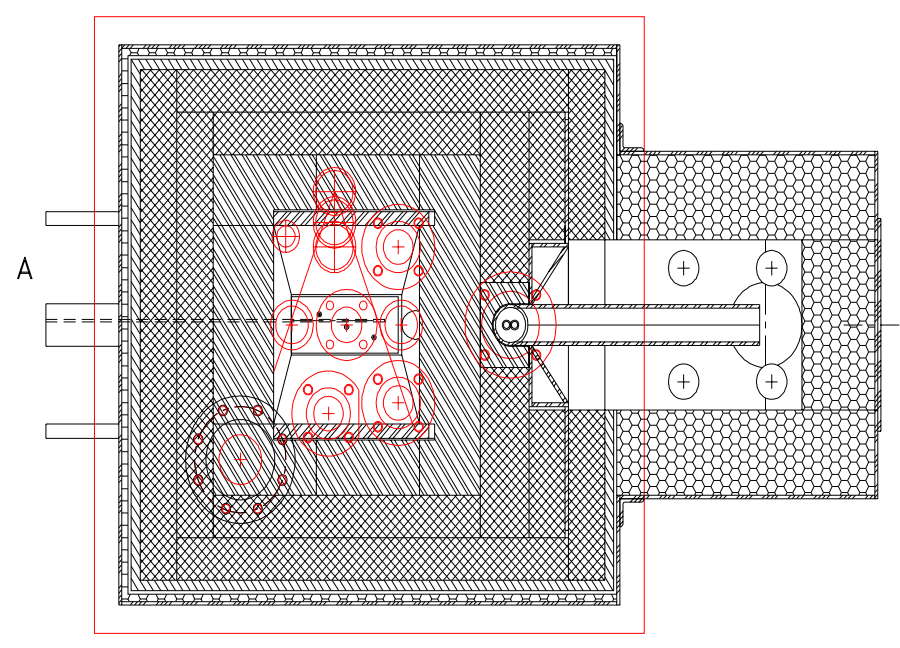

SECTION B-B

(BACKGROUND OMITTED)

Figure 1.2(a). Cross-section through the DM100-WV melter_ Plan View. 
The Catholic University of America Vitreous State Laboratory
Glass Formulation Testing to Increase Sulfate Volatilization Final Report, VSL-04R4970-1, Rev. 0

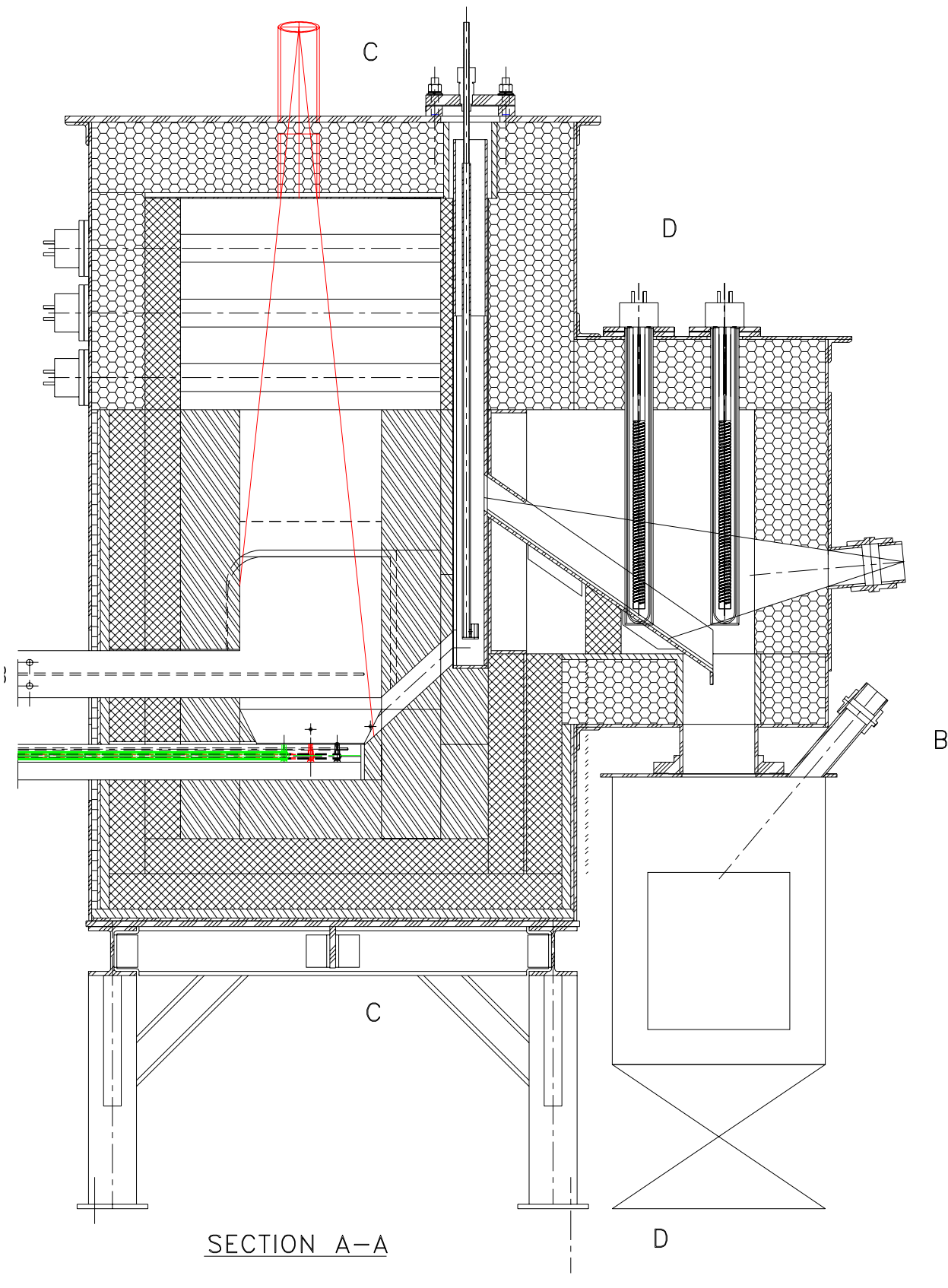

Figure 1.2(b). Cross-section through the DM100-WV melter-Section AA. 
The Catholic University of America Vitreous State Laboratory
Glass Formulation Testing to Increase Sulfate Volatilization Final Report, VSL-04R4970-1, Rev. 0

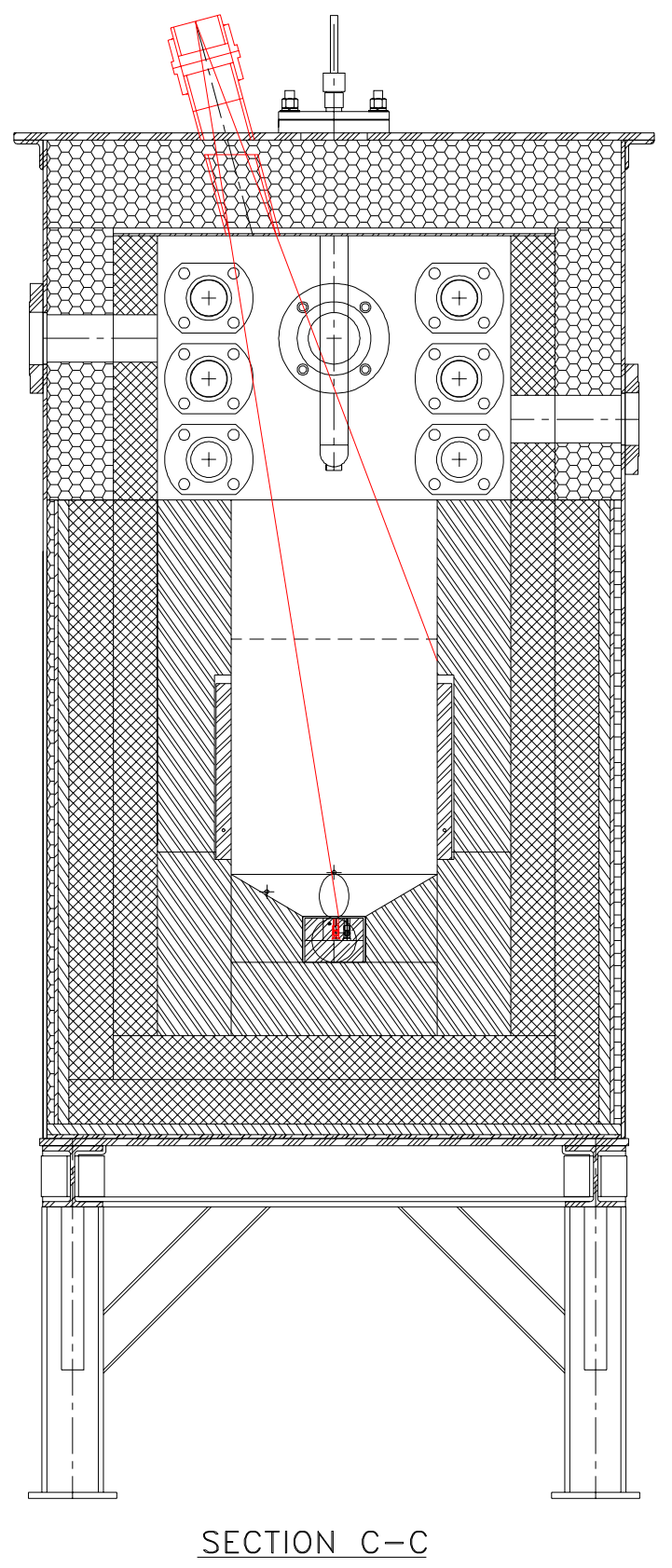

Figure 1.2(c). Cross-section through the DM100-WV melter-Section CC. 


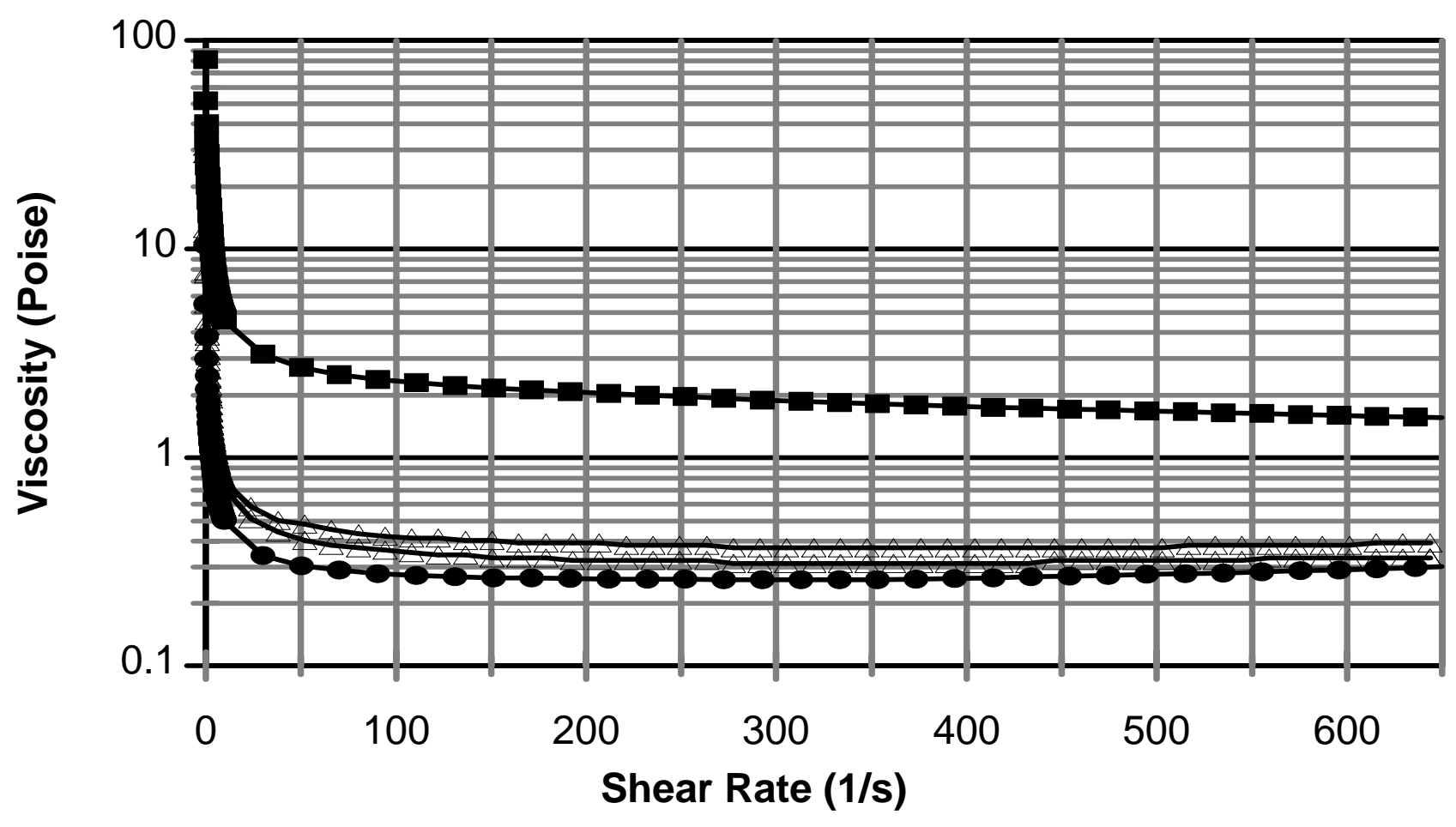

$\rightarrow$ Starch and Sugar
$\triangle$ Previous DM1200

Figure 2.1. Measured viscosity of LAW A melter feed samples. 

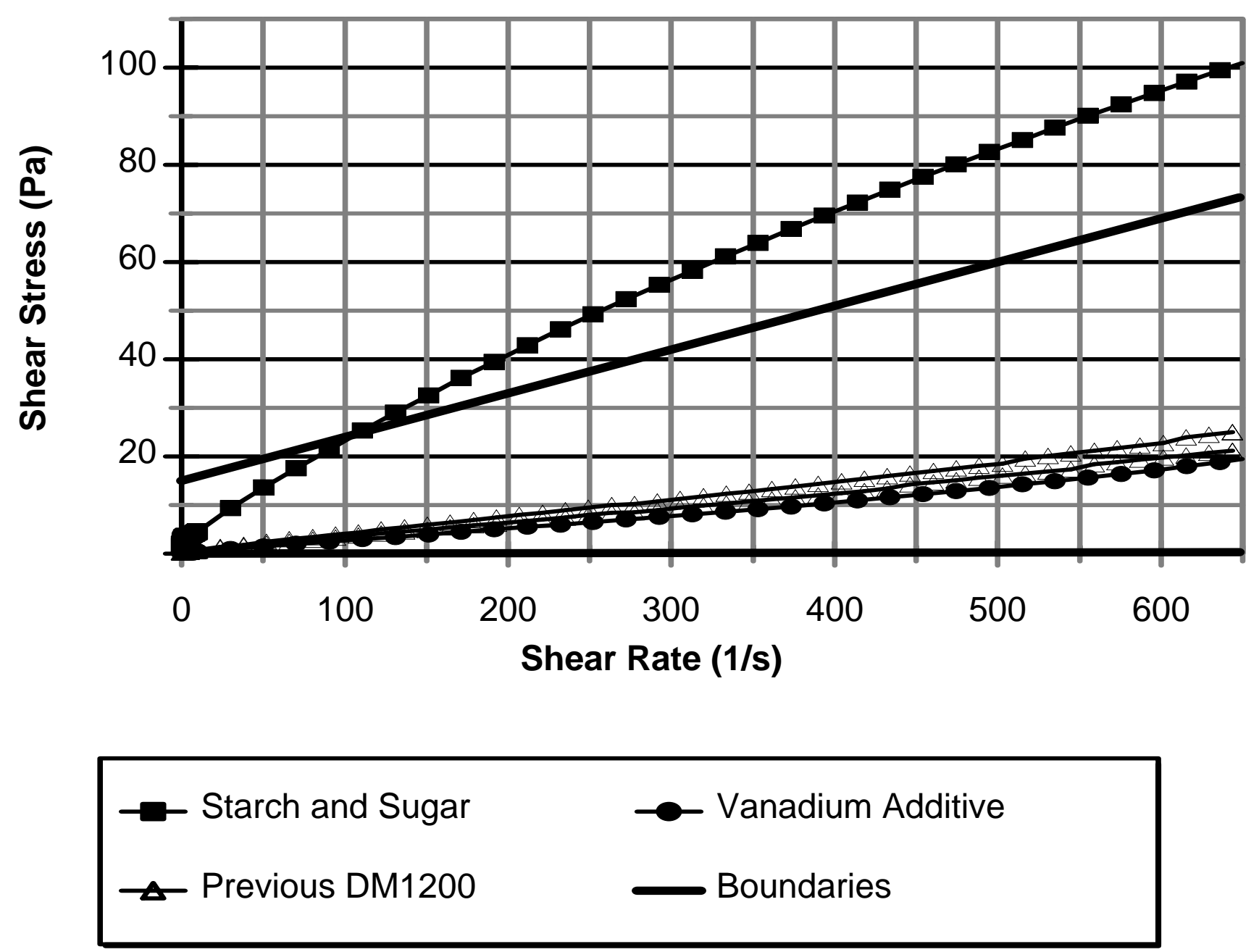

Figure 2.2. Comparison of measured feed rheology with proposed WTP bounds (bounds from WTP-RPT-075, Rev. 0, Feb. 2003). 


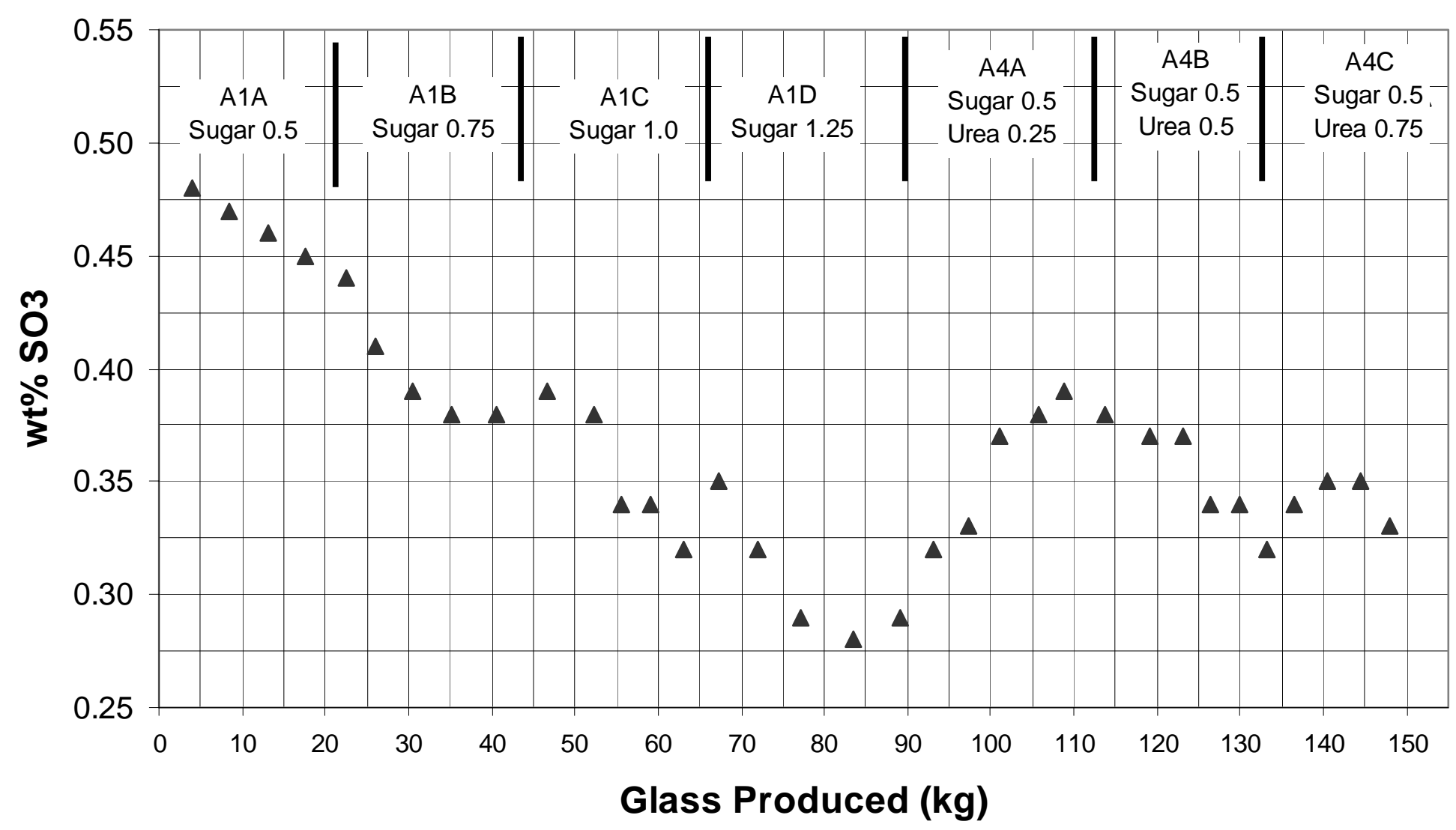

Figure 3.1. XRF analysis of sulfur in DM10 product glasses for tests with sugar and urea. 


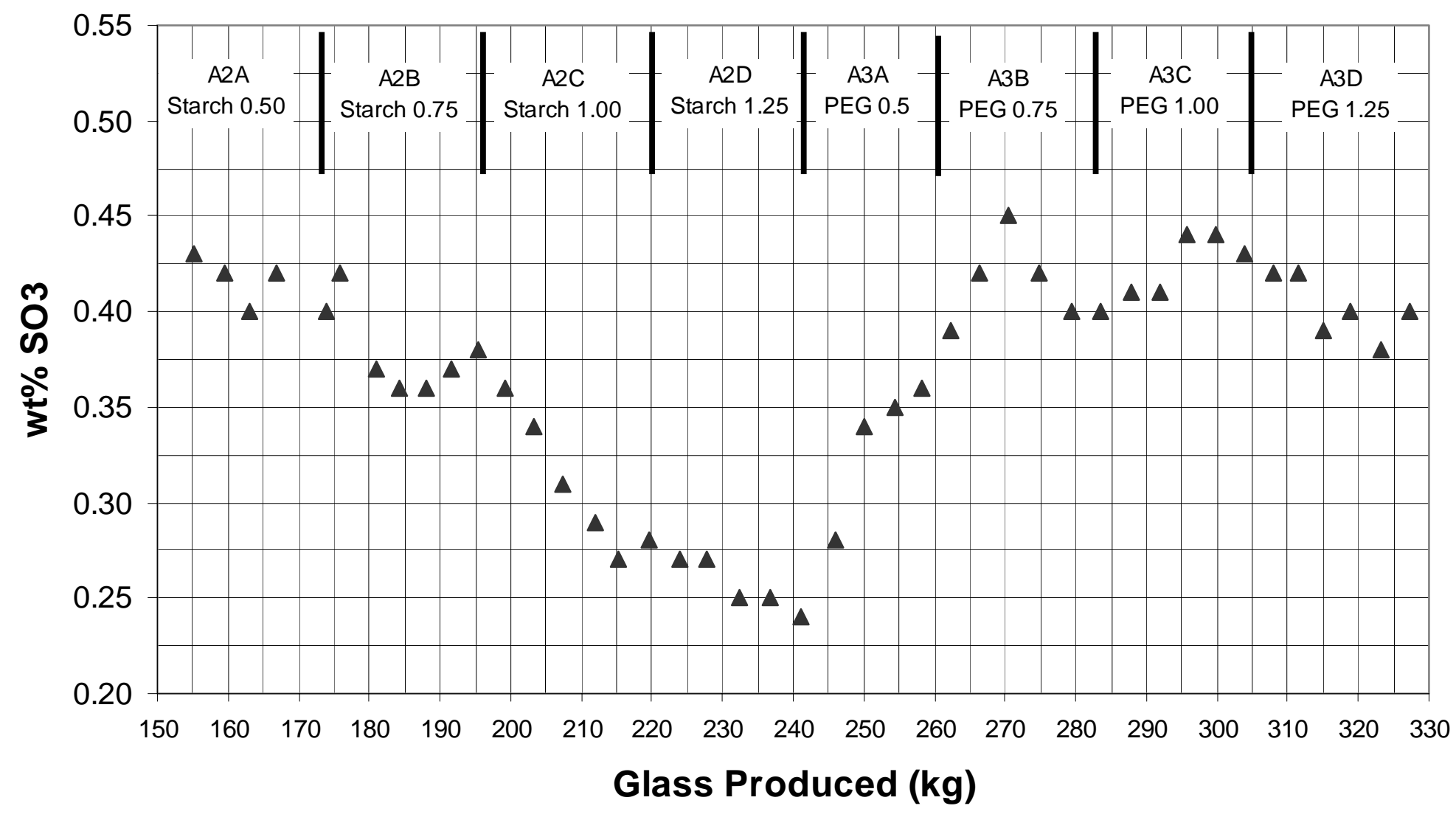

Figure 3.2. XRF analysis of sulfur in DM10 product glasses for tests with starch and PEG. 


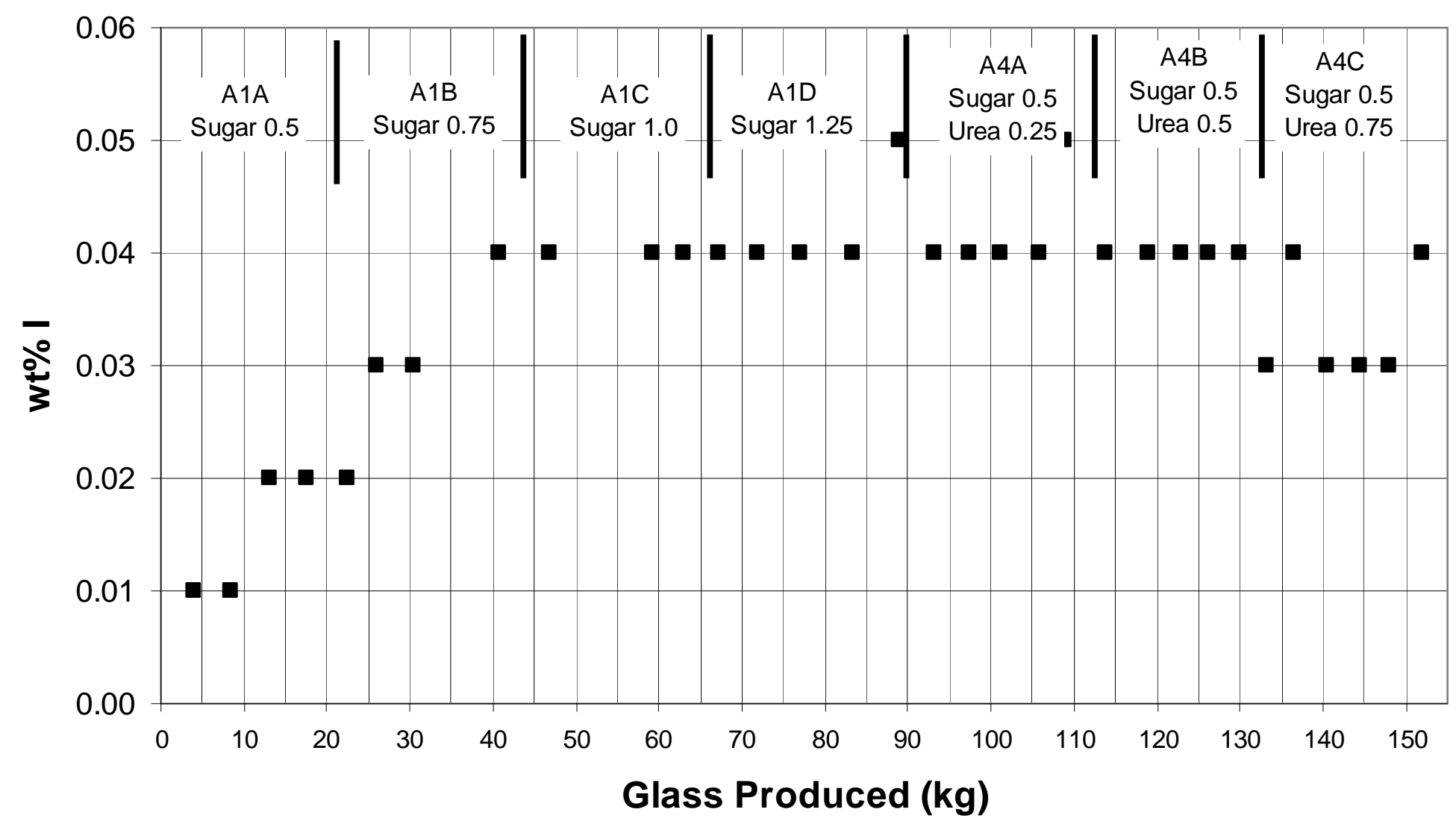

Figure 3.3. XRF analysis of iodine in DM10 product glasses for tests with sugar and urea. 


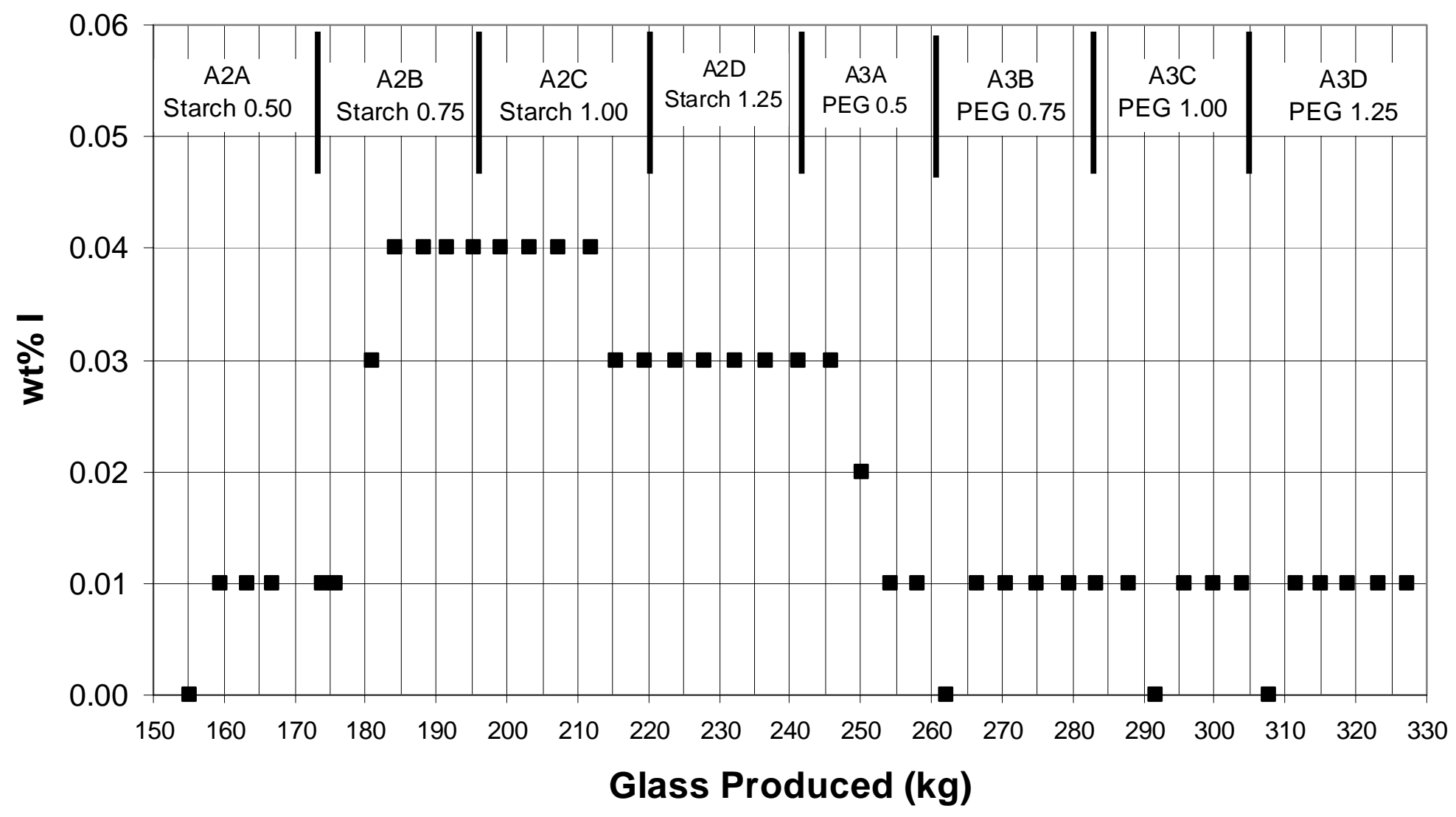

Figure 3.4. XRF analysis of iodine in DM10 product glasses for tests with starch and PEG. 


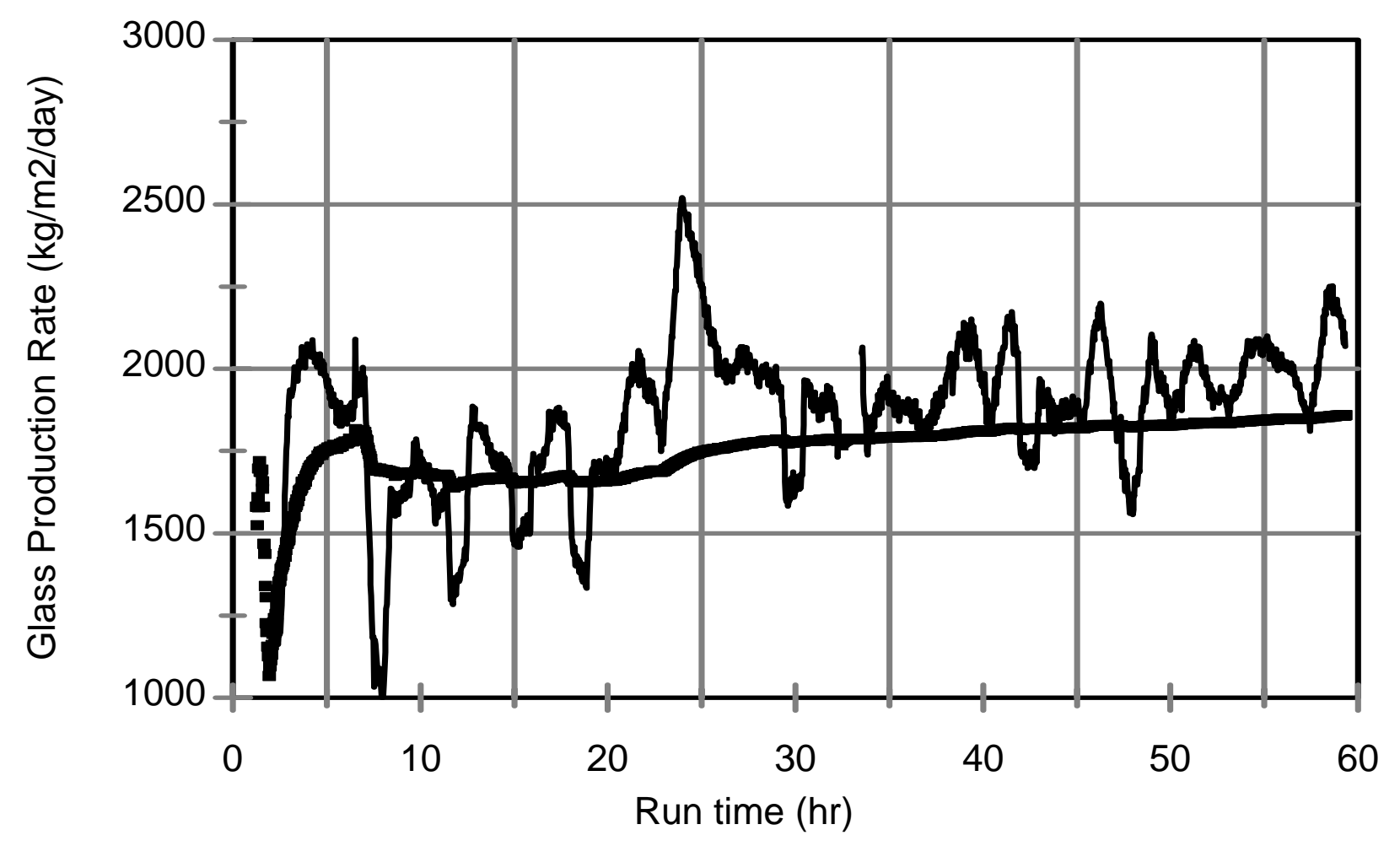

Figure 4.1.a. Glass production rate for the DM100 Urea and Sugar Test. 


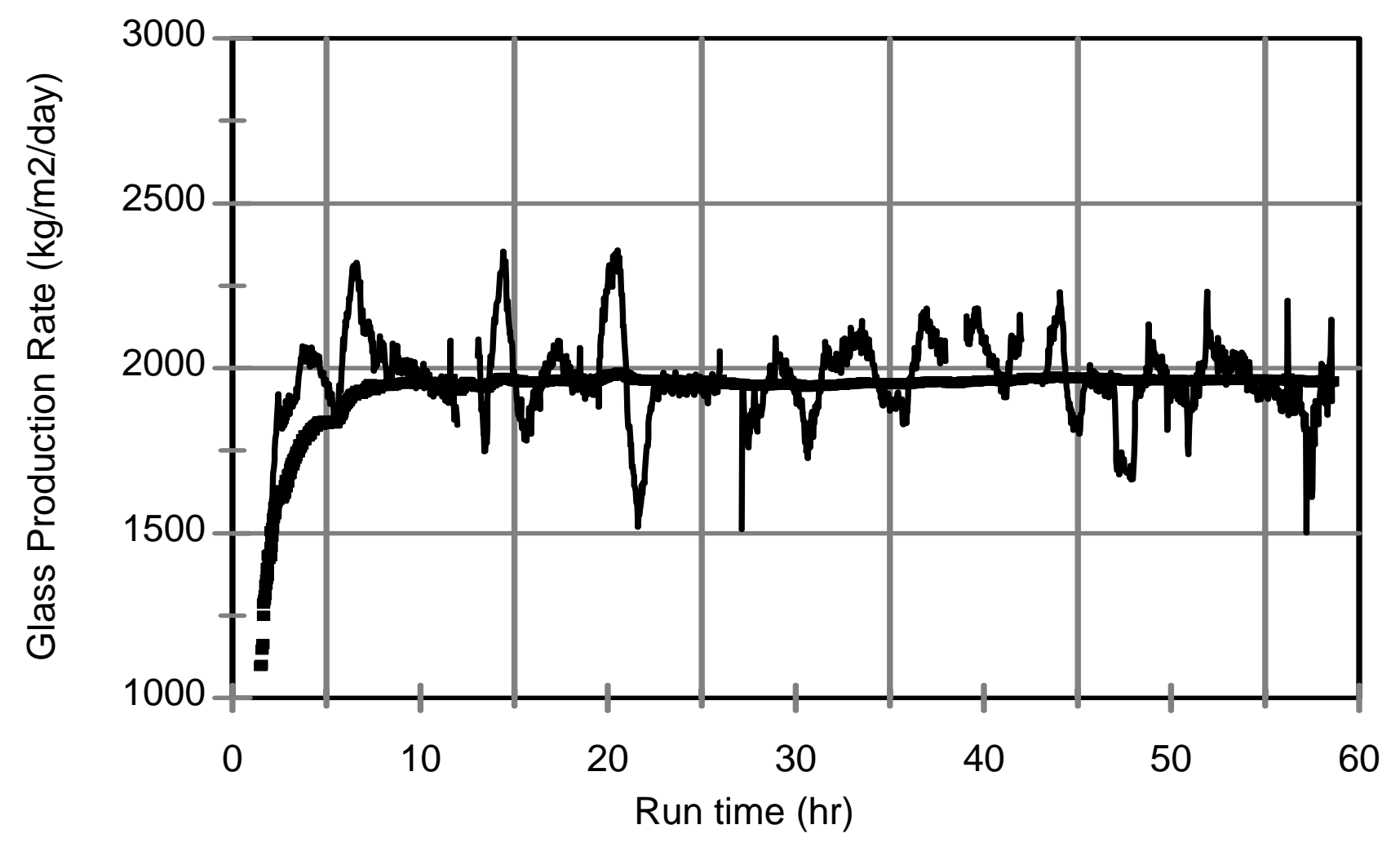

$1 \mathrm{hr}$ moving avg.

- Cumulative

Figure 4.1.b. Glass production rate for the DM100 Vanadium Additive Test. 


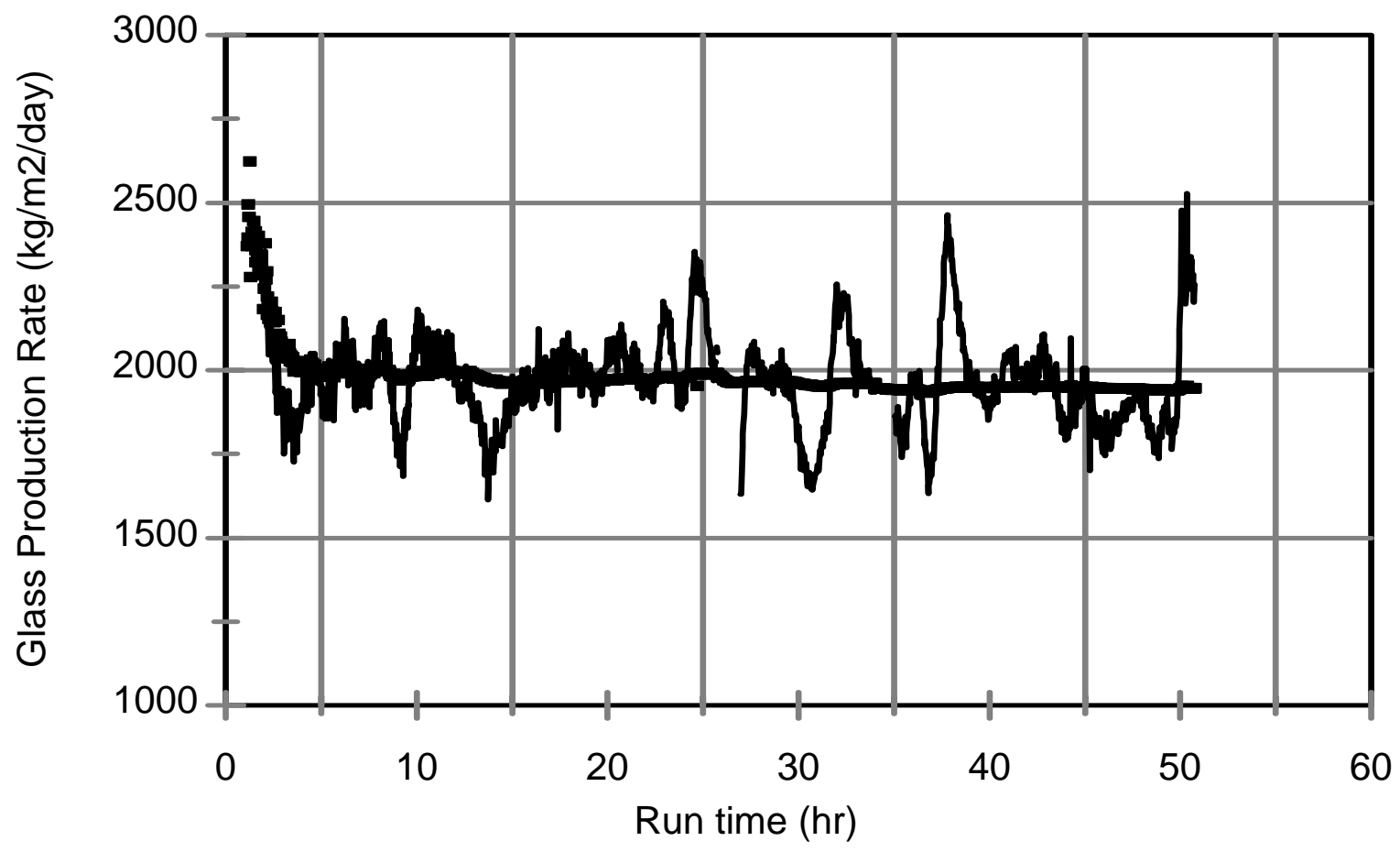

Figure 4.1.c. Glass production rate for the DM100 Starch and Sugar Test. 


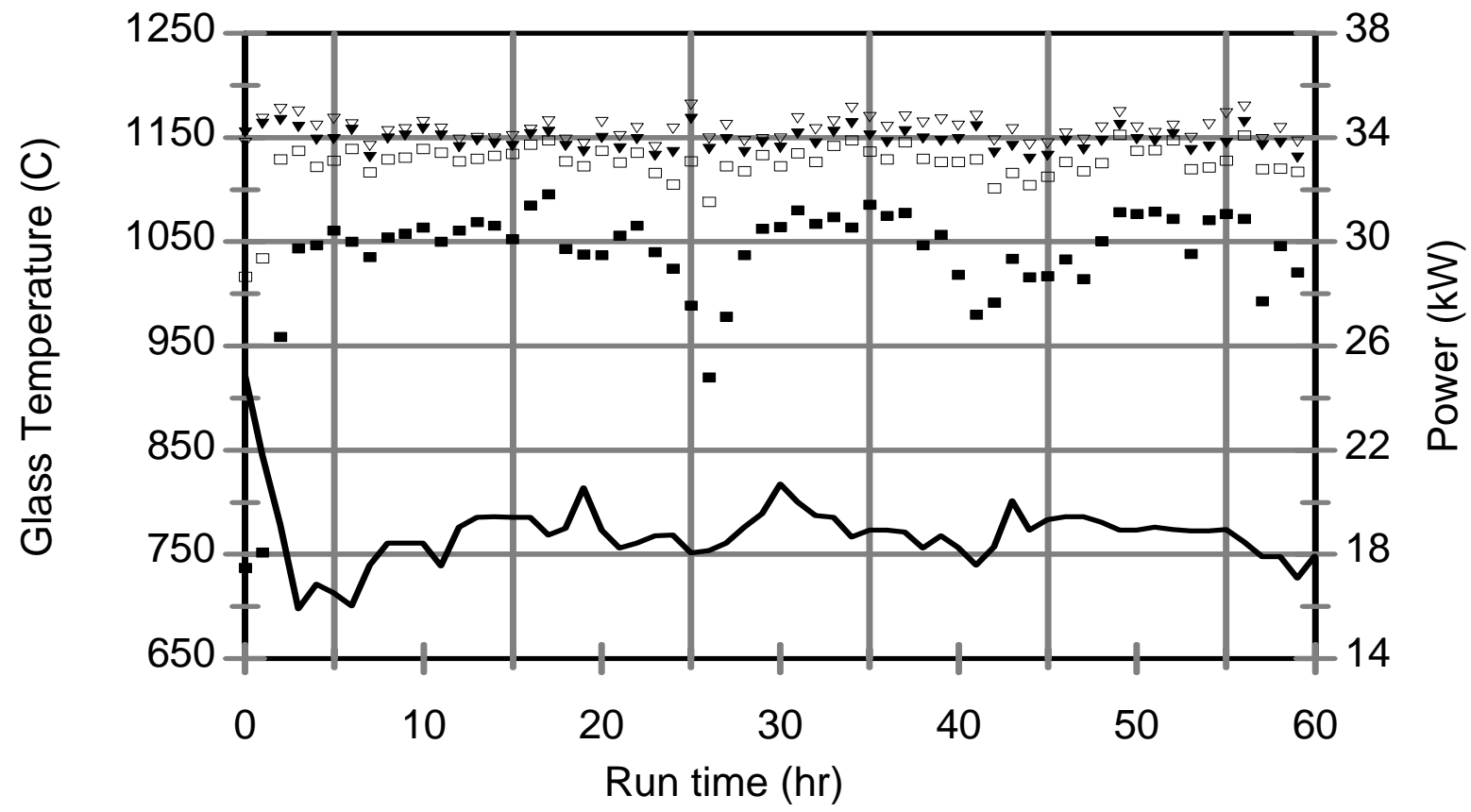

- $19 "$ from floor

- $16^{\prime \prime}$ from floor

- 10 "from floor

- 4" from floor Power

Figure 4.2.a. Glass temperatures and electrode power for the DM100 Urea and Sugar Test. 


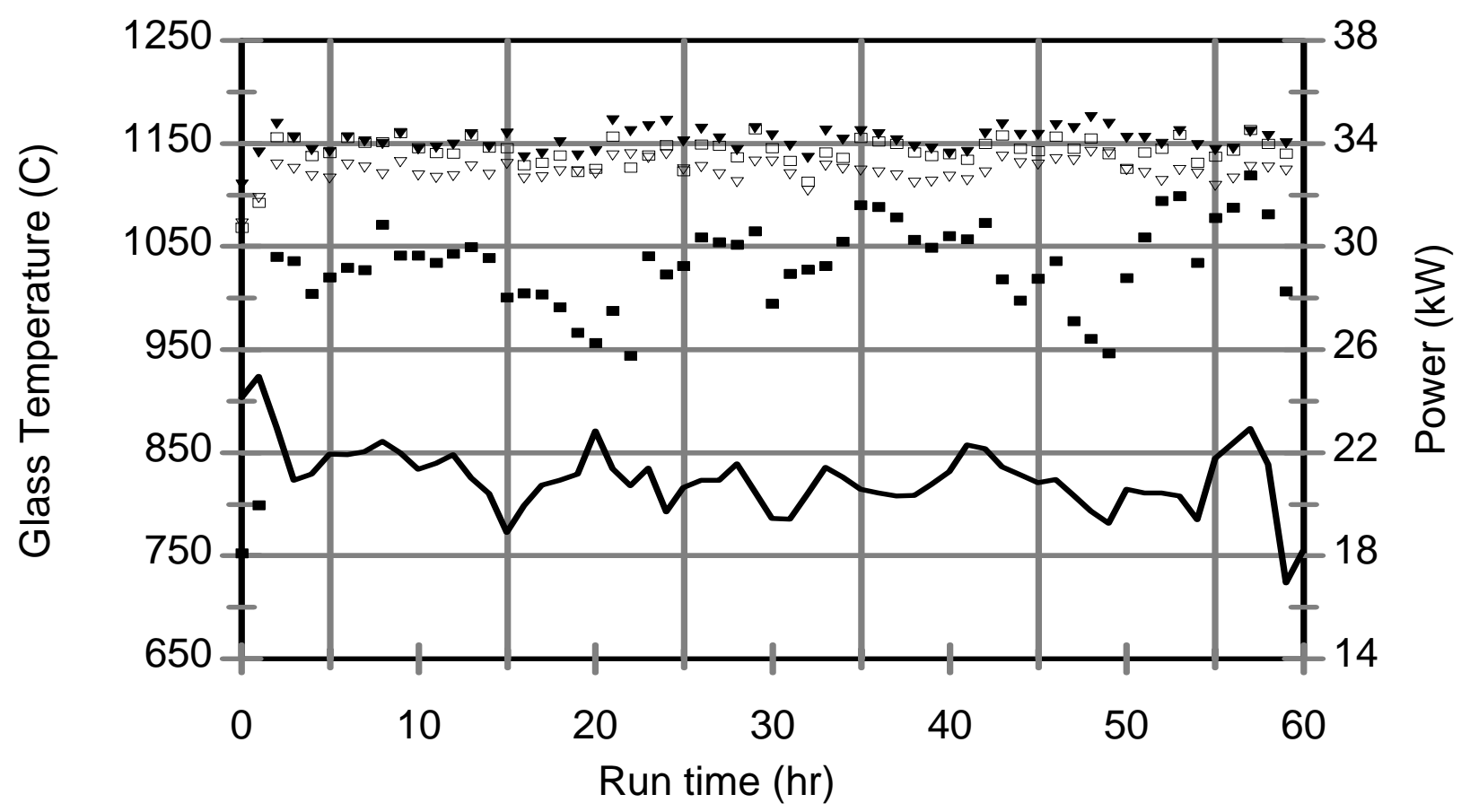

- $19 "$ from floor

- 16 "from floor

- 10 " from floor

- 4" from floor

- Power

Figure 4.2.b. Glass temperatures and electrode power for the DM100 Vanadium Additive Test. 


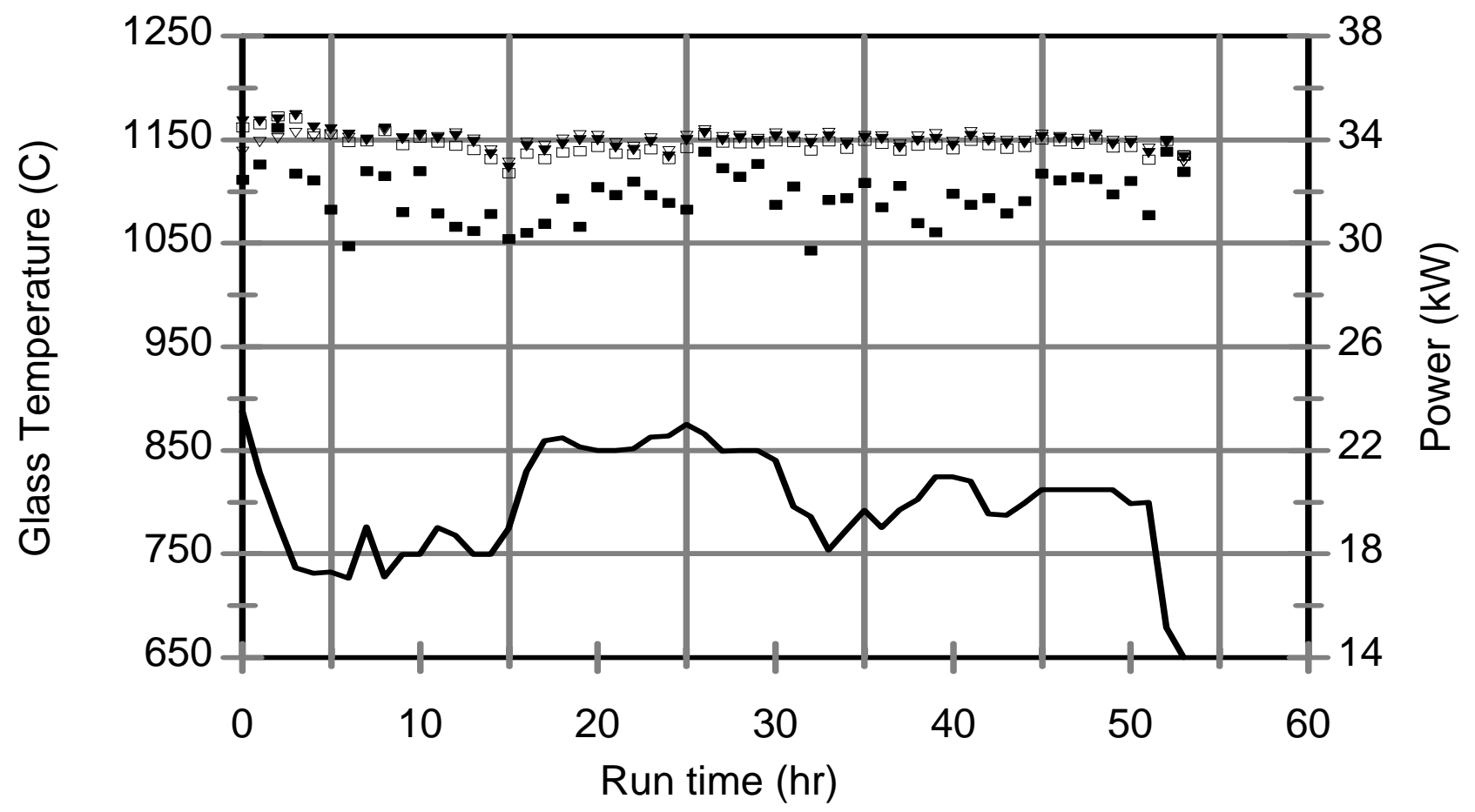

- $19 "$ from floor

- 16 " from floor

- 10 " from floor

- 4" from floor

- Power

Figure 4.2.c. Glass temperatures and electrode power for the DM100 Starch and Sugar Test. 


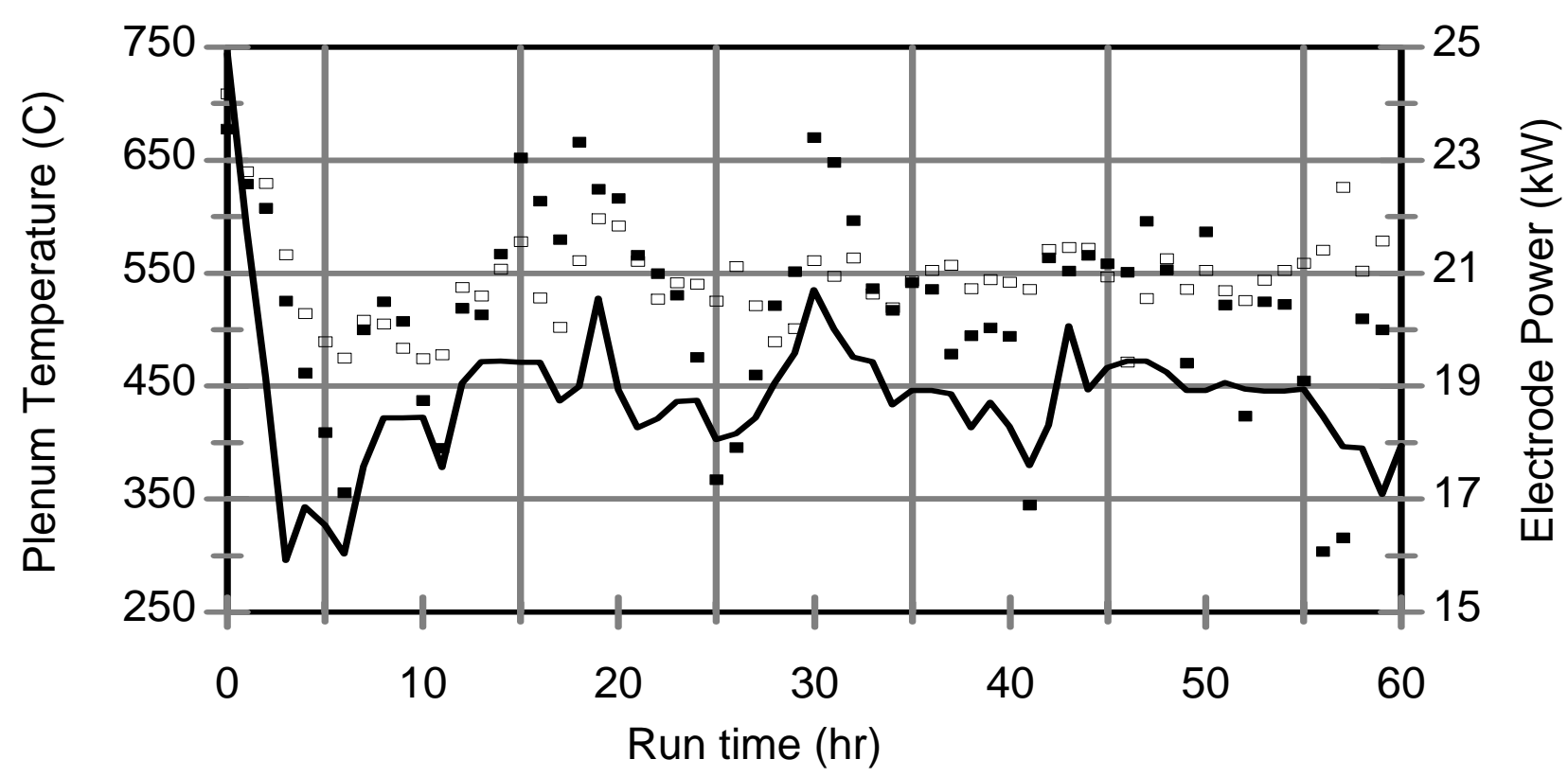

- $16 "$ below ceiling (exposed)

- 16 " below ceiling (thermowell) Electrode Power

Figure 4.3.a. Plenum temperatures and electrode power for the DM100 Urea and Sugar Test. 


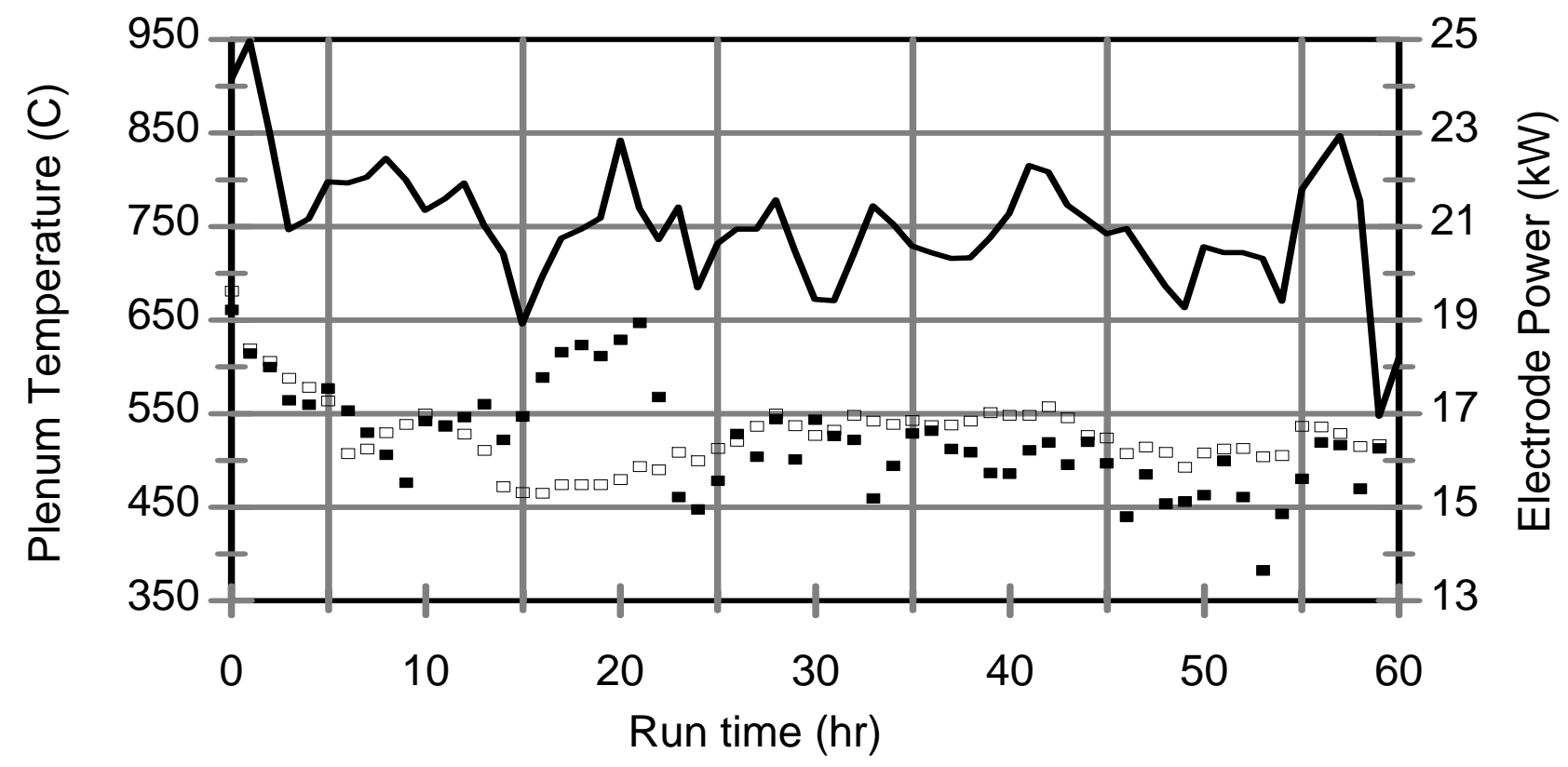

- 16 " below ceiling (exposed)

- 16 " below ceiling (thermowell) Electrode Power

Figure 4.3.b. Plenum temperatures and electrode power for the DM100 Vanadium Additive Test. 


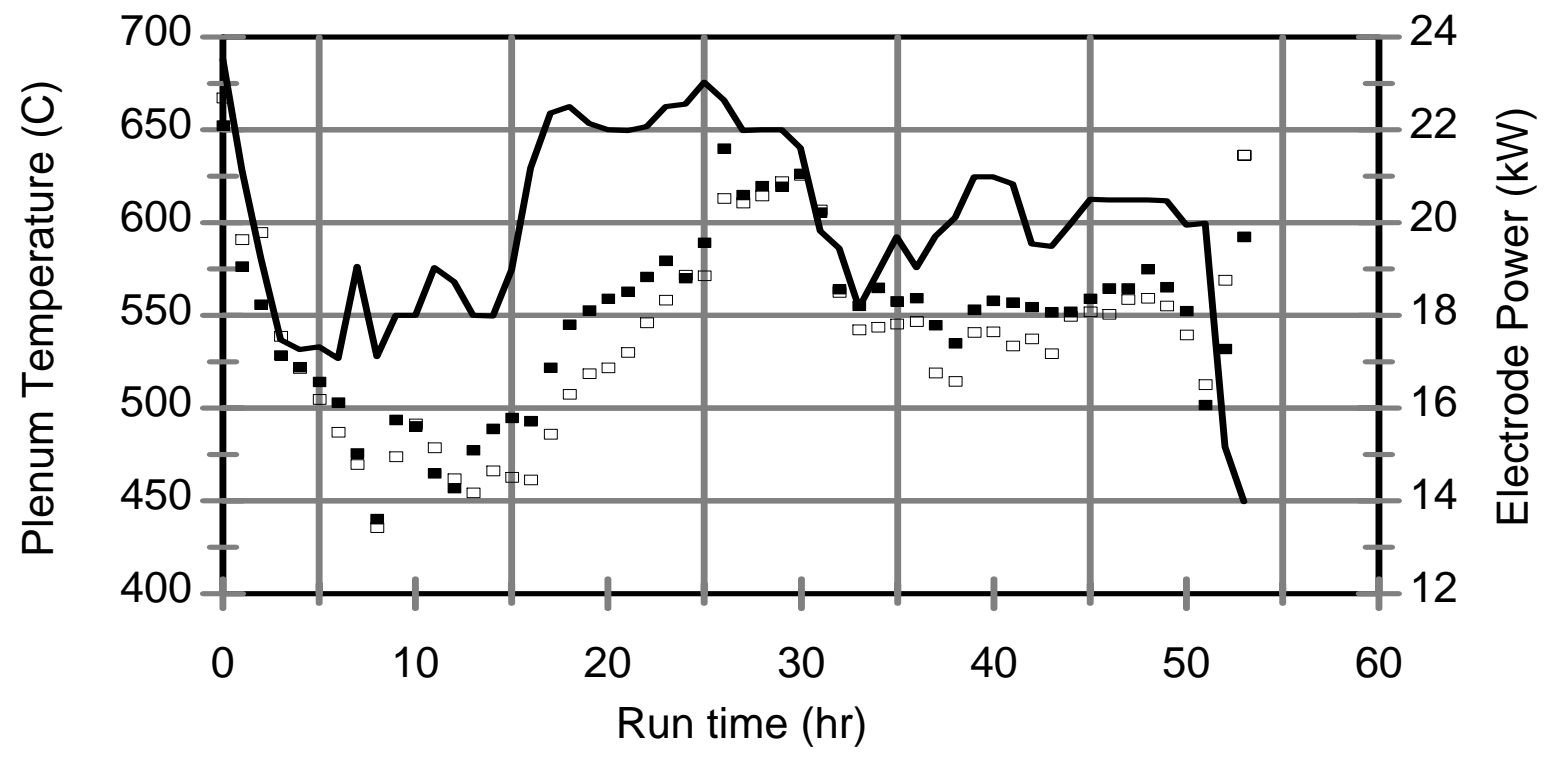

- $16 "$ below ceiling (exposed)

- 16 " below ceiling (thermowell) Electrode Power

Figure 4.3.c. Plenum temperatures and electrode power for the DM100 Starch and Sugar Test. 


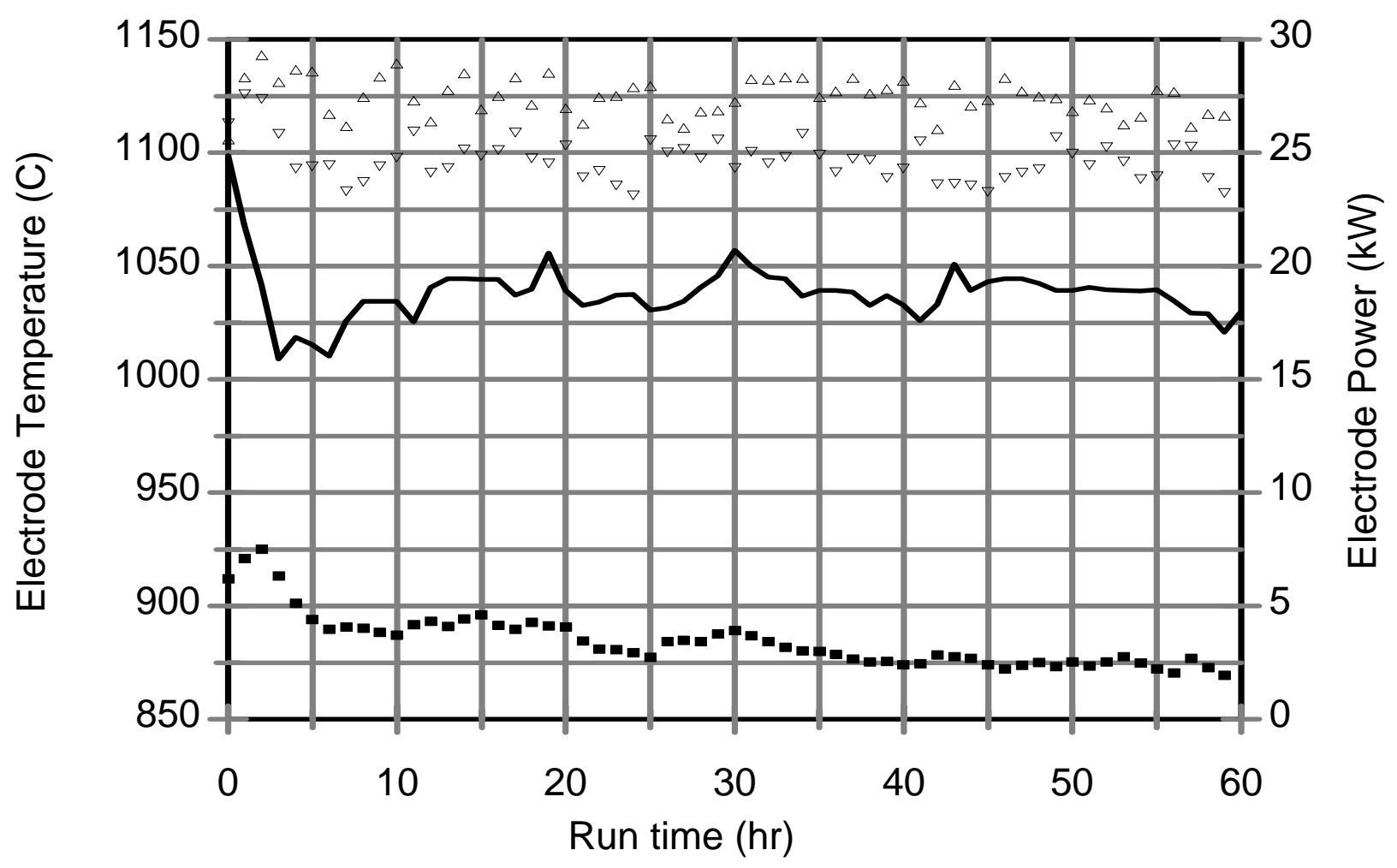

Figure 4.4.a. Electrode temperatures and power for the DM100 Urea and Sugar Test. 


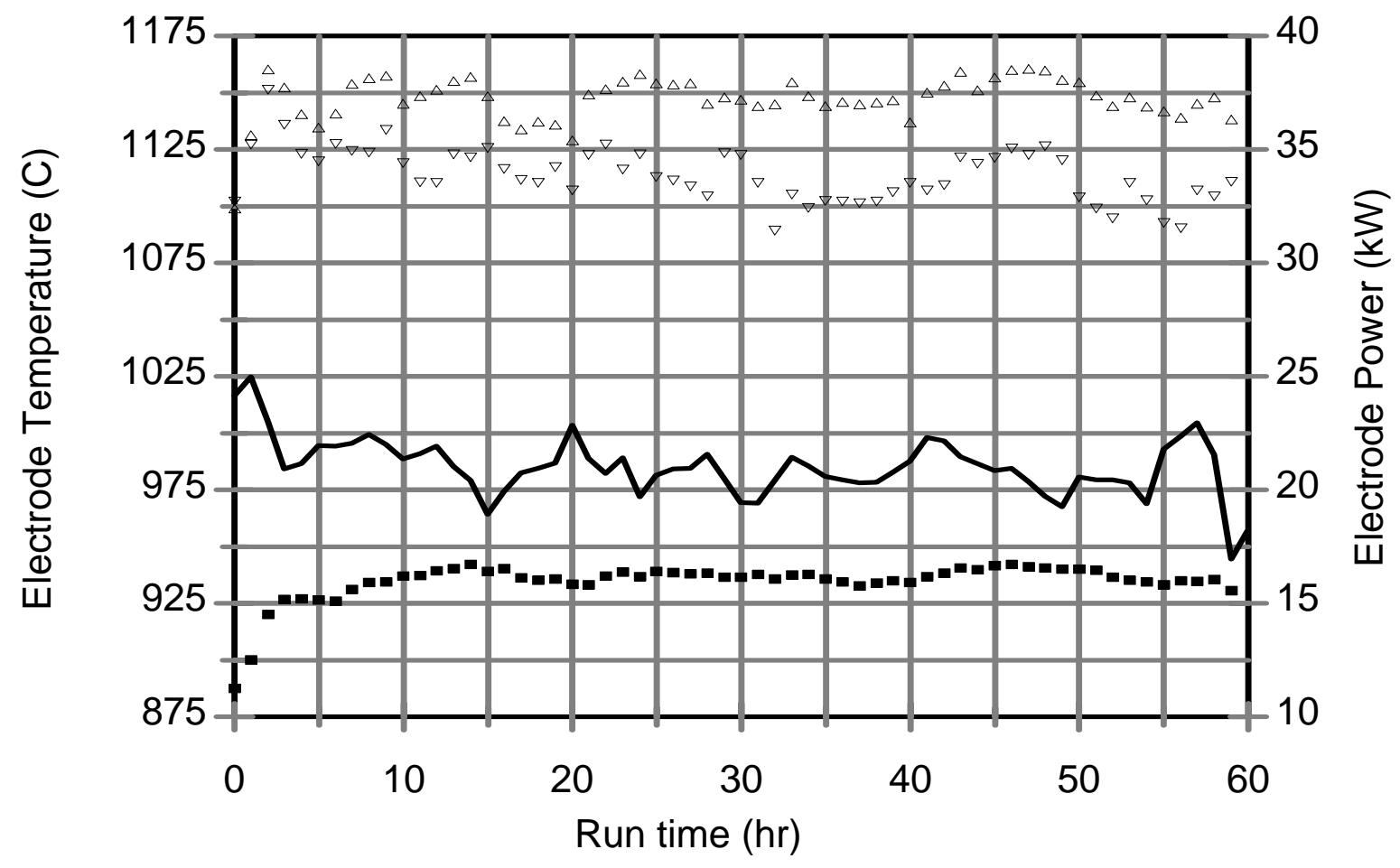

Figure 4.4.b. Electrode temperatures and power for the DM100 Vanadium Additive Test. 


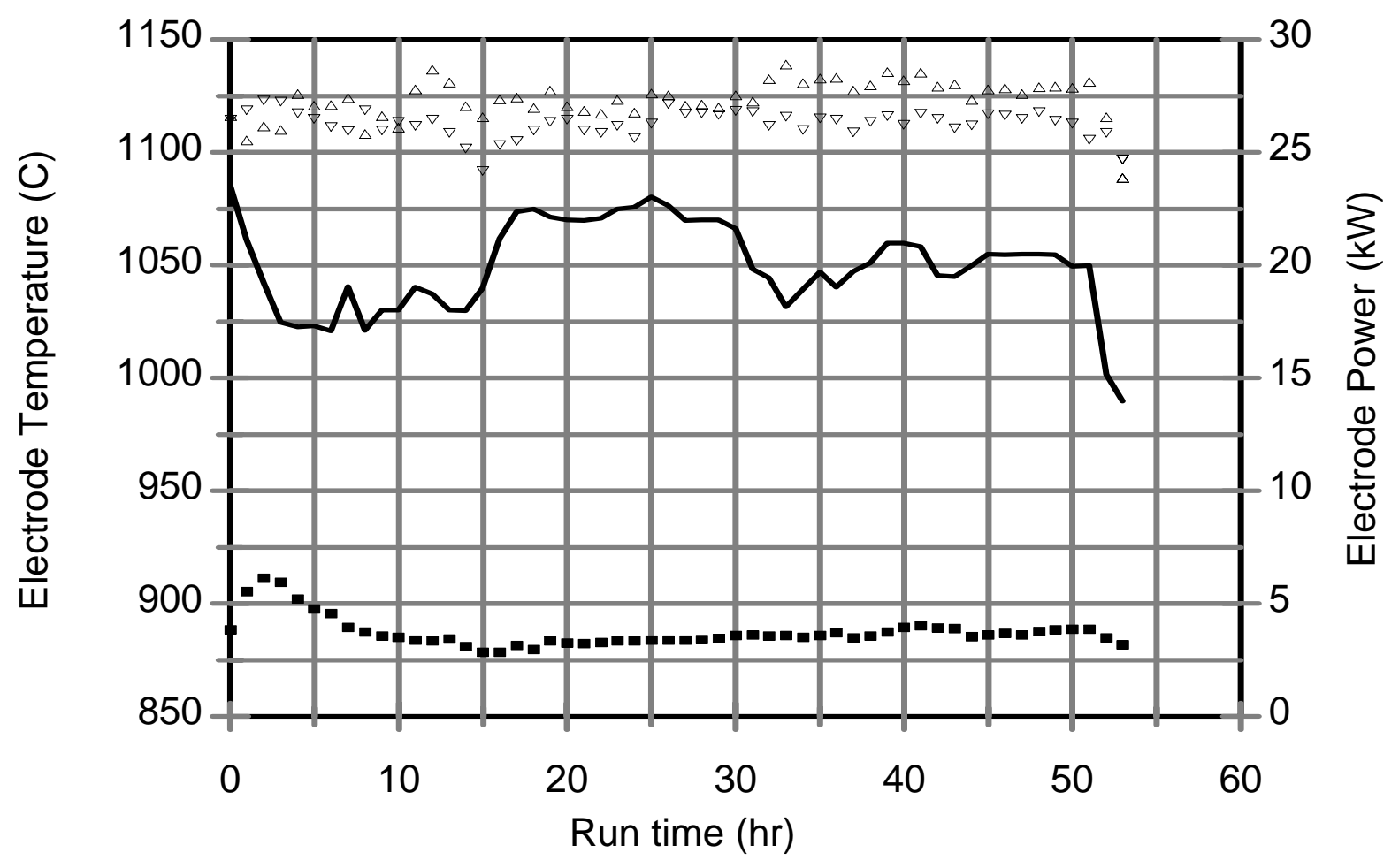
- East
- West
- Bottom
Power

Figure 4.4.c. Electrode temperatures and power for the DM100 Starch and Sugar Test. 


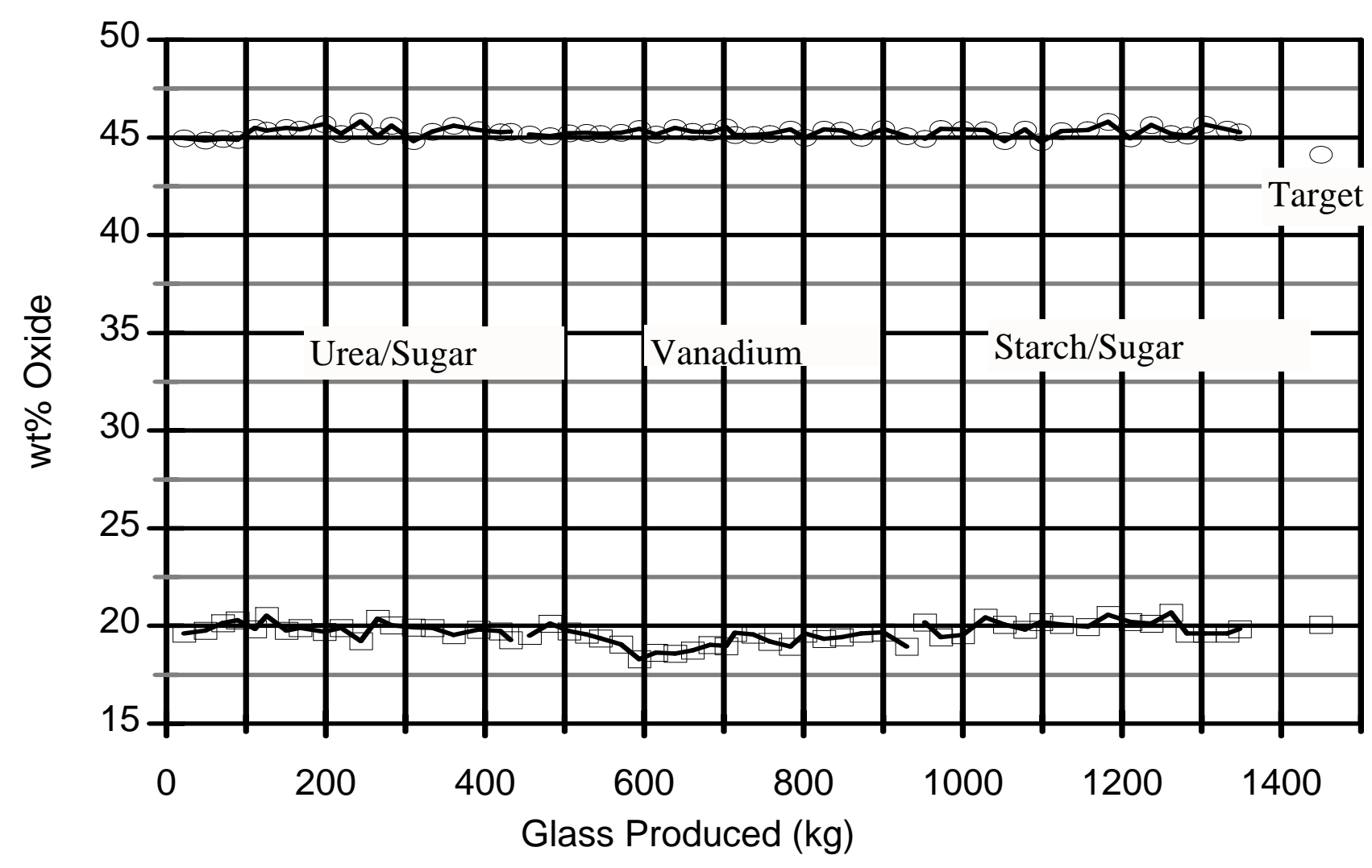

Figure 5.1. XRF analysis of $\mathrm{Na}_{2} \mathrm{O}$ and $\mathrm{SiO}_{2}$ in $\mathrm{DM100}$ product glasses. 


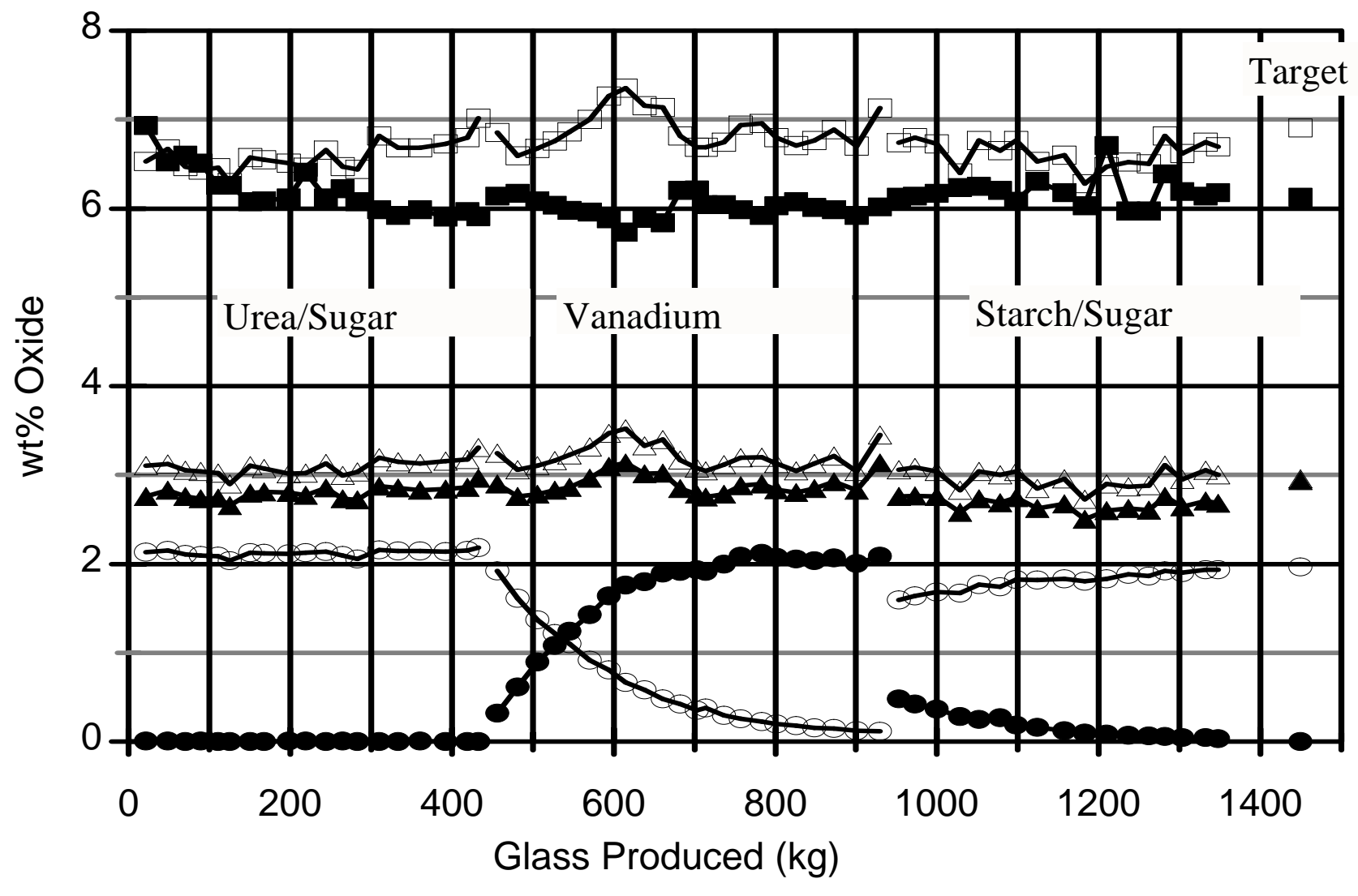

Figure 5.2. XRF analysis of select major oxides in DM100 product glasses. 


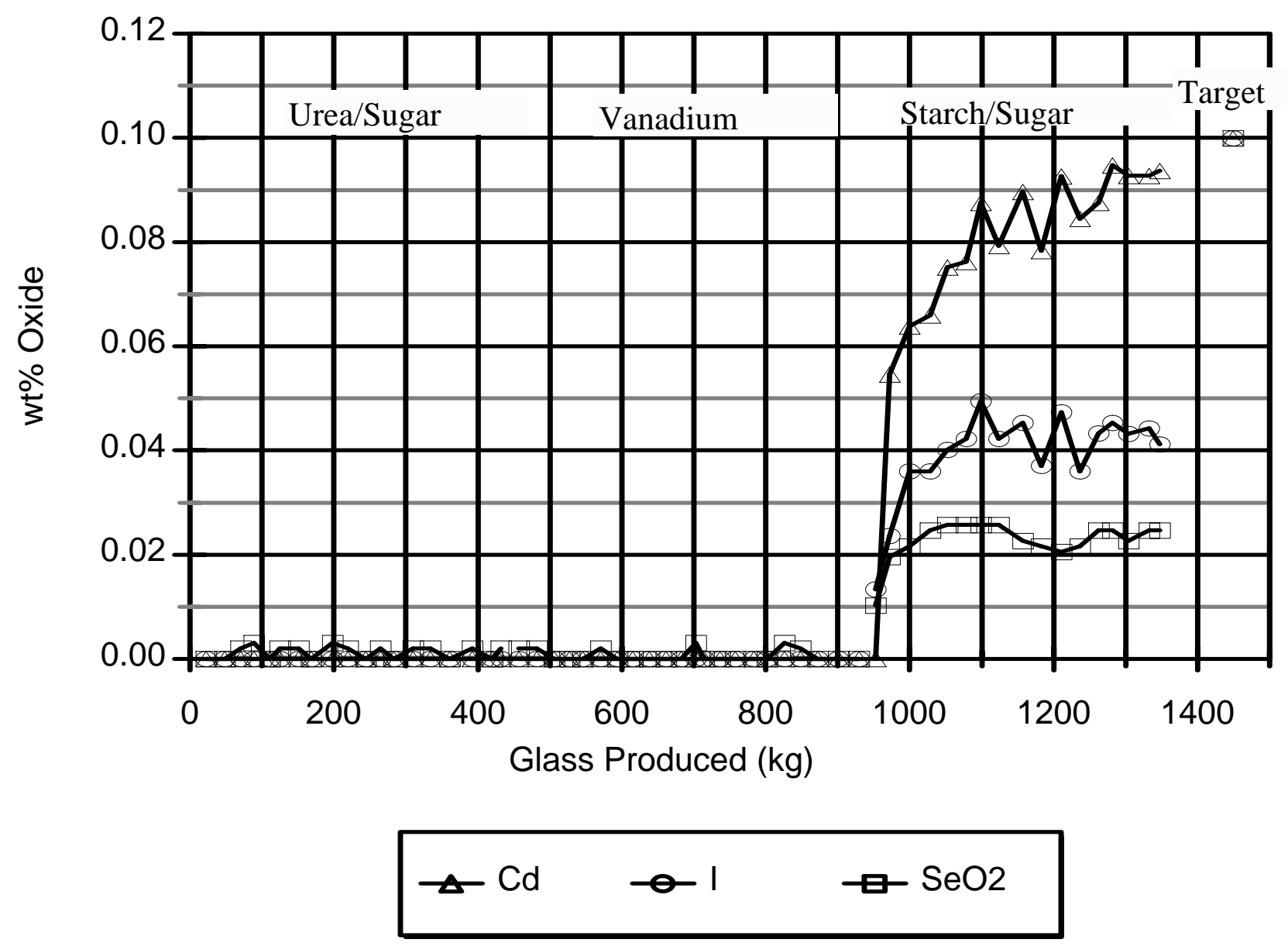

Figure 5.3. XRF analysis of spiked oxides in DM100 product glasses. 


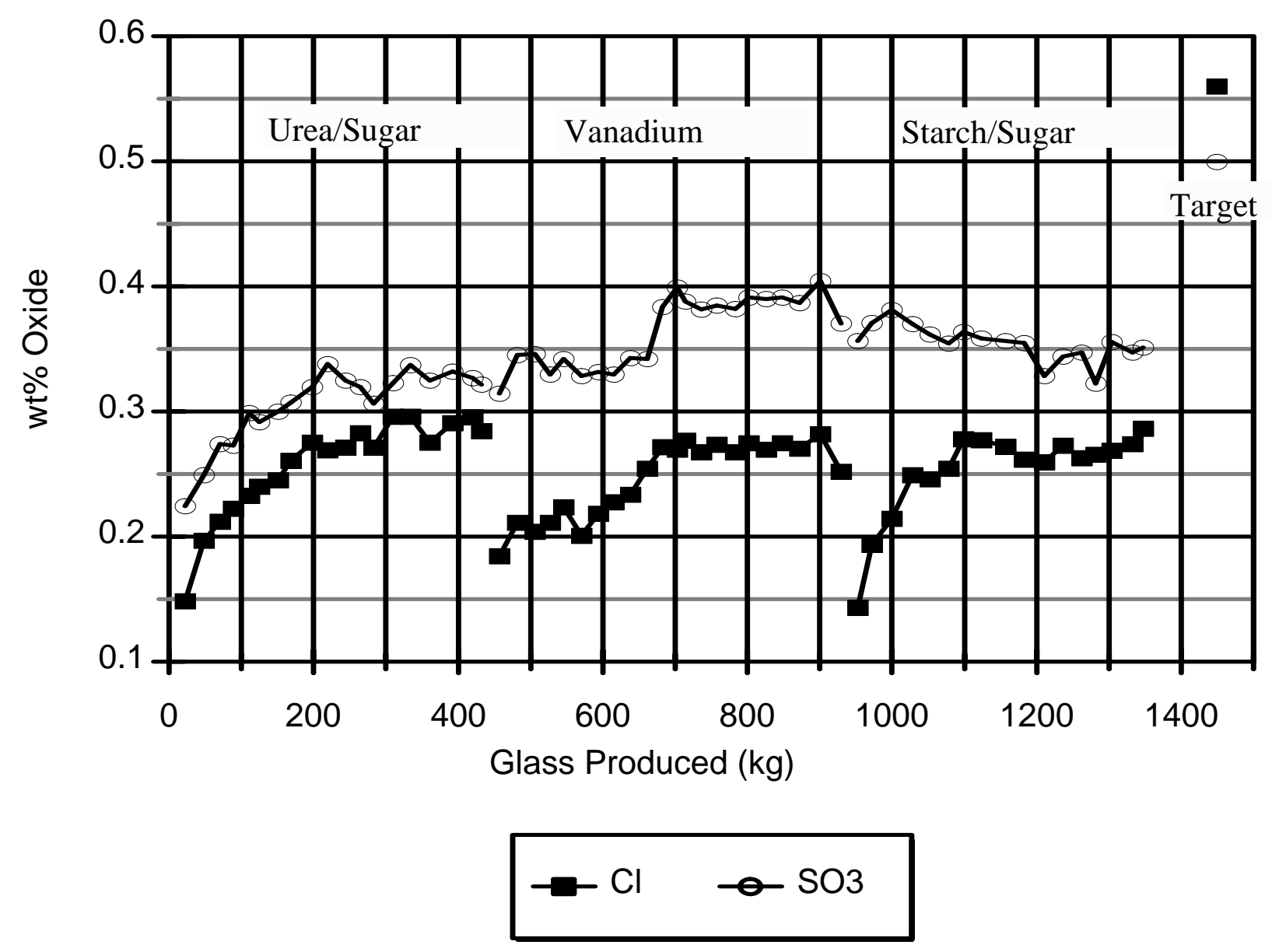

Figure 5.4. XRF analysis of chlorine and sulfur in DM100 product glasses. 


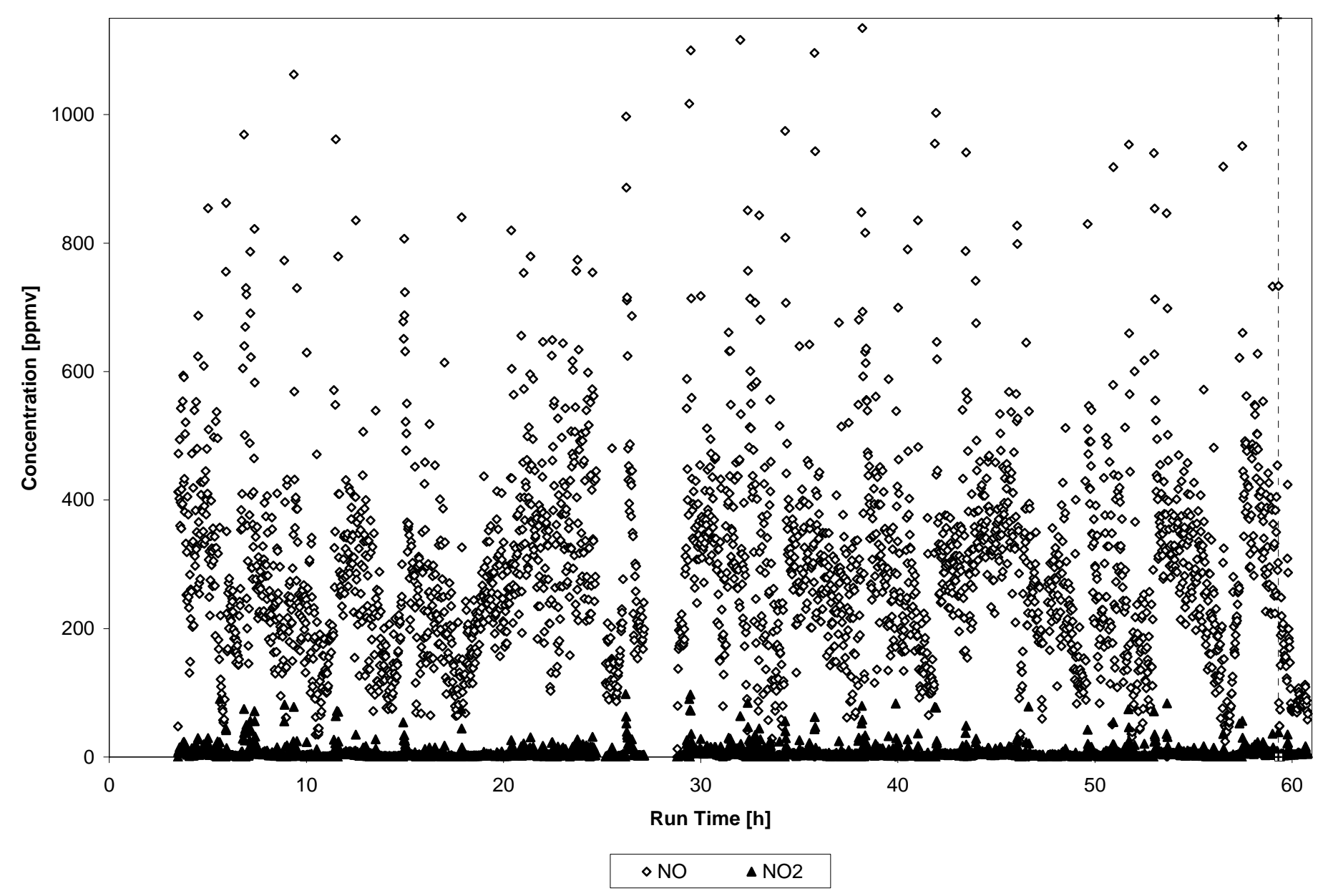

Figure 6.1.a. Nitrogen oxide concentrations in off-gas from FTIR for the DM100 Urea and Sugar Test. 


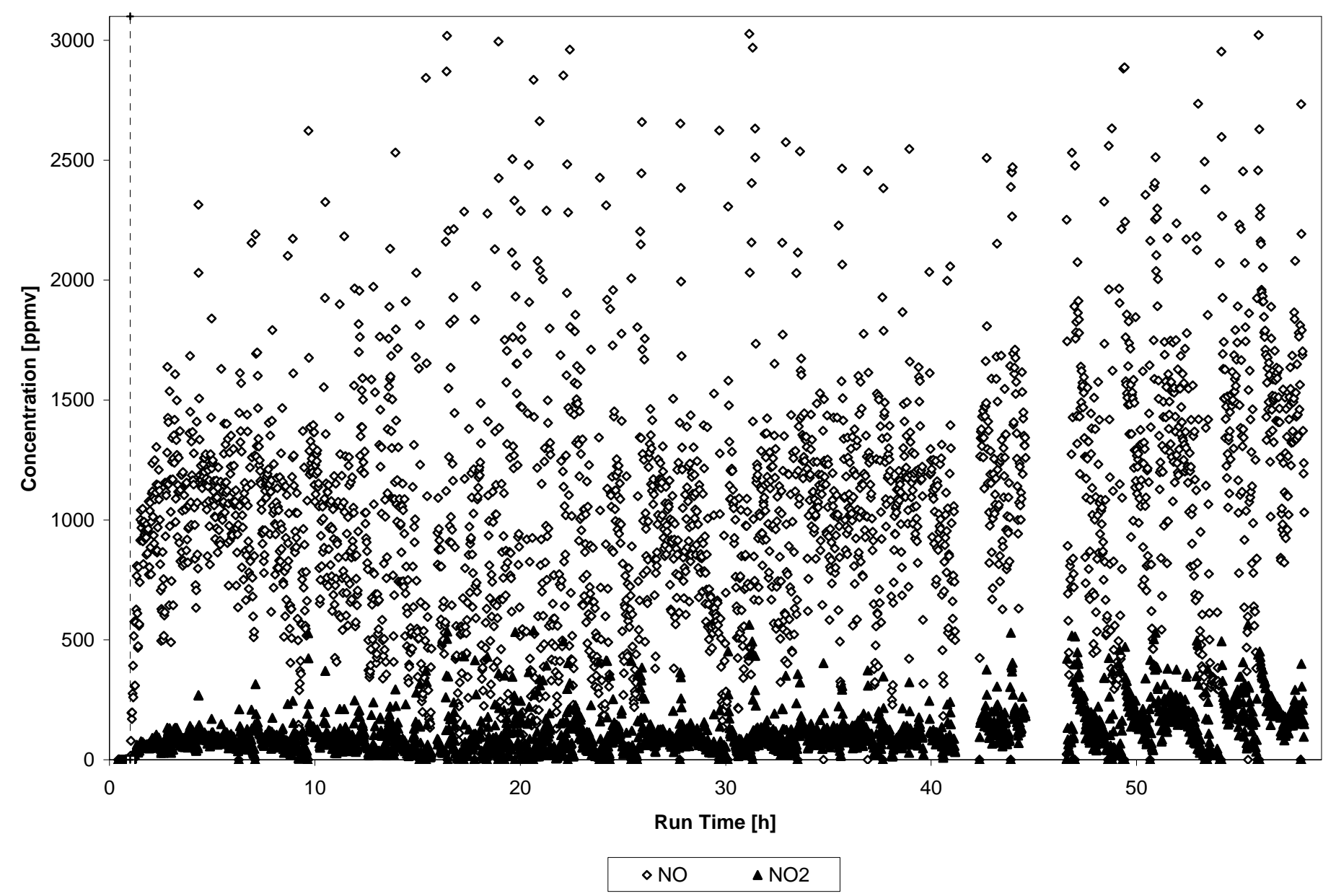

Figure 6.1.b. Nitrogen oxide concentrations in off-gas from FTIR for the DM100 Vanadium Additive Test. 


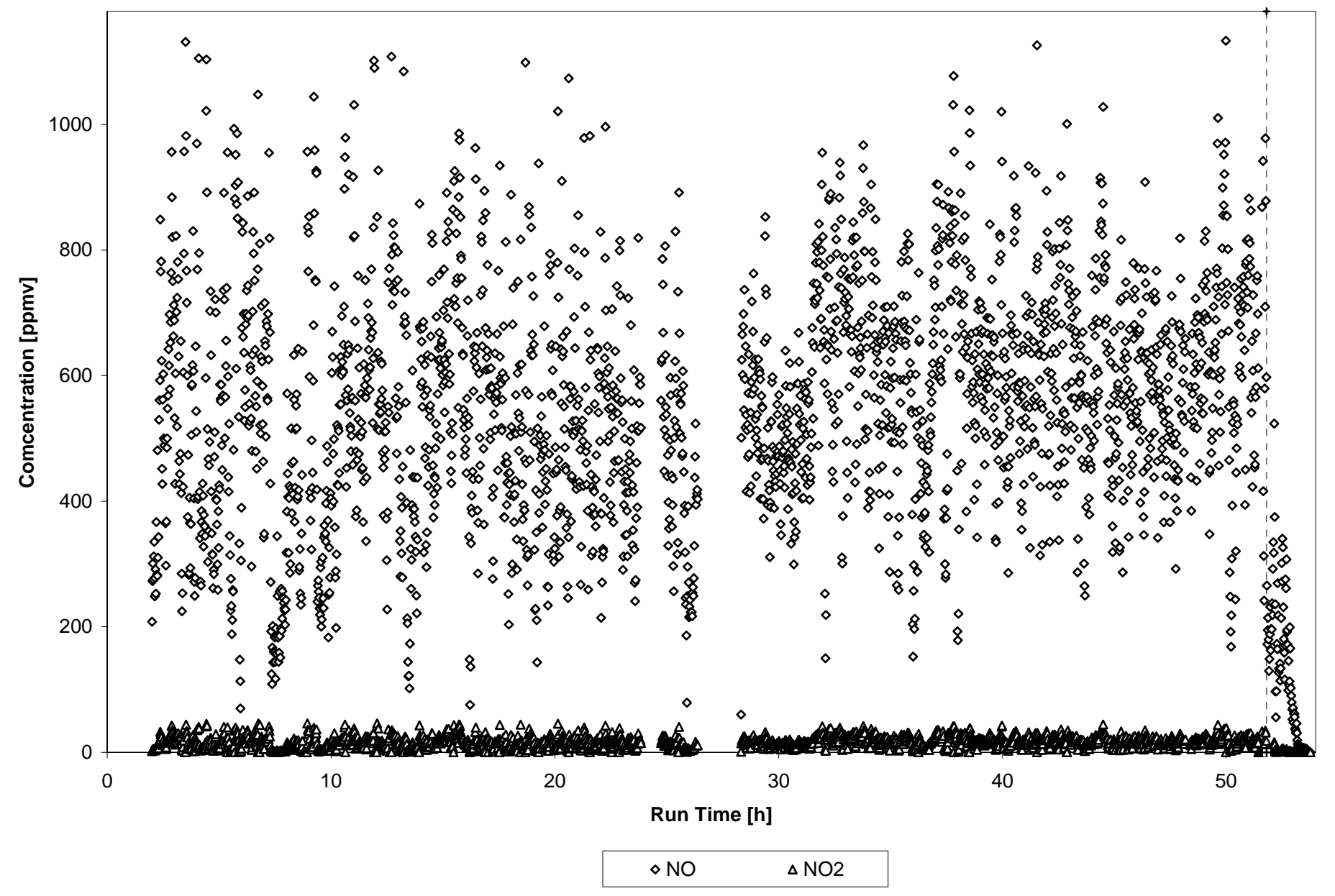

Figure 6.1.c. Nitrogen oxide concentrations in off-gas from FTIR for the DM100 Starch and Sugar Test. 


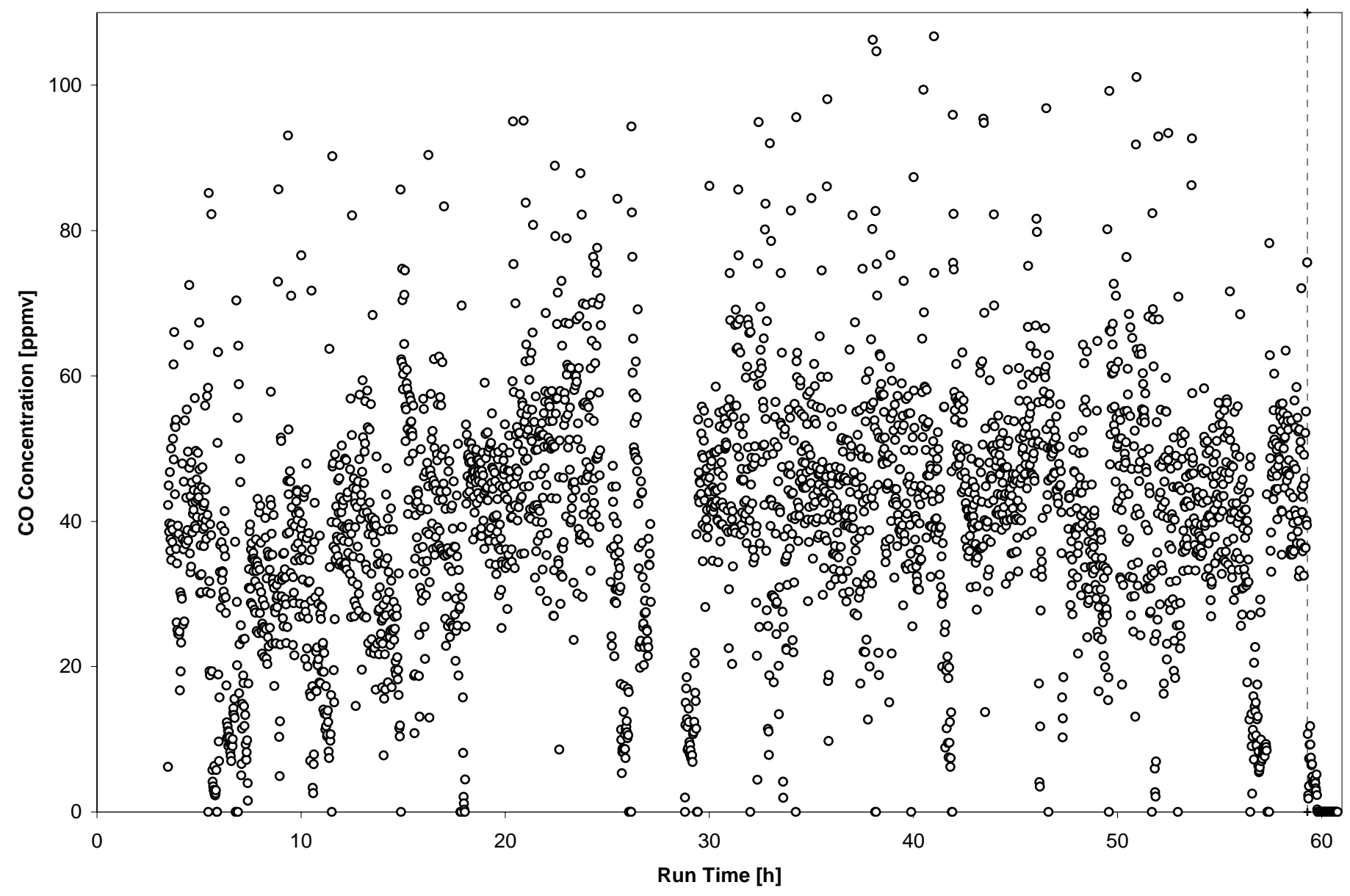

Figure 6.2.a. CO concentrations in off-gas from FTIR for the DM100 Urea and Sugar Test. 


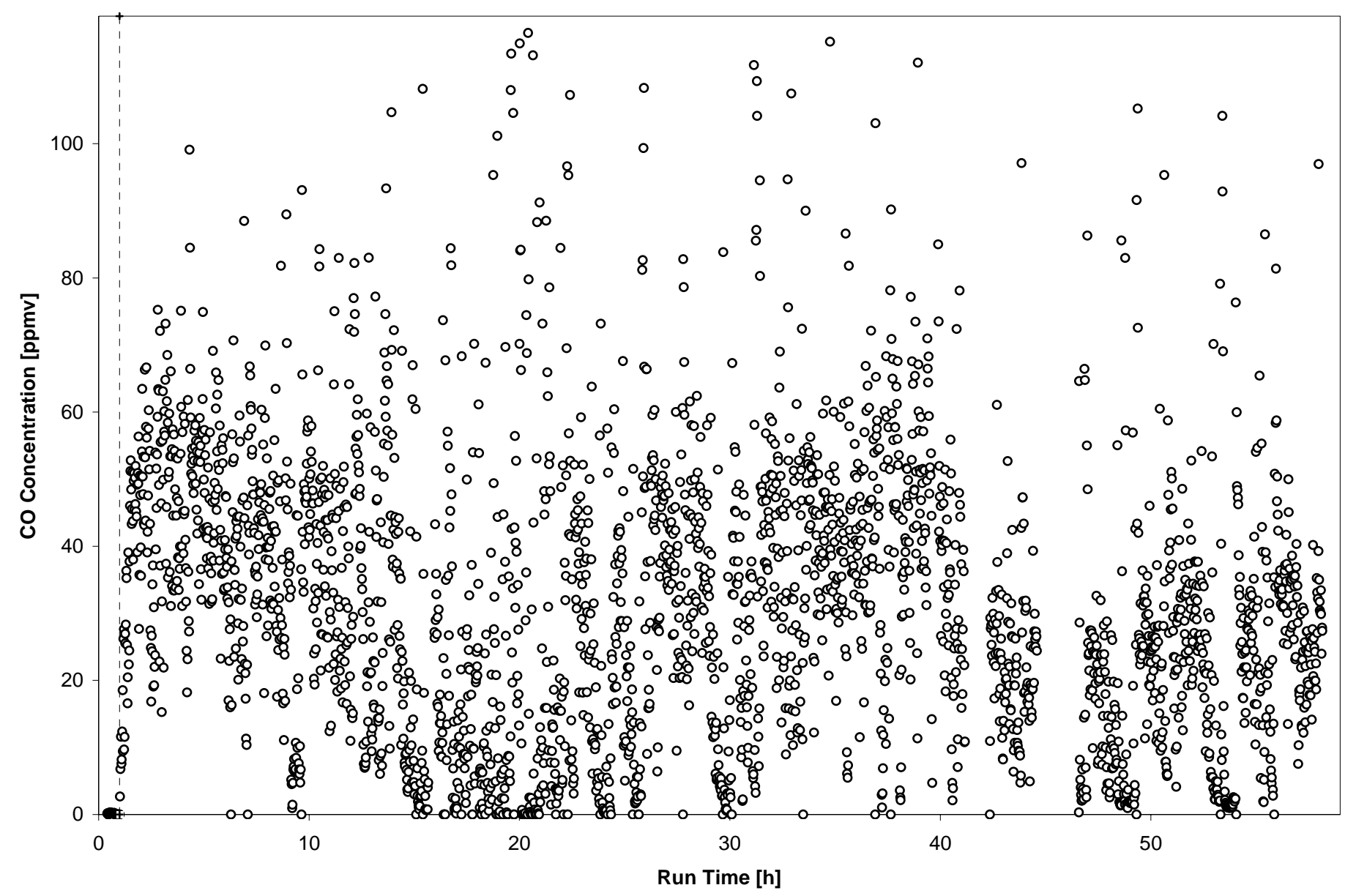

Figure 6.2.b. CO concentrations in off-gas from FTIR for the DM100 Vanadium Additive Test. 


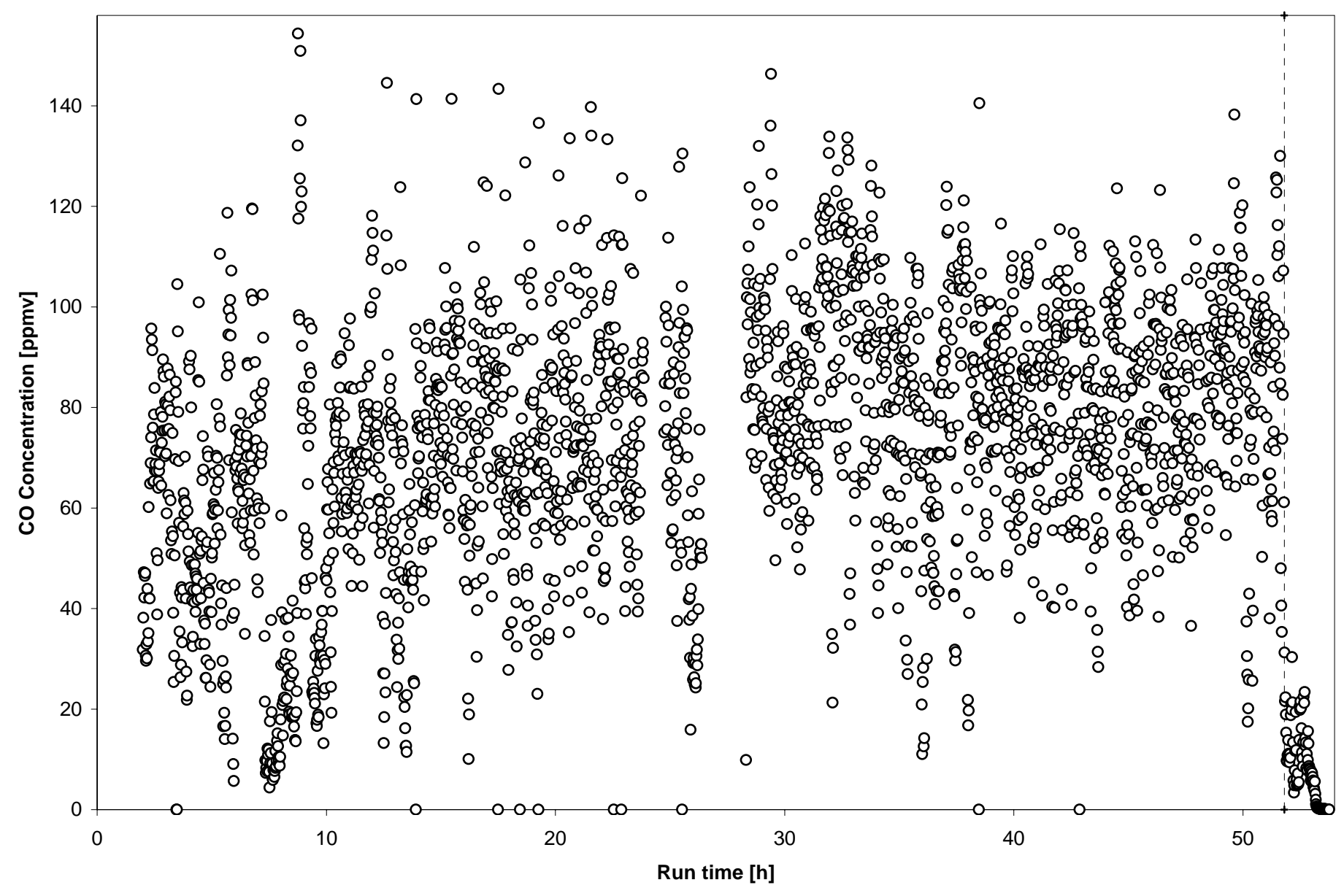

Figure 6.2.c. CO concentrations in off-gas from FTIR for the DM100 Starch and Sugar Test. 


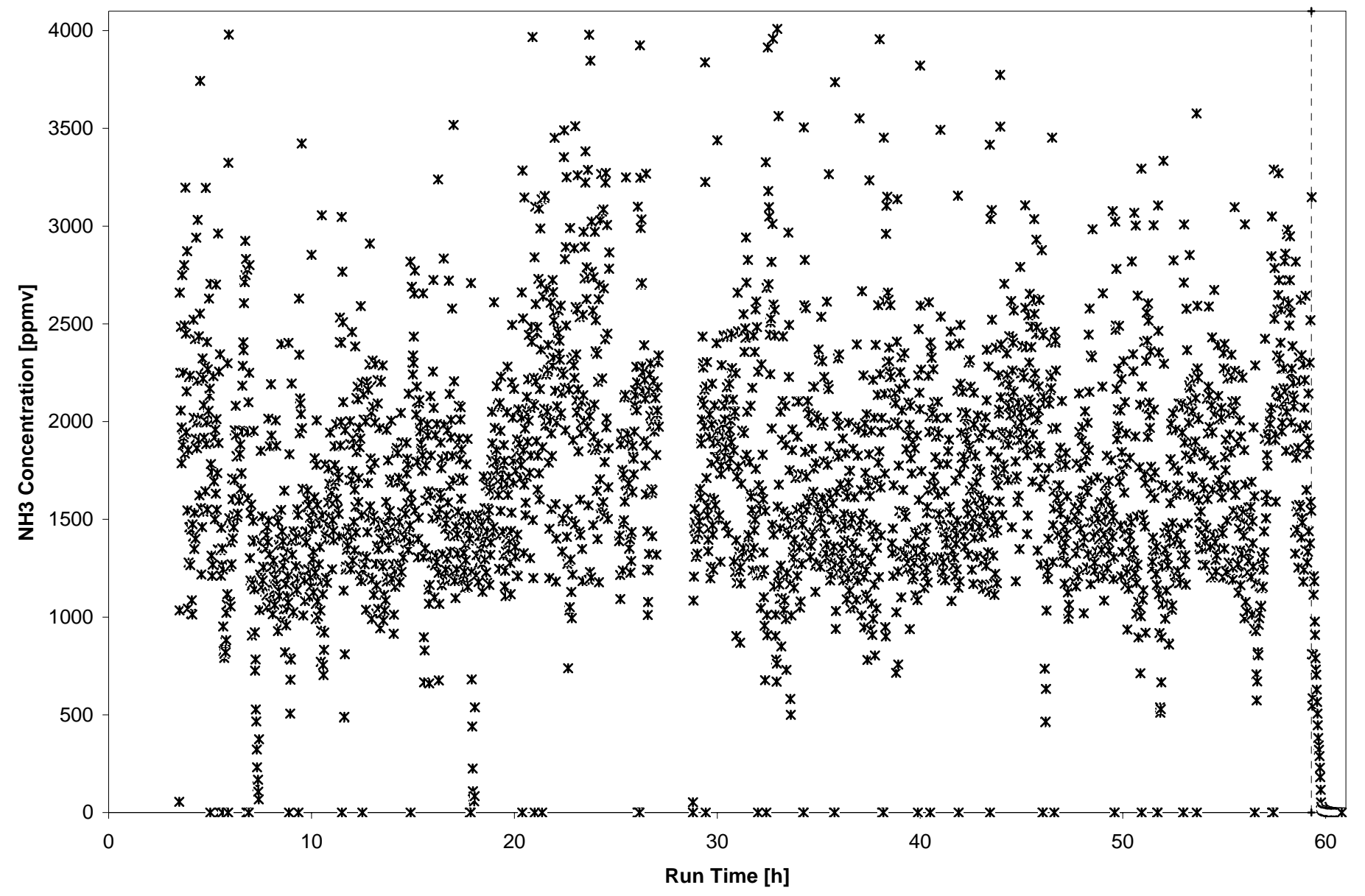

Figure 6.3.a. $\mathrm{NH}_{3}$ concentrations in off-gas from FTIR for the DM100 Urea and Sugar Test. 


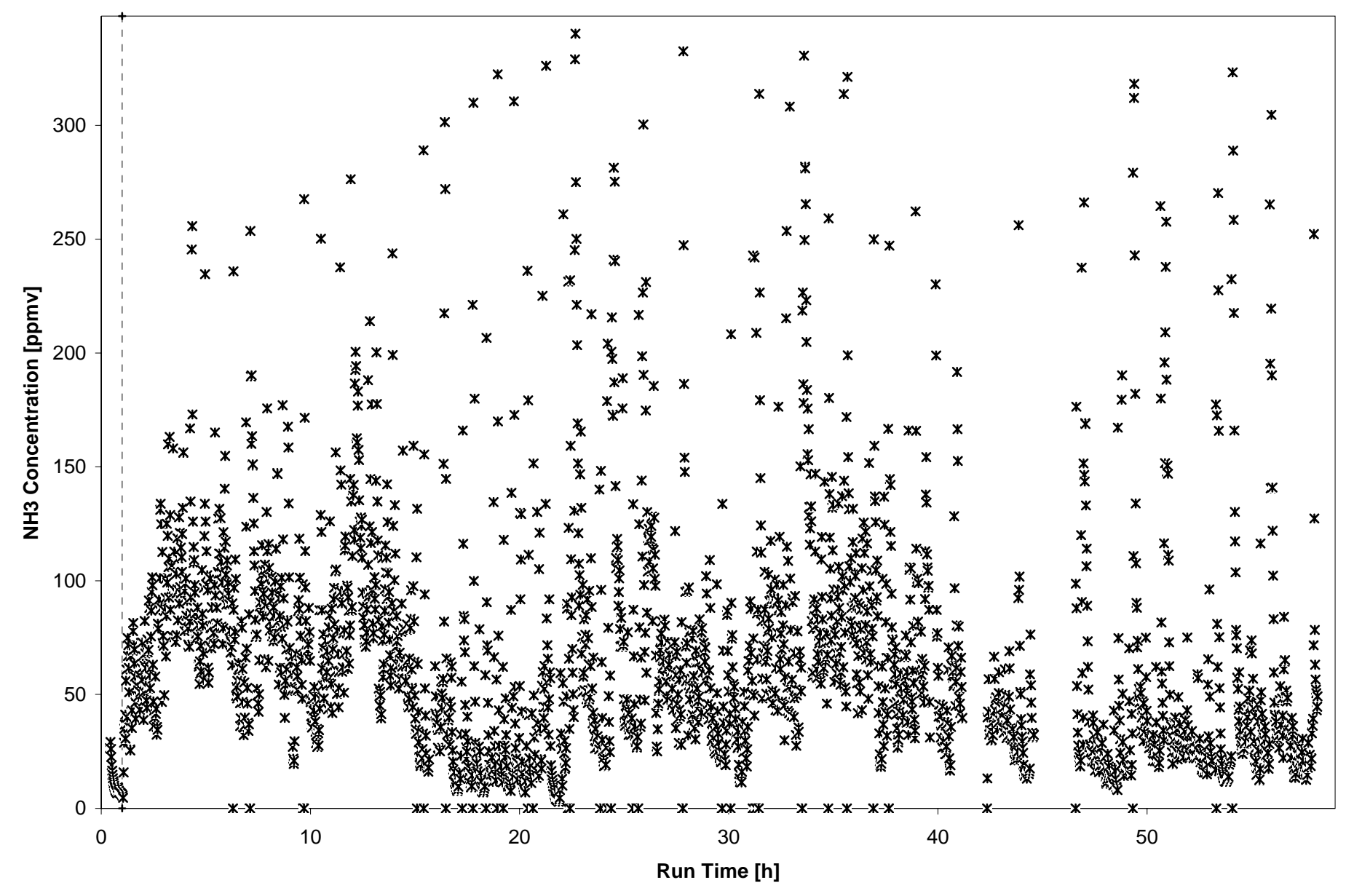

Figure 6.3.b. $\mathrm{NH}_{3}$ concentrations in off-gas from FTIR for the DM100 Vanadium Additive Test. 


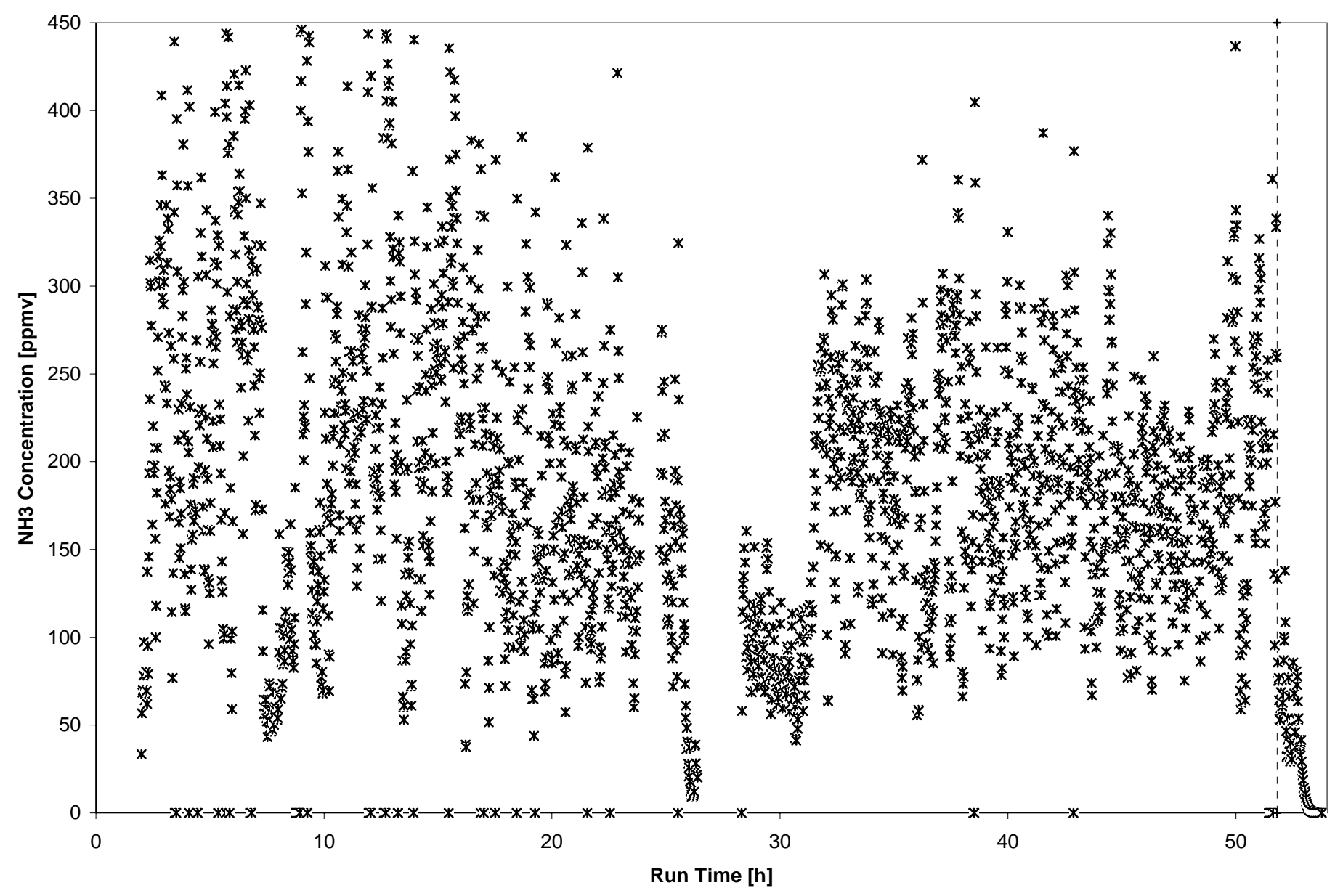

Figure 6.3.c. $\mathrm{NH}_{3}$ concentrations in off-gas from FTIR for the DM100 Starch and Sugar Test. 